\title{
12. ORGANIC GEOCHEMISTRY AND CLAY MINERALOGY OF LOWER CRETACEOUS SEDIMENTS FROM ALLISON AND RESOLUTION GUYOTS (SITES 865 AND 866), MID-PACIFIC MOUNTAINS ${ }^{1}$
}

\author{
François Baudin, ${ }^{2}$ Jean-François Deconinck, ${ }^{3}$ Reinhard F. Sachsenhofer, ${ }^{4}$ André Strasser,${ }^{5}$ and Hubert Arnaud ${ }^{6}$
}

\begin{abstract}
Clay- and organic-rich facies were deposited in Early Cretaceous shallow-water environments from both Allison (Hole 865A) and Resolution (Hole 866A) guyots in the northwestern Pacific Ocean. Together with mineralogical, sedimentological, and petrographical examinations, organic matter was characterized using Rock-Eval pyrolysis, vitrinite reflectance measurements, elemental analysis of selected kerogens, and chromatography of the saturated and unsaturated hydrocarbons.

Low to very low organic carbon content characterizes gray green pyritic claystones and most of the bioturbated clayey wackestones and packstones in Hole $865 \mathrm{~A}$, whereas organic carbon contents up to $50 \%$ are recorded in black and brown claystones. Percentages of organic carbon in Hole $866 \mathrm{~A}$ present high-amplitude variations that range from $0.1 \%$ to $34.5 \%$. As a general rule, total organic carbon contents higher than $3 \%$ are recorded in laminated limestones, algal mats, and claystones with plant debris, whereas gray limestones, sandy claystones, and green claystones have organic carbon contents lower than $0.5 \%$.

According to the hydrogen indices, $\mathrm{H} / \mathrm{C}$ ratios of kerogen concentrates, and the richness in vitrinite, the origin of organic matter is mainly terrestrial (type III) in Hole 865A. At the base of this hole, two organic-rich samples with well-preserved algal structures, high hydrogen indices, and high $\mathrm{H} / \mathrm{C}$ ratios contain type I or II organic matter. In Hole 866A, the organic matter is widely distributed between type I (algal or bacterial) and type IV (altered organic matter), according to the wide range of hydrogen indices. Laminated limestones and algal mats are related to type I or II organic matter, according to their high hydrogen indices and $\mathrm{H} / \mathrm{C}$ ratios, as well as their richness in lamalginite and bituminite. Black claystones rich in vitrinite are related to type III (terrestrial), whereas other lithologies generally contain a type IV (oxidized) organic matter.

$T_{\max }$ and vitrinite reflectance measurements, as well as biomarker abundance, suggest that the organic matter is too immature for hydrocarbon generation.

The composition of clay-mineral assemblages results from various early diagenetic, volcanic, and detrital influences that reflect the evolution of the Lower Cretaceous sedimentary environments of Allison and Resolution guyots.

Most of the sulfur in the sediment is in the form of pyrite at Hole 865A, whereas the proportion of sulfur in organic form is much more important in sediments from Hole 866A, where cyanobacterial mats predominate.

Variations in the quantity and quality of clay minerals and organic matter are strongly dependent on the lithology, as well as the paleoenvironmental evolution of the guyots. During the early history of Allison Guyot, soil-derived material, including illite-smectite mixed-layers, kaolinite, and terrestrial organic matter, were probably supplied from residual volcanic islands. This land-derived influx became less abundant upward and progressively disappeared, suggesting that the volcanic islands were definitively submerged. The clay- and marine organic-rich facies were mainly deposited during lagoonal to peritidal phases of the history of Resolution Guyot. Nevertheless, terrestrial organic matter occurs here and there, implying the existence of nearby vegetated islands.

Comparison of Aptian sediments from Hole 866A with those of DSDP Site 463 suggests that the late early Aptian Oceanic Anoxic Event, corresponding to the Selli level, may be recorded at both sites.
\end{abstract}

\section{INTRODUCTION AND GEOLOGICAL SETTING}

Two deep holes drilled during Ocean Drilling Program (ODP) Leg 143 in the Mid-Pacific Mountains (Fig. 1) penetrated the Cretaceous lagoonal facies of Allison (Hole 865A) and Resolution (Hole 866A) guyots. Both sections present thick, shallow-water carbonate caps that recorded the histories of the guyots from the submergence of the volcanic pedestal through the final drowning of the carbonate platform (Shipboard Scientific Party, 1993).

Hole 865A (Allison Guyot) penetrated $731 \mathrm{~m}$ of upper Albian shallow-water limestones that become organic-rich and clayey within

\footnotetext{
'Winterer, E.L., Sager, W.W., Firth, J.V., and Sinton, J.M. (Eds.), 1995. Proc. ODP. Sci. Results, 143: College Station, TX (Ocean Drilling Program).

${ }^{2}$ CNRS-URA 1761 et Département de Géologie Sédimentaire, Université Pierre et Marie Curie, 4 place Jussieu, 75252 Paris Cédex 05, France.

${ }^{3}$ Sédimentologie et Géodynamique and CNRS-URA 719, Université des Sciences et Technologies de Lille, 59655 Villeneuve d'Ascq Cédex, France.

${ }^{4}$ Forschungzentrum Jülichl, Institut für Erdöl und Organische Geochemie (ICG-4) Postfach 1913, Jülich D-5170, Federal Republic of Germany. (Present address: Institut für Geowissenschaften, Mining University, Leoben A-8700, Austria.)

5 Institut de Géologie, Université de Fribourg, Pérolles, CH-1700 Fribourg, Switzerland.

${ }^{6}$ Institut Dolomieu et CNRS-URA 69, 15 rue Maurice Gignoux, 38031 Grenoble Cédex, France.
}

the bottom $100 \mathrm{~m}$ (Fig. 2). Basaltic sills interlayered with limestones were recovered in the last $34 \mathrm{~m}$. Dissolution, mineralization, and filling in of cavities by Upper Cretaceous sediments are evidence of prolonged emergence at the top of the shallow-water carbonates. During the Paleogene, the guyot acquired a substantial pelagic cap (about $140 \mathrm{~m}$ ) that consists mainly of upper Paleocene and lower to mid-Eocene nannofossil and foraminiferal oozes.

Hole $866 \mathrm{~A}$ (Resolution Guyot) produced a section of $124 \mathrm{~m}$ of basalt overlain by $1620 \mathrm{~m}$ of shallow-water limestones (Fig. 2). The carbonate sequence ranges from Hauterivian to Albian in age and has a predominance of dolomitized oolitic or oncoidal facies near the bottom and cyclic, often restricted and organic-rich shallow-water facies at the top. Evidence of karstification and mineralized surfaces also is seen on the top of this carbonate edifice. The guyot is capped by a thin veneer of winnowed and reworked pelagic sediments that contain both nannofossil and foraminiferal assemblages ranging from Maastrichtian to Pliocene in age.

The purposes of this study are to describe the sedimentological, mineralogical, petrological, and geochemical characteristics of the Lower Cretaceous clay- and organic-rich facies from Holes $865 \mathrm{~A}$ and $866 \mathrm{~A}$ and to discuss the origin of the organic matter and clay minerals, as well as to reconstruct the environmental conditions that allowed the preservation of the organic matter. 


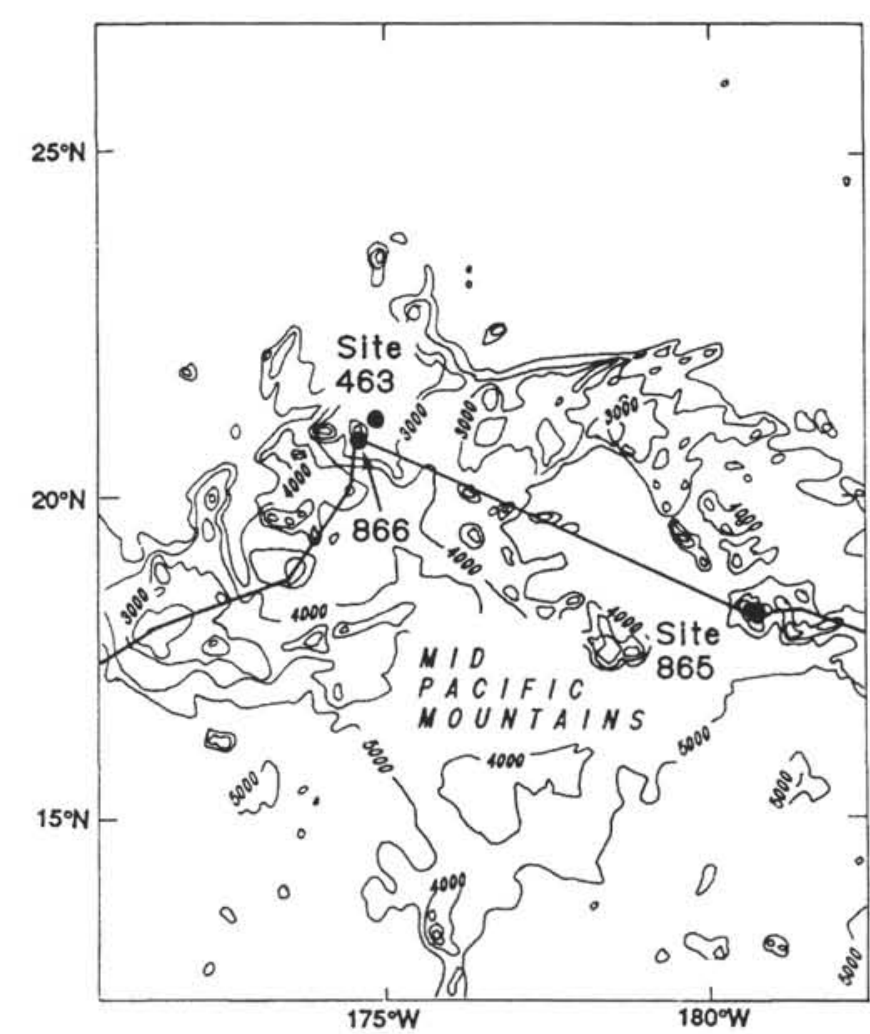

Figure 1. Bathymetric chart of the Mid-Pacific Mountains and location of Sites 865 and 866 and nearby DSDP Site 463. Bathymetric contours are shown in 1000-m intervals. Heavy line shows track of JOIDES Resolution.

\section{DESCRIPTIONS OF ORGANIC CARBON-RICH FACIES}

The 131 samples studied were selected for analysis of both sedimentological and organic geochemical characteristics at the same scale. The set of samples may be considered as representative of the various dark and clayey facies encountered in the cores.

\section{Hole 865A}

All studied samples from Hole $865 \mathrm{~A}$ are from the lower part of the recovered Albian sediments (Unit IV, Fig. 2). This unit is characterized by clayey bioclastic wackestones to packstones that contain finely dispersed carbonaceous debris. The limestones contain benthic foraminifers, ostracodes, gastropods, bivalves, sponges, and calcareous algae, and are intensely burrowed by Thalassinoides. The lowermost Subunit IVD is intruded by several basaltic sills and shows abundant pyrite associated with burrows and plant fragments. Clayey mudstones having well-preserved plant-cell structures or roots in growth position are a common minor lithology. Coaly fragments and clay layers become less abundant upward and disappear in the upper part of Subunit IVA. A coaly claystone bed occurs in Section 143-865A-90R-3 (Fig. 3), and a dark brown to black finely laminated claystone interval occurs in Section 143-865A-92R-2 (Shipboard Scientific Party, 1993). We chose 37 samples from Cores 143-865A-71R to -94R in the different lithologies, especially within dark carbonaceous facies.

\section{Hole 866A}

The organic carbon-rich facies at Hole 866A occur from Units IV to VII within the thick Barremian to middle Aptian carbonate section that caps Resolution Guyot (Shipboard Scientific Party, 1993). These consist mainly of clay- and organic-rich bioturbated mudstones (Fig. 4) and algal laminites (Fig. 5). These facies are largely dolomitized in Unit VII

Although recovery was low (15\% in average), the cored material shows well-developed meter-scale sequences in the lagoonalperitidal environment (Strasser et al., this volume). The ideal sequence starts with dark gray layers and grades up into peloidal packstones, then into algal or cyanobacterial mats. Boundaries of small sequences are commonly underlined by bird's eyes, tepee structures, and desiccation fissures. Algal laminites and clay- and organic-rich mudstones locally contain ostracodes and black peloids. Packstones and wackestones contain marine gastropods, bivalves, benthic foraminifers, and dasycladacean algae, and are commonly burrowed, suggesting an open-marine environment. Lignitic fragments, indicating terrestrial influences, occur in the section.

Ninety-four samples were collected from Cores 143-866A-50R to Core -148R. A small selection was made in oolitic grainstones from Unit V and in dolomitic grainstones from Subunit VIIC.

\section{METHODS}

\section{Petrology and Mineralogy}

The lithofacies were classified after optical descriptions of the samples, and when available, of thin sections observed in transmittedlight. More detailed investigations were also done on rock fragments with the scanning electron microscope (SEM) in two different modes, using a JEOL $840 \mathrm{~A}$. Mineral structures were observed by the secondary electron (SE) mode, and organo-mineral textures were examined in a back-scattered electron (BSE) mode. BSE imaging is particularly useful for visualizing organic matter, because a good contrast exists between organic products and the mineral matrix, owing to the low mean atomic number of organic matter (Belin, 1992).

All samples were crushed in an agate-mortar, and the carbonate content was measured using a calcimetric bomb.

The clay-mineral assemblages of the 131 samples were studied using X-ray diffraction (XRD) on oriented pastes. Clays were deflocculated by successive washing with distilled water after decarbonation of the crushed rock with $0.2 \mathrm{~N} \mathrm{HCl}$. The clay fraction (particles of less than $2 \mu \mathrm{m}$ ) was separated by sedimentation and centrifugation (Brown and Brindley, 1980; Holtzapffel, 1985). XRD patterns were obtained using a Philips PW 1730 diffractometer with $\mathrm{CuK} \alpha$ radiations and a $\mathrm{Ni}$ filter. A tube voltage of $40 \mathrm{kV}$ and a tube current of $25 \mathrm{~mA}$ were used. Three X-ray diagrams were obtained: after air drying, after ethyleneglycol solvation, and after heating at $490^{\circ} \mathrm{C}$ for $2 \mathrm{hr}$. The goniometer scanned from $2.5^{\circ}$ to $28.5^{\circ} 2 \Theta$ for air-dried and glycol-solvated conditions, and from $2.5^{\circ}$ to $14.5^{\circ} 2 \Theta$ for heating conditions. Clay minerals were identified according to the position of the (001) series of basal reflections on the three X-ray diagrams (Brown and Brindley, 1980; Moore and Reynolds, 1989). Semiquantitative estimations are based on intensity and area of the main diffraction peak of each clay-mineral (Holtzapffel, 1985). The percentages of smectite layers in illite-smectite mixed-layers (I/S) are estimated by measuring the "saddle index" (Inoue et al., 1989). The chemistry of clay minerals belonging to the illite-smectite mixed-layers group was analyzed using a CAMEBAX microprobe. This was done on selected samples that were characterized by an almost monomineral clay fraction. Differential thermal analyses (DTA) were performed on some clay fractions under Ar-gas with a SETARAM TAG 24 thermo-analyzer at a heating rate of $10^{\circ} \mathrm{Cl}$ $\mathrm{min}$. The observations by transmission electron microscopy (TEM) were performed using a JEOL $100 \mathrm{CX}$.

Organic petrological studies were performed on two whole-rock samples and seven kerogen concentrates from Hole 865A and 10 kerogen concentrates from Hole 866A. Because of the small amount of rock material, it was not possible to study whole-rock and kerogen concentrates of the same sample. Quantitative maceral evaluation was performed in white light and in fluorescence mode. Vitrinite and 
$865 \mathrm{~A}$
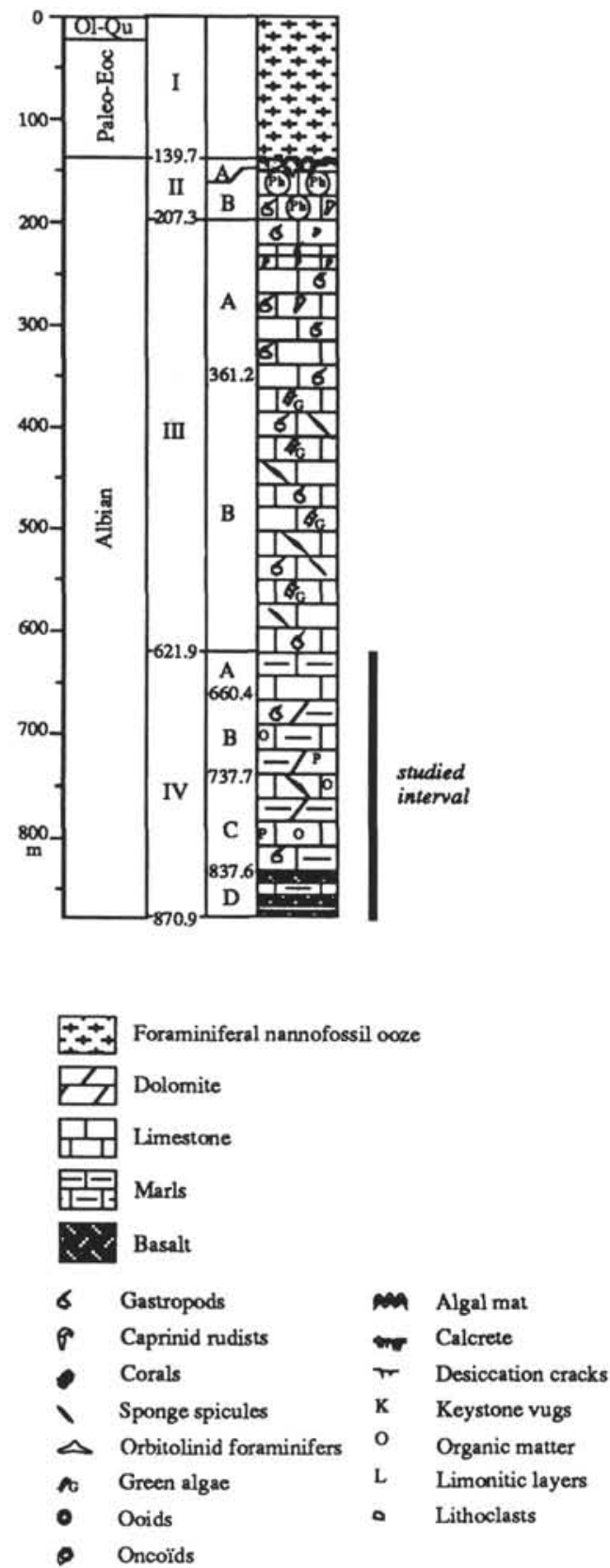

866A

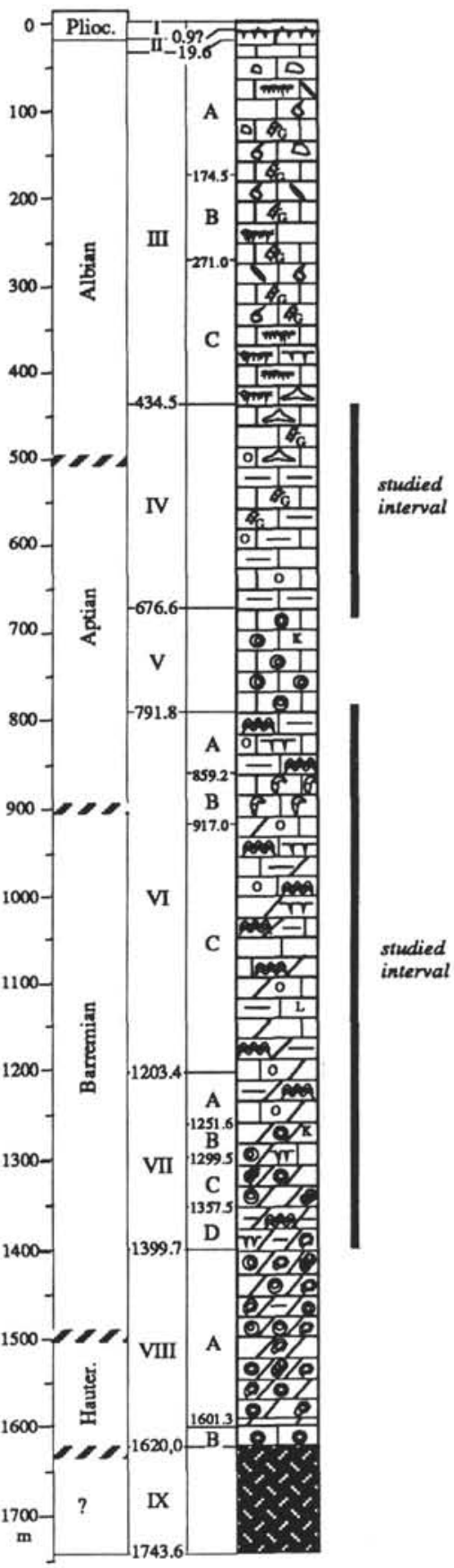

Figure 2. Schematic lithostratigraphic successions of Holes $865 \mathrm{~A}$ and $866 \mathrm{~A}$ with the studied intervals.

inertinite particles were counted using reflected light. The following liptinite macerals were recognized using a fluorescence mode:

1. Higher plant liptinites: sporinite, suberinite, cutinite, and resinite;

2. Telalginite: alginite derived from large thick-walled, unicellular or colonial algae;

3. Amalginite: alginite derived from thin-walled lamellar algae;

4. Bituminite: liptinite maceral without definite shape and having a strong affinity for degraded algae (e.g., Taylor et al., 1991). Their fluorescence intensities vary in a wide range, but are low in comparison to other liptinite macerals; and

5. Liptodetrinite: fluorescent fragments that cannot be assigned to a specific primary maceral.
For maturity assessments, vitrinite reflectance was measured under oil immersion (see Stach et al., 1982).

\section{Organic Geochemistry}

Free and potential hydrocarbons were measured by Rock-Eval pyrolysis (Espitalié et al., 1985a, 1985b, 1986) on the crushed crude rock samples. Standard notations have been used: $S_{1}$ and $S_{2}$ in milligrams of hydrocarbons (HC) per gram of rock; $T_{\max }$ expressed in ${ }^{\circ} \mathrm{C}$, and the total organic carbon (TOC) content in weight percent. The hydrogen index $\left(\mathrm{HI}=\mathrm{S}_{2} / \mathrm{TOC} \times 100\right)$ and oxygen index $\left(\mathrm{OI}=\mathrm{S}_{3} / \mathrm{TOC}\right.$ $\times 100)$ are expressed in milligrams HC per gram of TOC and milligrams $\mathrm{CO}_{2}$ per gram of TOC, respectively. To give a wider statistical 


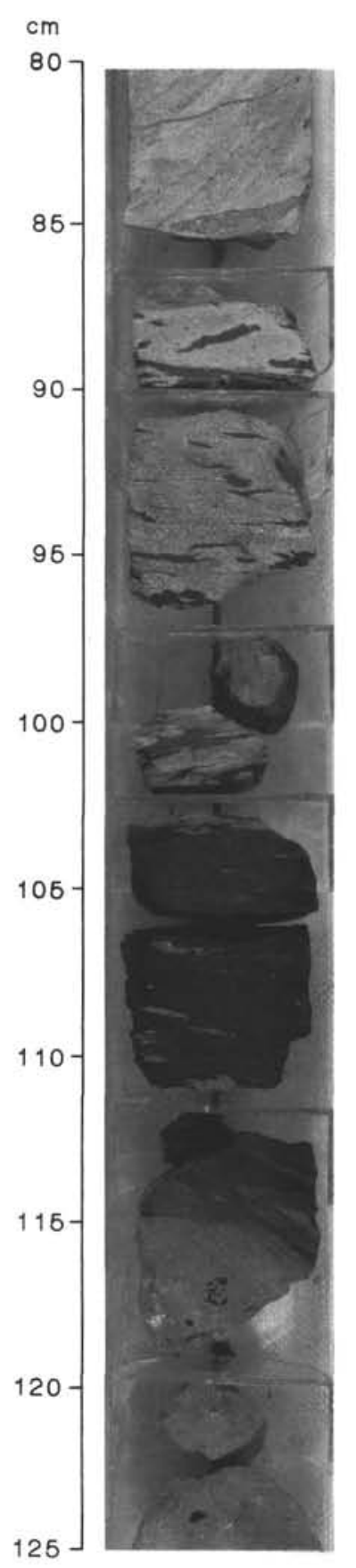

Figure 3. Photograph of Interval 143-865A-90R-3, 80-125 cm, showing coaly packstone and black claystone.

geochemical characterization of the organic material, all samples were analyzed twice.

Kerogen concentrates were extracted from 21 rock samples by $\mathrm{HCl}-\mathrm{HF}$ treatment according to the Institut Français du Pétrole standard procedure (Durand and Nicaise, 1980). Kerogen concentrates were analyzed by Rock-Eval, and their elemental compositions $(\mathrm{C}, \mathrm{H}$, $\mathrm{O}, \mathrm{N}, \mathrm{S}$, and $\mathrm{Fe}$ ) were measured using the method summarized by Durand and Monin (1980). Pyrite quantity and organic-sulfur values were calculated assuming that all iron was in the form of pyrite. Other minerals, called here "ash," were calculated taking the difference between the sum of all elements and 100. Of course, this value is approximate and includes several elements that may be present in

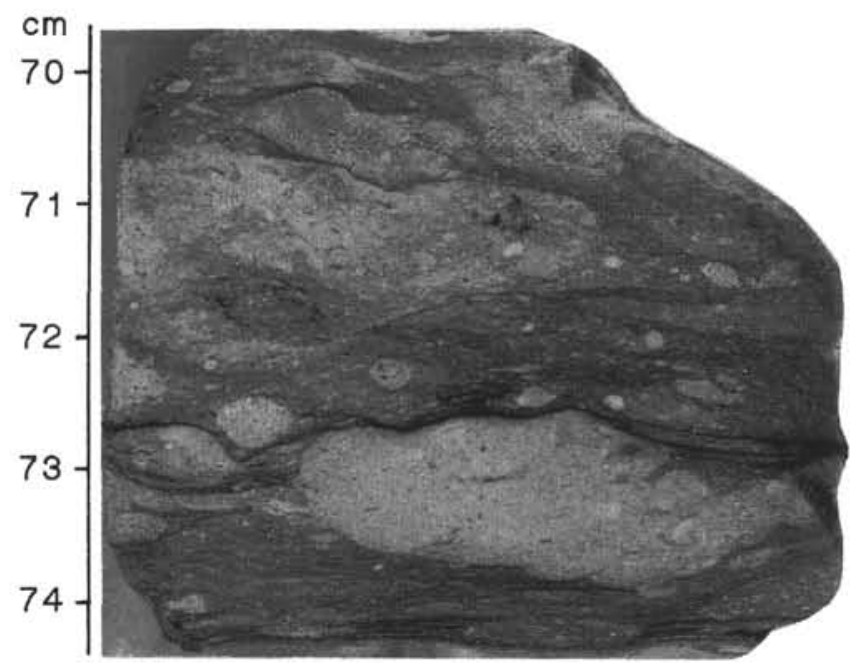

Figure 4. Bioturbated peloidal wackestone with clay- and organic-rich flakes and undulating laminites from Unit IV (Interval 143-866A-56R-1, 70-74 cm).

kerogen. Kerogen types were recognized using the classical van Krevelen diagram, which plots $\mathrm{H} / \mathrm{C}$ vs. O/C (atomic ratios).

Kerogen concentrates were extracted with dichloromethane at $60^{\circ} \mathrm{C}$ for $1 \mathrm{hr}$. The extracts, called "bitumen," were concentrated in a rotary evaporator and dried in open air. The relative proportions of bitumen are expressed as Ext/TOC in percent. All the bitumens were separated by thin-layer chromatography into saturates+unsaturates, aromatics, and $\mathrm{N}, \mathrm{S}, \mathrm{O}$-compounds. Capillary gas-chromatographic separation of the $\mathrm{C}_{15+}$ aliphatic fraction was accomplished on a VARIAN 3500 gas-chromatograph fitted with a quartz column DBI $(\phi 0.32 \mathrm{~mm} \times 30 \mathrm{~m})$.

\section{RESULTS AND DISCUSSION}

\section{Petrography}

\section{Hole $865 A$}

Five thin sections and two rock fragments examined with SEM allow us to roughly characterize the microfacies and nannofacies of carbon-rich facies from Subunits IVC and IVD.

The main microfacies are wackestones, more or less rich in detrital quartz and clay minerals. Ostracodes, bivalve fragments, and gastropods are the main bioclasts. Pyrite is ubiquitous and locally abundant (Sample 143-865A-94R-3, 33-34 cm). Organic particles are present in all samples and show two different populations. One corresponds to black particles that reach a length of $0.5 \mathrm{~cm}$; these are related to higher plant debris. Some of the fragments are partly pyritic. Microcracks are frequent in these plant fragments, which suggests a strong alteration, probably subaerial, before burial (Pl. 1, Fig. 1). The other population is generally smaller (less than $100 \mu \mathrm{m}$ ) and is light brown to intense yellow or dark red. Samples from Section 143-865A-92R-2 contain a high proportion of yellow particles that reach a width of 300 $\mu \mathrm{m}$, which suggests a concentration of algae (Pl. 1, Fig. 2).

SEM images show clear higher-plant cell structures and pyritized casts of tracheids, as well as fossilized bordered pits. Such impregnations of iron sulfides generally disturb the original structures, but these latter are here easily recognizable.

\section{Hole $866 \mathrm{~A}$}

Most studied samples appear as clayey mudstones, with ostracodes, foraminifers, and small organic particles or organic laminae. Such microfacies mainly characterize the early to middle Aptian Unit IV. Porous wackestone and packstone with small ooids, peloids, for- 
aminifers, and ostracodes predominate in Unit VI. These generally contain yellow to pale brown laminae.

Thin sections of organic carbon-rich samples display rare ligneous debris and two populations of algae. One is fine, dispersed, and dark red to brown (Pl. 1, Fig. 3). The other is elongate, yellow, and constitutes a more or less dense network of laminae (Pl. 1, Fig. 4). Clay and organic matter, which are closely associated, appear dark in transmitted light. In the absence of clay minerals, organic matter is dark yellow to yellow. Pyrite is dispersed as very fine grains within the yellow laminae, but locally presents $250-\mu \mathrm{m}$-sized euhedral habits (Sample 143-866A-71R-1, 102-104 cm). Cuticles and coaly fragments with microcracks are locally abundant (Sample 143-866A$86 \mathrm{R}-3,47-49 \mathrm{~cm})$.

SEM images provide a detailed picture of the sediment and particularly enabled us to distinguish between organic matter and minerals through use of the BSE mode. Many organic laminae have wavy shapes and present a 10 - to $100-\mu \mathrm{m}$ thickness, with a mean value of 30 $\mu \mathrm{m}$. Single laminae in thin section under SEM display a succession of fine $(5-10 \mu \mathrm{m})$ and continuous laminae (Pl. 1, Fig. 5). Some isolated crystals mark the limits between elemental laminae and may correspond to an interruption in the growth of the algal or bacterial mat. The contact between carbonate and organic lamina is generally sharp, but alteration of organic material is evident in some samples (PI. 1, 6). Isolated coccoliths are frequent in Unit IV in the carbonate layers between algal laminae, but their occurrence cannot be considered as an evidence of pelagic environment (Noël et al., 1993). Rather, these imply oxygenated surface water with repeated access to an openmarine environment.

\section{Carbonates and Clay Minerals}

\section{Hole $865 A$}

Carbonate content of Unit IV is characterized by high-amplitude variations that range from $0 \%$ to $93 \%$ (Table 1), with a general trend from $0 \%$ at the bottom to $70 \%$, on average, at the top (Fig. 6). The gray wackestone and clayey packstone facies, both intensely bioturbated, have $60 \%$ to $90 \%$ carbonate content vs. $25 \%$ to $60 \%$ for facies without bioturbation. The carbonate content for the coaly claystone facies of Subunits IVC and IVD is less than $20 \%$, and many samples show zero values.

The clay fraction of the 39 studied samples from Unit IV is composed of variable amounts of I/S, illite, kaolinite, and berthierine. Each subunit exhibits a distinct clay mineralogy (Fig. 7).

Sediments from Subunit IVD, which consist of clayey bioclastic limestones intruded with basaltic sills, display a clay fraction composed almost entirely of random I/S that occurs together with traces of kaolinite (Fig. 7). According to the position of the (001) reflections and by comparison with XRD patterns published by Reynolds (1980), the I/S layers contain about $70 \%$ smectite. This is confirmed by the measurement of the saddle index, which is from 0.3 to 0.5 . DTA curves from the clay fraction of two samples (Fig. 8) indicate a well-expressed first endotherm between $100^{\circ}$ and $150^{\circ} \mathrm{C}$ that corresponds to dehydration. The second endotherm (dehydroxylation) occurs on both curves at $500^{\circ} \mathrm{C}$ and the third reaction, corresponding to the endo-exothermic reaction (destabilization/recrystallization), occurs between $850^{\circ}$ and $950^{\circ} \mathrm{C}$. The shape of this latter curve is typical of Cheto (Mg-rich) montmorillonite (Chantret et al., 1971; Paterson and Swaffield, 1987). TEM indicates a fleecy shape to the I/S particles. The clay fraction of sediments from Subunit IVC consists of a mixture of illite, I/S, kaolinite, and berthierine. The identification of berthierine is difficult because the 001 reflection of this mineral (7.04-7.05 $\AA$; Bailey, 1980) is near the 001 reflection of kaolinite $(7.14 \AA)$. The relatively important width of the peak at 7.1 $\AA$ (Fig. 9) is unusual for sedimentary kaolinite, which generally is well-crystallized and displays sharp peaks. This suggests the presence of another 1:1 layer silicate (Fig. 9). More convincing is the occurrence of the reflection between 3.5 and $3.55 \AA$ (Sample $143-865 \mathrm{~A}-86 \mathrm{R}-3,51-52 \mathrm{~cm}$ ), which is also commonly expressed by a

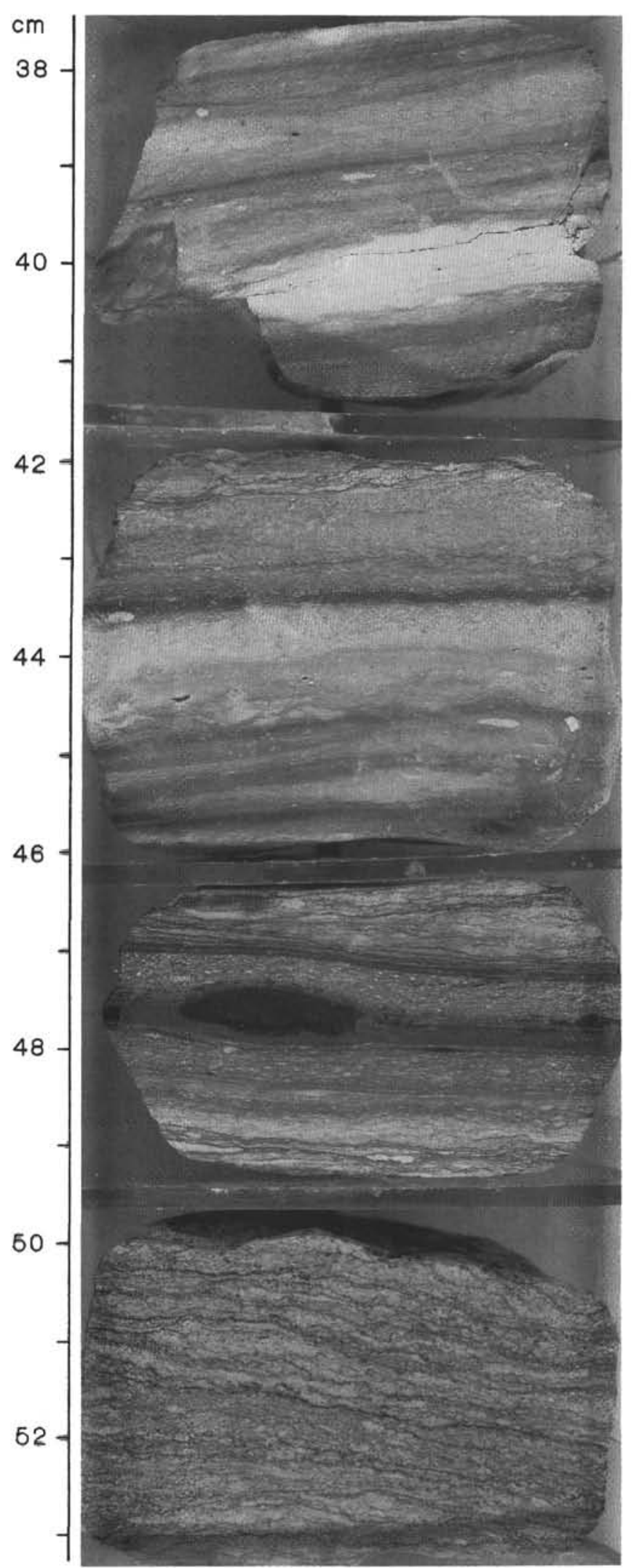

Figure 5. Common lithologies in Unit VI: finely laminated algal or cyanobacterial mats at the bottom of the photograph (Interval 143-866A-85R-2, 50-53 $\mathrm{cm}$; age: Aptian) pass upward into greenish-gray to dark gray millimeter-laminated clay mudstone with lignitic debris (Sample 143-866A-85R-2, 47-49 cm) and then to light-colored wackestone (Interval 143-866A-85R-2, 38-46 cm). 
Table 1. Rock-Eval data of samples from Holes $865 \mathrm{~A}$ and $866 \mathrm{~A}$.

\begin{tabular}{|c|c|c|c|c|c|c|c|c|c|}
\hline $\begin{array}{l}\text { Core, section, } \\
\text { interval }(\mathrm{cm})\end{array}$ & $\begin{array}{l}\text { Depth } \\
\text { (mbsf) }\end{array}$ & Lithology & $\begin{array}{c}\mathrm{CaCO}_{3} \\
(\%)\end{array}$ & $\begin{array}{l}\text { TOC } \\
(\%)\end{array}$ & $\begin{array}{l}T_{\max } \\
\left({ }^{\circ} \mathrm{C}\right)\end{array}$ & $\mathrm{S}_{1}$ & $\mathrm{~S}_{2}$ & HI & OI \\
\hline $143-865 \mathrm{~A}-$ & & & & & & & & & \\
\hline $71 \mathrm{R}-\mathrm{CC}, 16-17$ & 650.96 & Gray wackestone & 90 & 0.27 & 425 & 0.01 & 0.18 & 67 & 207 \\
\hline $73 \mathrm{R}-1,23-24$ & 670.33 & Clayey wackestone & 32 & 1.01 & 426 & 0.05 & 0.88 & 88 & 118 \\
\hline $74 \mathrm{R}-1,110-112$ & 680.80 & Dark gray clayey wackestone & 68 & 1.14 & 432 & 0.06 & 2.28 & 200 & 128 \\
\hline $82 \mathrm{R}-1,19-20$ & 757.29 & Grayish clayey wackestone & 35 & 0.27 & $426^{*}$ & & 0.01 & 6* & $259^{*}$ \\
\hline $82 \mathrm{R}-2,41-43$ & 758.44 & Gray wackestone & 71 & 0.75 & 425 & 0.03 & 0.76 & 101 & 163 \\
\hline $85 \mathrm{R}-1,123-124$ & 787.43 & Bioturbated wackestone & 81 & 0.69 & 422 & & 0.23 & 34 & 151 \\
\hline $85 \mathrm{R}-2,3-4$ & 787.47 & Bioturbated wackestone & 71 & 1.03 & 423 & 0.01 & 0.36 & 34 & 139 \\
\hline $85 \mathrm{R}-2,43-44$ & 787.87 & Bioturbated wackestone & 82 & 0.39 & $413^{*}$ & & 0.09 & 22 & 206 \\
\hline $86 \mathrm{R}-3,51-52$ & 799.27 & Bioturbated wackestone & 77 & 0.39 & $366^{*}$ & & 0.01 & $3 *$ & $327^{*}$ \\
\hline $86 \mathrm{R}-3,70-71$ & 799.46 & Clayey packstone & 87 & 0.59 & $394^{*}$ & & 0.09 & $15^{*}$ & $103 *$ \\
\hline $86 \mathrm{R}-3,72-73$ & 799.48 & Clayey packstone & 93 & 0.29 & 427 & & 0.41 & 143 & 184 \\
\hline $87 \mathrm{R}-1,89-92$ & 806.29 & Clayey bioturbated packstone & 90 & 0.43 & 427 & & 0.51 & 120 & 180 \\
\hline $87 \mathrm{R}-2,81-82$ & 807.61 & Clayey bioturbated packstone & 82 & 0.58 & $414^{*}$ & & 0.06 & $10^{*}$ & $156^{*}$ \\
\hline $87 \mathrm{R}-2,134-137$ & 808.14 & Clayey bioturbated packstone & 83 & 0.44 & $416^{*}$ & & 0.09 & $21^{*}$ & $214^{*}$ \\
\hline $88 \mathrm{R}-1,57-59$ & 815.67 & Clayey bioturbated packstone & 92 & 0.24 & & & & & \\
\hline $88 \mathrm{R}-2,120-123$ & 817.75 & Clayey bioturbated packstone & 65 & 0.22 & & & & & \\
\hline $89 \mathrm{R}-2,2-4$ & 826.19 & Dark brown wackestone & 42 & 0.17 & & & & & \\
\hline $89 \mathrm{R}-2,110-115$ & 827.27 & Dark brown wackestone & 24 & 0.15 & & & & & \\
\hline $89 \mathrm{R}-3,33-36$ & 827.87 & Coaly claystone & 0 & 0.91 & 418 & 0.01 & 0.49 & 54 & 159 \\
\hline $89 R-3,65-70$ & 828.19 & Dark brown wackestone & 46 & 0.26 & $38 *$ & & 0.01 & $4 *$ & $635^{*}$ \\
\hline $89 R-6,11-15$ & 831.48 & Black carbonaceous mudstone & 17 & 6.39 & 417 & 0.09 & 1.87 & 29 & 68 \\
\hline $90 \mathrm{R}-1,110-111$ & 832.90 & Dark gray clayey packstone & 56 & 3.64 & 427 & 0.07 & 3.32 & 91 & 74 \\
\hline $90 \mathrm{R}-2,33-34$ & 833.27 & Clayey bioturbated packstone & 66 & 1.15 & 432 & & 0.78 & 68 & 160 \\
\hline $90 \mathrm{R}-3,12-13$ & 834.36 & Dark gray clayey packstone & 56 & 2.28 & 425 & 0.02 & 0.84 & 37 & 64 \\
\hline 90R-3, 37-38 & 834.61 & Black claystone & nd & 34.65 & 391 & 0.93 & 7.14 & 21 & 65 \\
\hline $90 \mathrm{R}-3,77-78$ & 835.01 & Packstone with wood fragments & 86 & 0.82 & 433 & 0.01 & 0.47 & 57 & 160 \\
\hline $90 \mathrm{R}-3,95-96$ & 835.19 & Coaly clayey packstone & 56 & 13.45 & 409 & 2.28 & 19.34 & 144 & 83 \\
\hline $90 \mathrm{R}-3,110-111$ & 835.34 & Coaly claystone & 0 & 50.60 & 412 & 1.60 & 21.34 & 42 & 59 \\
\hline $90 \mathrm{R}-3,112-113$ & 835.36 & Coaly claystone & 0 & 14.81 & 411 & 0.28 & 6.12 & 41 & 65 \\
\hline $90 \mathrm{R}-3,131-132$ & 835.55 & Coaly claystone & 0 & 5.01 & 390 & 0.25 & 1.04 & 21 & 125 \\
\hline $91 \mathrm{R}-5,130-132$ & 848.06 & Gray bioturbated wackestone & nd & 7.08 & 430 & 0.55 & 51.62 & 730 & 29 \\
\hline $92 \mathrm{R}-2,44-47$ & 849.07 & Brown claystone & 0 & 8.62 & 432 & 0.27 & 20.12 & 234 & 53 \\
\hline $92 \mathrm{R}-2,58-60$ & 849.21 & Black claystone & 0 & 31.11 & 421 & 2.49 & 184.03 & 592 & 25 \\
\hline $92 \mathrm{R}-2,62-63$ & 849.25 & Black claystone with pyrite & 0 & 0.23 & & & & & \\
\hline $92 \mathrm{R}-2,68-70$ & 849.31 & Gray greenish claystone with pyrite & 0 & 0.09 & & & & & \\
\hline $92 \mathrm{R}-2,75-77$ & 849.38 & Gray greenish claystone with pyrite & 0 & 0.11 & & & & & \\
\hline $94 \mathrm{R}-3,72-73$ & 866.62 & Bioturbated clayey limestone & 66 & 0.42 & 424 & & 0.09 & 22 & 160 \\
\hline $143-866 \mathrm{~A}-$ & & & & & & & & & \\
\hline 50R-CC, $31-32$ & 454.01 & White limestone with black laminae & 71 & 8.38 & 412 & 2.26 & 33.53 & 400 & 47 \\
\hline $55 \mathrm{R}-\mathrm{CC}, 1-2$ & 501.91 & Gray limestone & 93 & 0.10 & & & & & \\
\hline $56 \mathrm{R}-1,20-21$ & 511.80 & Gray limestone with black laminae & 98 & 1.46 & 426 & 0.35 & 7.25 & 498 & 69 \\
\hline $56 \mathrm{R}-1,42-43$ & 512.02 & White limestone with black laminae & 71 & 4.08 & 405 & 2.05 & 23.57 & 578 & 40 \\
\hline $56 \mathrm{R}-1,45-46$ & 512.05 & Gray limestone with laminae & 74 & 1.38 & 425 & 0.18 & 4.39 & 317 & 131 \\
\hline $56 \mathrm{R}-1,73-74$ & 512.33 & Gray limestone with black laminae & 66 & 3.13 & 396 & 1.82 & 18.78 & 600 & 47 \\
\hline 57R-1, 33-36 & 521.63 & Algal mat with black laminae & 95 & 0.84 & 422 & 0.56 & 5.17 & 619 & 68 \\
\hline $58 \mathrm{R}-1,91-93$ & 531.91 & Gray limestone with laminae & 83 & 4.18 & 425 & 1.05 & 17.74 & 425 & 69 \\
\hline 58R-1, $98-99$ & 531.98 & Algal mat & 97 & 1.20 & 420 & 0.94 & 7.62 & 635 & 65 \\
\hline $60 \mathrm{R}-1,63-64$ & 550.93 & Gray limestone with laminae & 86 & 0.58 & 427 & 0.06 & 1.61 & 274 & 200 \\
\hline $62 \mathrm{R}-1,116-118$ & 570.76 & White limestone & 90 & 3.10 & 415 & 2.54 & 22.47 & 725 & 49 \\
\hline $62 R-2,37-40$ & 571.47 & Dark gray argillaceous limestone & 82 & 1.24 & 427 & 0.25 & 5.66 & 458 & 91 \\
\hline $62 \mathrm{R}-2,40-41$ & 571.50 & Dark gray clayey limestone & 84 & 0.28 & 428 & 0.01 & 0.34 & 121 & 463 \\
\hline $63 R-2,43-45$ & 581.23 & Algal mat with black laminae & 97 & 0.86 & 415 & 0.61 & 5.26 & 615 & 79 \\
\hline $63 \mathrm{R}-2,93-94$ & 581.73 & Sandy limestone with plant debris & 93 & 0.89 & 430 & 0.11 & 2.82 & 317 & 112 \\
\hline $63 \mathrm{R}-2,109-111$ & 581.89 & Sandy limestone with plant debris & nd & 4.54 & 420 & 1.04 & 9.68 & 213 & 74 \\
\hline $65 R-1,143-144$ & 600.03 & Algal mat with black laminae & 87 & 0.80 & 434 & 0.03 & 2.09 & 263 & 142 \\
\hline $66 \mathrm{R}-1,18-20$ & 608.48 & Beige algal mat & 99 & 0.18 & & & & & \\
\hline $70 \mathrm{R}-1,19-20$ & 647.09 & Gray limestone with laminae & 85 & 0.28 & $403^{*}$ & & 0.06 & $23^{*}$ & $311^{*}$ \\
\hline $71 \mathrm{R}-2,67-68$ & 658.45 & Dark green claystone & 64 & 0.43 & $375^{*}$ & 0.01 & 0.06 & $14^{*}$ & $314^{*}$ \\
\hline $71 \mathrm{R}-2,74-75$ & 658.52 & Green claystone & 0 & 0.14 & & & & & \\
\hline $71 \mathrm{R}-2,100-101$ & 658.78 & Algal mat with black laminae & 90 & 1.90 & 420 & 1.32 & 12.84 & 676 & 49 \\
\hline $72 \mathrm{R}-1,60-61$ & 666.80 & Gray limestone with green flakes & 74 & 0.22 & & & & & \\
\hline $73 \mathrm{R}-1,42-43$ & 676.22 & Light gray limestone & 87 & 0.57 & 426 & 0.03 & 0.99 & 174 & 175 \\
\hline $74 \mathrm{R}-2,74-75$ & 687.52 & Dark sandy grainstone & 92 & 0.12 & & & & & \\
\hline $75 \mathrm{R}-1,67-68$ & 695.77 & Dark sandy grainstone & 94 & 0.12 & & & & & \\
\hline $85 R-3,47-49$ & 795.22 & Algal mat with black laminae & 31 & 34.47 & 387 & 5.39 & 50.36 & 146 & 53 \\
\hline $85 R-3,50-52$ & 795.25 & Algal mat with black laminae & nd & 3.24 & 398 & 2.29 & 22.22 & 686 & 35 \\
\hline $86 \mathrm{R}-1,143-145$ & 802.93 & Gray limestone with black level & 79 & 4.98 & 425 & 1.97 & 35.83 & 720 & 42 \\
\hline $86 \mathrm{R}-2,111-113$ & 804.11 & Gray limestone with black level & nd & 7.41 & 418 & 5.93 & 58.17 & 784 & 36 \\
\hline $88 \mathrm{R}-1,29-31$ & 821.19 & Algal mat with black laminae & 7 & 0.37 & 551 & 0.01 & 0.33 & 88 & 265 \\
\hline $88 \mathrm{R}-1,56-58$ & 821.46 & Algal mat with black laminae & 66 & 3.64 & 413 & 0.84 & 14.18 & 390 & 48 \\
\hline $88 \mathrm{R}-1,140-142$ & 822.30 & Black claystone & 28 & 0.36 & $367^{*}$ & 0.01 & 0.05 & $1 *$ & $19 *$ \\
\hline $89 \mathrm{R}-1,92-93$ & 831.52 & Dark gray claystone & 28 & 0.49 & $421 *$ & & 0.05 & $10^{*}$ & $31^{*}$ \\
\hline $89 \mathrm{R}-1,94-95$ & 831.54 & Dark gray claystone with plant debris & 15 & 1.04 & 419 & 0.04 & 0.96 & 92 & 177 \\
\hline $89 \mathrm{R}-1,96-97$ & 831.56 & Dark gray claystone with plant debris & 16 & 2.33 & 419 & 0.04 & 1.59 & 68 & 69 \\
\hline $89 \mathrm{R}-1,97-98$ & 831.57 & Black claystone with plant debris & 25 & 14.38 & 422 & 0.39 & 18.72 & 130 & 39 \\
\hline $89 \mathrm{R}-1,98-99$ & 831.58 & Algal mat with black laminae & 87 & 4.70 & 423 & 0.57 & 14.97 & 318 & 51 \\
\hline $91 R-1,10-11$ & 849.60 & Dark green laminated limestone & 31 & 0.28 & & & & & \\
\hline $91 \mathrm{R}-1,11-13$ & 849.61 & Black laminated limestone & 45 & 0.22 & & & & & \\
\hline 91R-I, 13-14 & 849.63 & Black laminated limestone & 52 & 0.33 & & & & & \\
\hline $91 \mathrm{R}-1,30-31$ & 849.80 & Algal mat with black laminae & 80 & 0.87 & 422 & 0.03 & 0.77 & 88 & 164 \\
\hline $96 \mathrm{R}-1,26-28$ & 897.96 & Algal mat with black laminae & 90 & 0.44 & 417 & 0.01 & 0.25 & 59 & 163 \\
\hline 98R-1, 96-98 & 917.96 & Algal mat with black laminae & 82 & 1.24 & 430 & 0.08 & 3.41 & 275 & 102 \\
\hline $98 \mathrm{R}-2,37-38$ & 918.87 & Algal mat with black laminae & 72 & 1.91 & 431 & 0.13 & 3.58 & 187 & 83 \\
\hline $99 \mathrm{R}-1,124-125$ & 925.14 & Algal mat with black laminae & 83 & 1.46 & 430 & 0.05 & 4.41 & 302 & 107 \\
\hline $100 \mathrm{R}-1,49-50$ & 933.89 & Black argillaceous laminated limestone & 64 & 0.80 & 413 & 0.00 & 0.25 & 31 & 155 \\
\hline $102 R-2,13-14$ & 954.33 & Algal mat with black laminae & 74 & 2.76 & 427 & 0.16 & 9.07 & 328 & 66 \\
\hline
\end{tabular}


Table 1 (continued).

\begin{tabular}{|c|c|c|c|c|c|c|c|c|c|}
\hline $\begin{array}{l}\text { Core, section, } \\
\text { interval }(\mathrm{cm})\end{array}$ & $\begin{array}{l}\text { Depth } \\
\text { (mbsf) }\end{array}$ & Lithology & $\begin{array}{c}\mathrm{CaCO}_{3} \\
(\%)\end{array}$ & $\begin{array}{l}\text { TOC } \\
(\%)\end{array}$ & $\begin{array}{l}T_{\max } \\
\left({ }^{\circ} \mathrm{C}\right)\end{array}$ & $\mathrm{S}_{1}$ & $\mathrm{~S}_{2}$ & HI & OI \\
\hline $104 \mathrm{R}-1,26-27$ & 971.96 & Black laminated limestone & 91 & 1.63 & 430 & 0.31 & 11.8 & 721 & 60 \\
\hline $105 \mathrm{R}-1,104-106$ & 982.34 & Algal mat with black laminae & 57 & 1.20 & 428 & 0.04 & 1.45 & 120 & 116 \\
\hline $106 \mathrm{R}-1,75-77$ & 991.65 & Dark green claystone & 28 & 0.63 & 418 & 0.03 & 0.64 & 101 & 181 \\
\hline $108 \mathrm{R}-1,33-35$ & 1010.53 & Black ang illaceous laminated limestone & 74 & 3.90 & 426 & 0.49 & 19.85 & 510 & 45 \\
\hline $109 \mathrm{R}-1,6-7$ & 1019.96 & Black argillaceous laminated limestone & 50 & 1.54 & 429 & 0.05 & 1.62 & 105 & 98 \\
\hline $109 \mathrm{R}-1,62-63$ & 1020.52 & Black laminated limestone & 48 & 1.04 & 418 & 0.03 & 0.58 & 56 & 100 \\
\hline $110 \mathrm{R}-1,89-90$ & 1030.49 & Black laminated limestone & 68 & 5.01 & 422 & 0.58 & 19.98 & 399 & 40 \\
\hline $110 \mathrm{R}-2,36-37$ & 1031.40 & Black laminated limestone & 50 & 1.13 & 423 & 0.04 & 1.13 & 100 & 106 \\
\hline $110 \mathrm{R}-2,88-90$ & 1031.92 & Black argillaceous laminated limestone & 79 & 1.11 & 431 & 0.14 & 4.80 & 432 & 127 \\
\hline $110 \mathrm{R}-2,105-106$ & 1032.09 & Gray limestone & 70 & 0.95 & 431 & 0.06 & 1.94 & 205 & 127 \\
\hline $110 \mathrm{R}-2,113-115$ & 1032.17 & Limestone with black laminae & 52 & 2.79 & 429 & 0.37 & 10.04 & 360 & 47 \\
\hline $111 \mathrm{R}-1,86-87$ & 1040.16 & Limestone with black laminae & nd & 3.72 & 427 & 0.33 & 13.26 & 357 & 45 \\
\hline $111 \mathrm{R}-1,118-119$ & 1040.48 & Limestone with black laminae & 82 & 1.13 & 429 & 0.10 & 4.26 & 375 & 77 \\
\hline $111 \mathrm{R}-2,8-9$ & 1040.67 & Limestone with black laminae & 67 & 1.92 & 425 & 0.14 & 4.26 & 222 & 72 \\
\hline $112 \mathrm{R}-1,48-50$ & 1049.38 & Limestone with black laminae & 83 & 2.05 & 420 & 0.63 & 13.94 & 682 & 43 \\
\hline $113 R-C C, 44-45$ & 1058.94 & Limestone with black laminae & 53 & 4.99 & 422 & 0.92 & 24.74 & 496 & 27 \\
\hline $114 \mathrm{R}-1,27-28$ & 1068.47 & Limestone with black laminae & 35 & 4.05 & 423 & 0.60 & 11.28 & 279 & 31 \\
\hline $116 \mathrm{R}-1,33-35$ & 1087.83 & Limestone with black laminae & 67 & 0.94 & 433 & 0.05 & 2.80 & 298 & 82 \\
\hline $117 \mathrm{R}-1,9-11$ & 1097.19 & Black argillaceous laminated limestone & 34 & 0.48 & $370^{*}$ & & 0.06 & $13^{*}$ & $145^{*}$ \\
\hline $117 \mathrm{R}-2,56-57$ & 1099.16 & Limestone with black laminae & 7 & 0.41 & 460 & 0.00 & 0.34 & 83 & 77 \\
\hline 118R-2, 97-98 & 1109.27 & Limestone with black laminae & nd & 8.74 & 429 & 0.62 & 23.03 & 263 & 30 \\
\hline 119R-1, 89-91 & 1117.39 & Gray limestone & 89 & 0.15 & & & & & \\
\hline $120 \mathrm{R}-1,8-10$ & 1126.18 & Limestone with black laminae & 0 & 0.27 & 445 & 0.06 & 0.58 & 213 & 156 \\
\hline $124 \mathrm{R}-1,114-116$ & 1165.94 & Gray limestone with clay layers & 71 & 0.63 & 419 & 0.00 & 0.39 & 62 & 218 \\
\hline $125 \mathrm{R}-3,47-49$ & 1177.80 & Gray limestone & 74 & 0.49 & 424 & & 0.31 & 63 & 224 \\
\hline $128 \mathrm{R}-1,62-63$ & 1203.82 & Limestone with black laminae & 71 & 0.58 & 421 & 0.02 & 0.37 & 62 & 135 \\
\hline $128 \mathrm{R}-2,31-32$ & 1204.65 & Limestone with black laminae & 51 & 8.87 & 408 & 2.70 & 49.87 & 562 & 28 \\
\hline $129 \mathrm{R}-1,14-15$ & 1213.04 & Limestone with black laminae & 60 & 12.66 & 410 & 4.94 & 74.49 & 588 & 35 \\
\hline $129 \mathrm{R}-1,44-45$ & 1213.34 & Dark gray mudstone & 33 & 0.56 & $372 *$ & & 0.04 & $7^{*}$ & $228 *$ \\
\hline $130 \mathrm{R}-1,85-86$ & 1223.45 & Limestone with black laminae & 68 & 9.35 & 402 & 3.57 & 48.74 & 521 & 32 \\
\hline $132 \mathrm{R}-1,15-17$ & 1242.05 & Limestone with black laminae & 82 & 0.62 & 417 & 0.02 & 1.92 & 312 & 95 \\
\hline $144 \mathrm{R}-1,53-54$ & 1358.03 & Black argillaceous laminated limestone & 50 & 2.70 & 429 & 0.11 & 4.72 & 175 & 58 \\
\hline $144 \mathrm{R}-1,58-59$ & 1358.08 & Black argillaceous laminated limestone & 45 & 0.87 & 412 & 0.03 & 0.29 & 34 & 95 \\
\hline $144 \mathrm{R}-1,64-65$ & 1358.14 & Gray limestone & 90 & 0.12 & & & & & \\
\hline $145 \mathrm{R}-1,147-149$ & 1368.27 & Limestone with black laminae & 27 & 3.25 & 421 & 0.14 & 5.62 & 173 & 41 \\
\hline $145 \mathrm{R}-2,24-26$ & 1368.54 & Dark gray claystone & 0 & 0.17 & & & & & \\
\hline $146 \mathrm{R}-1,107-108$ & 1377.47 & Limestone with black clayey laminae & 60 & 1.15 & 428 & 0.05 & 2.07 & 180 & 87 \\
\hline $146 \mathrm{R}-2,22-24$ & 1378.12 & Black argillaceous laminated limestone & 71 & 1.12 & 426 & 0.05 & 2.17 & 194 & 88 \\
\hline $147 \mathrm{R}-1,45-46$ & 1386.55 & Black greenish claystone & 0 & 0.16 & & & & & \\
\hline $147 \mathrm{R}-1,89-90$ & 1386.99 & Limestone with black clayey laminae & 44 & 0.24 & & & & & \\
\hline $147 \mathrm{R}-1,91-92$ & 1387.01 & Black sandy claystone & 22 & 0.56 & 386 & 0.00 & 0.16 & 28 & 94 \\
\hline $148 \mathrm{R}-1,86-87$ & 1396.56 & Black sandy claystone & 26 & 0.29 & $364^{*}$ & & 0.01 & $5^{*}$ & $207^{*}$ \\
\hline 148R-2, 104-105 & 1398.16 & Black sandy claystone & 68 & 0.57 & $373^{*}$ & & 0.04 & $6 *$ & $155^{*}$ \\
\hline $148 \mathrm{R}-3,0-3$ & 1398.27 & Black argillaceous laminated limestone & 41 & 0.51 & 412 & 0.00 & 0.22 & 44 & 147 \\
\hline $148 \mathrm{R}-3,60-61$ & 1398.87 & Green claystone & 42 & 0.45 & 435 & 0.03 & 0.07 & 16 & 134 \\
\hline $148 \mathrm{R}-3,81-82$ & 1399.08 & Limestone with black laminae & 28 & 0.86 & 427 & 0.03 & 1.83 & 212 & 72 \\
\hline
\end{tabular}

Notes: $\mathrm{TOC}=$ total organic carbon $(\mathrm{wt} \%), T_{\max }=$ maximum temperature, $\mathrm{S}_{1}=$ free hydrocarbons, and $\mathrm{S}_{2}=$ pyrolyzable hydrocarbons (in mg/g of rock), $\mathrm{HI}=$ hydrogen index (in mg $\mathrm{HC} / \mathrm{g} \mathrm{TOC}$ ), and $\mathrm{OI}=$ oxygen index (in $\mathrm{mg} \mathrm{CO}_{2} / \mathrm{g}$ TOC). $\mathrm{nd}=$ not determined and * = doubtful data resulting from a small $\mathrm{S}_{2}$ peak.

shoulder on the 002 reflection of kaolinite at $3.57 \AA$ (e.g., Sample 143-865A-89R-3, 65-70 cm, Fig. 9) in the absence of chlorite (no peak at about 14 or $4.7 \AA$ ). This reflection is attributed to the iron-rich 1:1 layer silicate called berthierine.

A strong mineralogical change occurs within Subunit IVC between Samples 143-865A-89R-2, 110-115 cm (827.27 mbsf), and $-89 \mathrm{R}-2,2-4 \mathrm{~cm}$ ( $826.19 \mathrm{mbsf})$. The lowermost part of the subunit (from 827.27 mbsf to bottom) shows dominant I/S, minor kaolinite, and berthierine and the common occurrence of goethite and gibbsite. By contrast, the clay fraction from the upper part of this subunit is characterized by dominant kaolinite and berthierine, minor I/S, and by the occurrence of illite (Fig. 7). Goethite and gibbsite are not identified in this part of the subunit.

The clay fraction of the wackestones and packstones from Subunit IVB consists of dominant random I/S associated with illite and kaolinite. According to the saddle index, which is between 0.73 and 0.95 , the percentages of smectite layers in the I/S mixed-layers range between $40 \%$ and $65 \%$.

\section{Hole 866A}

The carbonate content of Units IV and V is high (up to 64\%), except for a green claystone level at $658.52 \mathrm{mbsf}$, which is devoid of carbonate (Table 1). Units VI and VII present contrasting carbonate contents according to their lithologies (Fig. 10). As expected, claystones, sandy claystones, and limestones having dark clayey laminae are carbonate-poor $(0 \%-50 \%)$, whereas the carbonate content reaches $70 \%$ to $90 \%$ in gray wackestones and packstones.
In contrast to Hole $865 \mathrm{~A}$, clay mineralogical changes do not coincide with unit or subunit boundaries (Fig. 11). The clay assemblages consist of a mixture of dominant illite and I/S mixed-layer that occurs together with minor chlorite $(0 \%-25 \%)$ and generally less than $10 \%$ of kaolinite, except in Samples 143-866A-55R-CC, 1-2 cm, and $-120 \mathrm{R}-1,8-9 \mathrm{~cm}$, which are enriched in kaolinite. Illite and I/S show great variations in quantity, whereas goethite and celestite occur in few samples.

The most striking feature is the occurrence, at the base of Unit IV and in the two studied samples of Unit V, of monomineral clay fractions composed of illitic material including illite and I/S (Fig. 12). Illite is identified in Sample 143-866A-71R-2, 74-75 cm, according to the position of the 002 and 003 peaks at $17.7^{\circ}$ and $26.7^{\circ}$, respectively, and to the Ir index, which is very close to 1 . Small amounts of ISII mixed-layers are probably associated with illite (Srodon and Eberl, 1984). Regular I/S, with a proportion of illite layers between $40 \%$ and $60 \%$, was identified in Sample 143-866A-73R-1, 42-43 cm. More illitic random $\mathrm{V} / \mathrm{S}$ (60\%-70\% of illite layers) occur in Sample $143-866$ A-74R-2, 74-75 cm. Chemical analyses of the clay fraction of these three samples are reported in Table 2 . They indicate mainly an iron-rich composition and an increase of potassium from random I/S through ordered I/S then to illite. TEM observations indicate that the illitic particles are of very small sizes $(<0.5 \mu \mathrm{m}$, Fig. 13).

In Units VI and VII, clay assemblages are dominated by illite, but in some samples, random $\mathrm{I} / \mathrm{S}$ are abundant (more than $90 \%$, e.g., Samples 143-866A-106R-1, 75-76 cm, and -117R-2, 56-57 cm, Fig. 11). According to the saddle index, the percentages of smectite layers range 
Table 2. Chemical analyses of the clay fraction of selected samples from Hole 866A.

\begin{tabular}{lccccccccc}
\hline $\begin{array}{c}\text { Core, section, } \\
\text { interval }(\mathrm{cm})\end{array}$ & $\begin{array}{c}\text { Depth } \\
(\mathrm{mbsf})\end{array}$ & $\begin{array}{l}\mathrm{SiO}_{2} \\
(\%)\end{array}$ & $\begin{array}{c}\mathrm{Al}_{2} \mathrm{O}_{3} \\
(\%)\end{array}$ & $\begin{array}{c}\mathrm{Fe}_{2} \mathrm{O}_{3} \\
(\%)\end{array}$ & $\begin{array}{c}\mathrm{MgO} \\
(\%)\end{array}$ & $\begin{array}{c}\mathrm{TiO}_{2} \\
(\%)\end{array}$ & $\begin{array}{c}\mathrm{K}_{2} \mathrm{O} \\
(\%)\end{array}$ & $\begin{array}{c}\mathrm{Na}_{2} \mathrm{O} \\
(\%)\end{array}$ & $\begin{array}{c}\mathrm{CaO} \\
(\%)\end{array}$ \\
\hline 143-866A- & & & & & & & & & \\
$71 \mathrm{R}-2,74-75$ & 658.52 & 55.00 & 20.71 & 10.40 & 5.17 & 1.33 & 7.19 & 0.21 & 0.00 \\
$73 \mathrm{R}-1,42-43$ & 676.22 & 54.16 & 27.87 & 6.17 & 2.67 & 3.29 & 5.43 & 0.18 & 0.23 \\
$74 \mathrm{R}-2,74-75$ & 687.52 & 58.03 & 22.10 & 9.34 & 4.62 & 1.52 & 3.88 & 0.08 & 0.41 \\
106R-1,75-77 & 991.65 & 58.18 & 26.61 & 5.17 & 4.44 & 2.75 & 2.50 & 0.09 & 0.28 \\
117R-2,56-57 & 1099.16 & 61.10 & 22.82 & 5.67 & 5.84 & 0.92 & 3.16 & 0.34 & 0.15 \\
146R-2,22-24 & 1368.54 & 56.64 & 23.14 & 7.63 & 4.48 & 3.00 & 4.83 & 0.09 & 0.17 \\
\hline
\end{tabular}

Figure 6. Calcium carbonate percentages, organic carbon content, and variations in hydrogen and oxygen indices of sediments from Unit IV, Hole 865A.

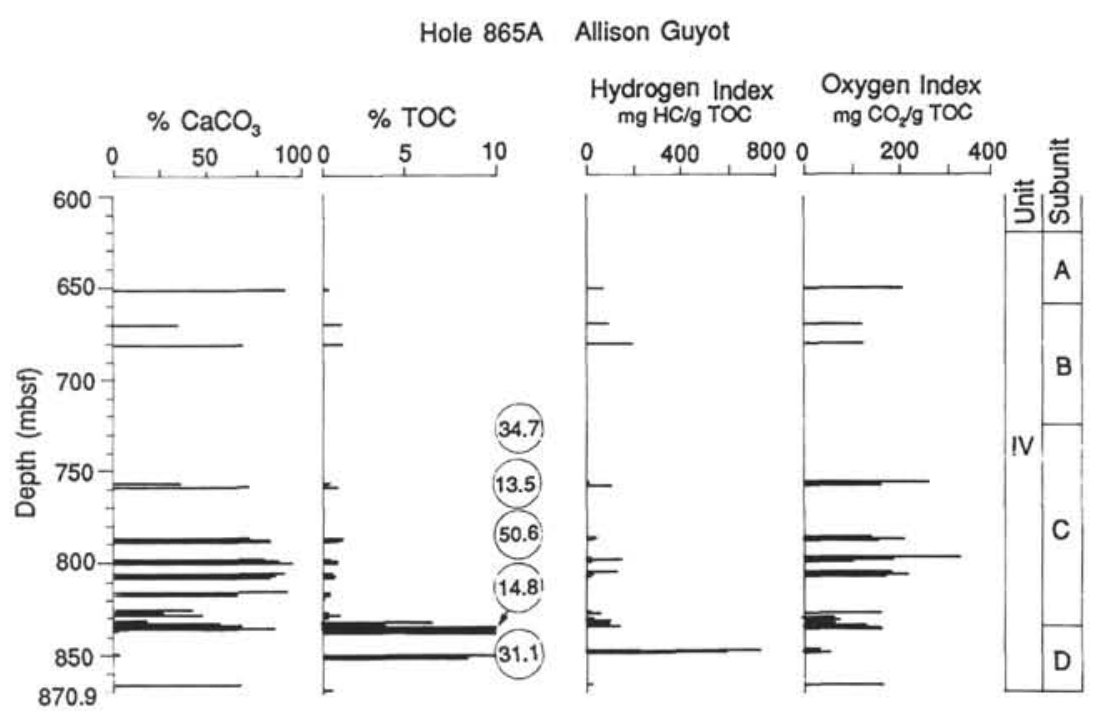

from $30 \%$ to $60 \%$. Chemical analyses of the clay fraction of these samples are reported in Table 2. They indicate a dioctahedral character of the smectite layers belonging to the montmorillonite-beidellite group.

\section{Organic Carbon}

The distribution of total organic carbon contents observed in the holes is classified as follows: (1) very rich, more than $5 \%$; (2) rich, $1 \%$ to $5 \%$; (3) mean, $0.5 \%$ to $1 \%$; (4) low, $0.25 \%$ to $0.5 \%$; and (5) very low, less than $0.25 \%$.

\section{Hole 865 A}

Low to very low organic carbon content (less than $0.5 \%$ ) characterizes the gray green pyritic claystones and most of the bioturbated clayey wackestones and packstones (Table 1). Some exceptions occur in Samples 143-865A-73R-1, 23-24 cm; -74R-1, 110-112 cm; -85R$2,3-4 \mathrm{~cm}$, and $-90 \mathrm{R}-2,33-34 \mathrm{~cm}$, which present a slightly higher organic-carbon content at about $1 \%$ (Fig. 6).

Most samples from Sections 143-865A-89R-3 to -92R-2 are rich to very rich in organic carbon. The richest samples $(6 \%-50 \%)$ correspond everywhere to black and brown claystones, whereas some coaly claystones and packstones show only mean organic content (about $1 \%$ or less).

\section{Hole 866A}

TOC percentages present high-amplitude variations that range from $0.1 \%$ to $34.47 \%$ (Table 1 ). As a general rule, the higher TOC contents $(>3 \%)$ are recorded in laminated limestones of Units IV and VII (Fig. 10), whereas algal or cyanobacterial mats and claystones with plant debris likewise present high TOC values in Unit VI. Unit $\mathrm{V}$, investigated by only two samples, shows very low TOC values $(<0.2 \%)$, as expected in oolitic grainstone facies. Gray limestones, sandy claystones, and green clay layers from Units IV to VII are low in TOC content (generally less than $0.5 \%$ ). Not all dark claystone intervals have the highest TOC values. Some of them, corresponding to Samples 143-866A-88R-1, 140-142 cm; -145R-2, 24-26 cm; $-147 \mathrm{R}-1,45-46 \mathrm{~cm}$; and $-148 \mathrm{R}-3,60-61 \mathrm{~cm}$, contain only $0.16 \%$ to $0.36 \%$ organic carbon, although these intervals were suspected and described as organic-rich on board the JOIDES Resolution (Shipboard Scientific Party, 1993).

Several pairs of samples only 2 or $3 \mathrm{~cm}$ apart present great differences in TOC content. For instance, samples at 512.02 and 512.05 mbsf contain $4.08 \%$ and $1.38 \%$ TOC, respectively, yet have almost the same carbonate content $\left(71 \%\right.$ and $\left.74 \% \mathrm{CaCO}_{3}\right)$. Samples at 571.47 and 571.5 mbsf demonstrate the same tendency, with $1.24 \%$ and $0.28 \%$ TOC for an equal carbonate content. The most extreme difference reaches $31 \%$ in samples at 795.22 and 795.25 mbsf, which present the same "algal mat" lithofacies. Two black argillaceous laminated limestone samples from 1358.03 and 1358.08 mbsf contain $2.7 \%$ and $0.87 \%$ TOC, respectively. All these examples indicate a lower TOC content in the lower part of the studied interval than in its upper part. Only interval 143-866A-89R-1, 92-100 cm, presents the reverse tendency with the most pronounced TOC-difference. Organic contents vary between $0.49 \%$ and $14.38 \%$, whereas carbonate contents fluctuate from $15 \%$ to $87 \%$ (Fig. 14).

\section{Nature of Organic Matter}

Three types of organic matter can be distinguished in rocks and sediments from pyrolysis studies (Espitalié et al., 1985a, 1985b, 1986). Types I and II are related to lacustrine or marine-reducing environments and are derived mainly from algae or bacteria, whereas type III is derived from terrestrial plants, transported to marine or nonmarine environments with a moderate level of degradation. Intermediate kerogens are common, particularly between types II and III. 


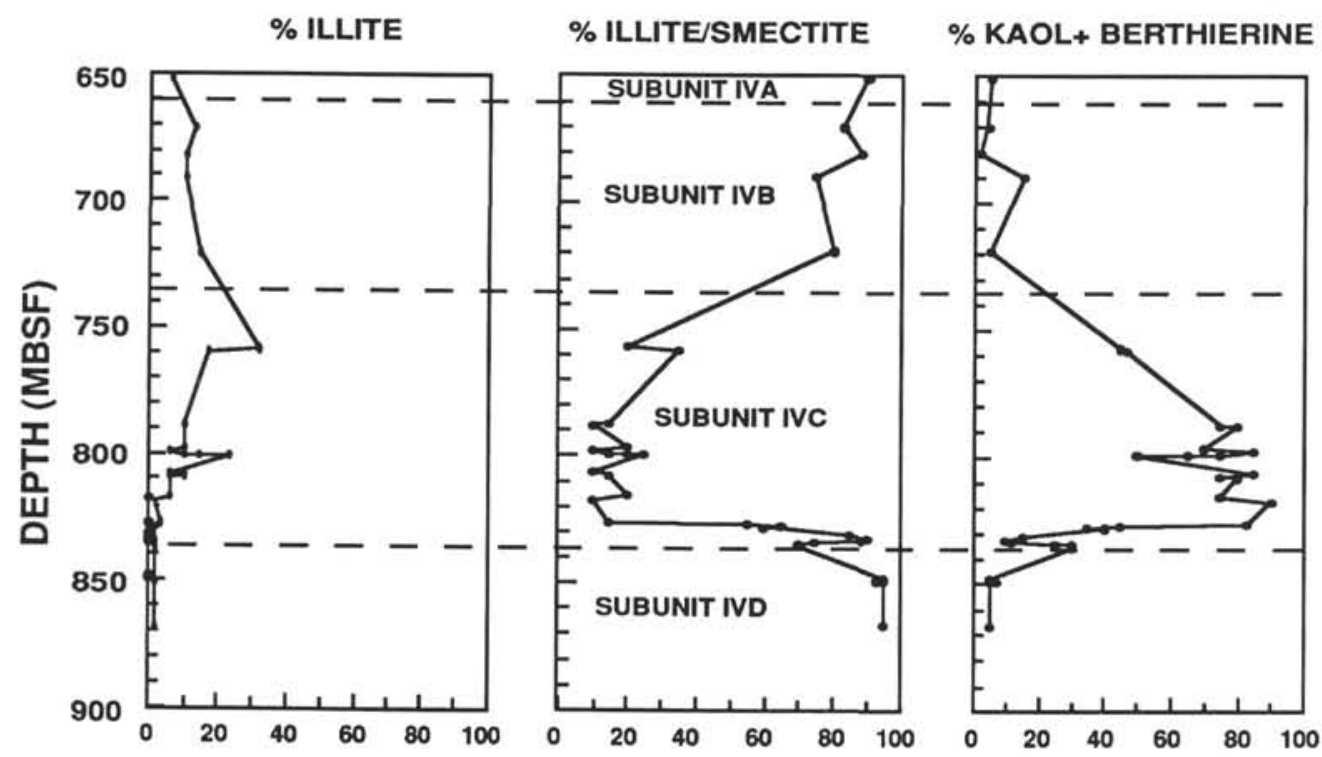

Figure 7. Clay mineralogy of sediments from Unit IV of Hole 865A.

They result from a mixture of marine and terrestrial organic matter or from selective biodegradation of organic matter. A fourth type of organic matter, sometimes called type IV, corresponds to residual organic matter that may be either recycled from older sediments by erosion or deeply altered by weathering (Tissot, 1984).

\section{Hole $865 \mathrm{~A}$}

The origin of organic matter is mainly terrestrial (type III) according to the relatively low $\mathrm{HI}$ values (around 150) and medium OI values (between 50 and 150) shown in Figure 15. Black or coaly claystones demonstrate mainly a type III distribution, and only two samples contain types I or II organic matter. These samples from the bottom of Subunit IVD reach $730 \mathrm{mg} \mathrm{HC} / \mathrm{g}$ TOC.

It is also clear from the HI-OI diagram (Fig. 15) that low HI related to high OI typifies the relatively organic-poor wackestones and packstones. These samples are regarded here as containing an altered organic matter (type IV).

\section{Hole 866 A}

The organic matter is widely distributed between types I and IV, according to the broad distribution of $\mathrm{HI}$ values, which range from 5 to $784 \mathrm{mg} \mathrm{HC} / \mathrm{g}$ TOC (Fig. 15). Laminated limestones and algal mats clearly show the highest HIs and are related to types I or II organic matter. Nevertheless, such facies may likewise coincide with indices of less than 50. These low values, correlated with low organic-carbon contents and relatively high OIs, support a hypothesis for important amounts of alteration.

Black claystones and clays with plant debris show low to medium HIs (50 to 200), suggesting a type III organic matter. Other lithologies generally have low $\mathrm{HI}$ and high OI values, pointing to a type IV organic matter.

Type II organic matter is mainly distributed in Units IV and VI, whereas type IV typifies Unit V and is abundant in Unit VII (Fig. 16). Type III organic matter is mostly limited to Subunit VIA within the terrestrial-plant-rich interval of Core 143-866A-89R.

\section{Maturation}

Maturation level of the organic matter is estimated by both the $T_{\max }$ parameter provided by Rock-Eval and the vitrinite reflectance measurements on kerogen concentrates. The first requirement for using

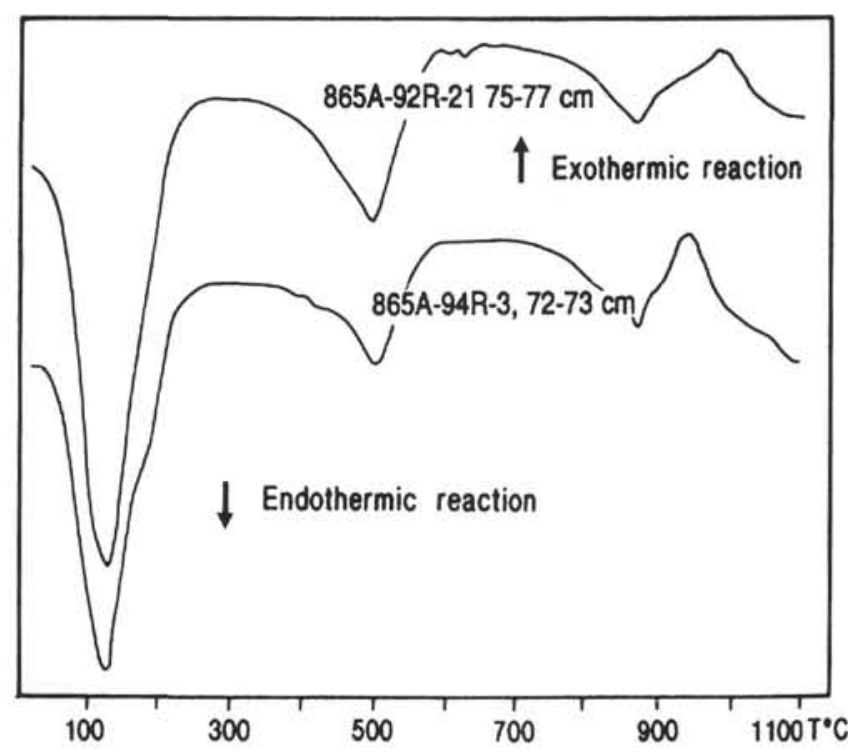

Figure 8. Differential thermal analyses of the illite-smectite mixed-layers from sediments of Subunit IVD.

$T_{\max }$ data is an organic-carbon content higher than $0.25 \%$ and an $\mathrm{S}_{2}$ peak greater than $0.1 \mathrm{mg} \mathrm{HC} / \mathrm{g}$ rock (Espitalié et al., 1985a, 1985b, 1986). Thus, $T_{\max }$ for the shallowly buried material that has a low organic carbon content is here disregarded. $T_{\max }$ can be plotted vs. HIs (Fig. 17) to estimate the maturation of samples. Evolution paths for the three reference types of organic matter (types I, II, and III) and isoreflectance curves $(0.5 \%, 1 \%$, and $1.5 \%)$ of vitrinite are outlined following Espitalié et al. (1985a, 1985b, 1986).

\section{Hole $865 \mathrm{~A}$}

The range of $T_{\max }$ values observed in Hole $865 \mathrm{~A}$ is $409^{\circ}$ to $433^{\circ} \mathrm{C}$ for the interpretable $T_{\max }$ values (Table 1). There is no clear evolution of $T_{\max }$ with depth, and this parameter presents a large variation in amplitude for the organic carbon-rich interval that extends between 800 and 850 mbsf. 


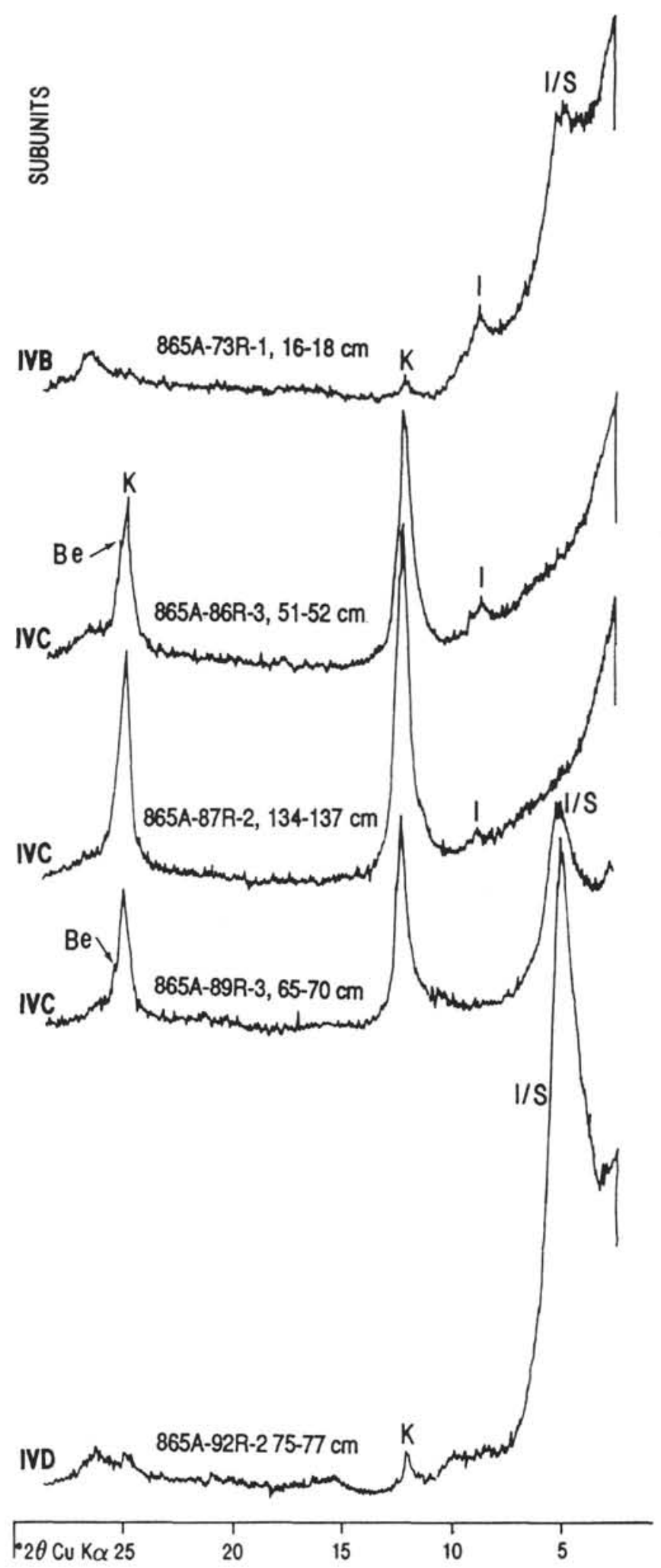

Figure 9. Typical $\mathrm{X}$-ray diffraction patterns (glycolated) of the clay fraction from samples of Unit IV (Hole 865A). I/S = illite-smectite mixed-layers, I = illite, $\mathrm{K}=$ kaolinite, $\mathrm{Be}=$ berthierine .
Two organic carbon-rich samples corresponding to coaly claystone facies reveal abnormally low $T_{\max }$ values (around $390^{\circ} \mathrm{C}$ ), which may correspond either to altered organic matter, or to determination of unreliable $T_{\max }$ values. We know that this Rock-Eval parameter may be erratic in coal and coaly organic matter (Peters, 1986).

Basaltic intrusions that occur in Subunit IVD do not disturb the $T_{\max }$ parameter, as the lowermost studied sample (143-865A-94R-3, $72-73 \mathrm{~cm}$ ), which is sandwiched between two sills, has only a $T_{\max }$ value of $424^{\circ} \mathrm{C}$. A comparable situation of basaltic intrusion and low $T_{\max }$ value in the vicinity was noted in DSDP Site 368 (Deroo et al., 1977 ) as well as in outcrop (Correia and Maury, 1975; Baudin and Téhérani, 1991).

Measured vitrinite reflectance data range from $0.33 \%$ to $0.47 \% \mathrm{R}_{\mathrm{r}}$ (Table 3). Accordingly, all samples are immature, as already suggested by the low $T_{\max }$ values, the abundance of smectitic layers in I/S, and the strong positive alteration of the fluorescence intensity of alginite (see below). Nevertheless, vitrinite reflectance seems relatively high, considering the shallow depth of burial. Perhaps this and the large scatter of the reflectance values are an effect of the basaltic sills or the result of oxidation of organic matter during sedimentation.

\section{Hole 866 A}

The range of interpretable $T_{\max }$ values in Hole 866A has a large amplitude, from $386^{\circ}$ to $434^{\circ} \mathrm{C}$ (Table 1). Three samples present high $T_{\max }$ values $\left(452^{\circ}\right.$ to $\left.551^{\circ} \mathrm{C}\right)$, which are abnormal considering the shallow depth of burial and the probable absence of a thermal anomaly. It is obvious from the Rock-Eval pyrograms that these samples have a complicated (bimodal or trimodal) $S_{2}$ peak. This may represent a mixture of immature and very mature (charred?) organic matter, which disturbs the $T_{\max }$ determination. Cracking of unusual carbonates (siderite, dawsonite, nacolite, or others) also may explain abnormal $T_{\max }$ measurements. Except for this anomaly, all the other studied samples are immature. Our conclusion of immaturity is also supported by vitrinite reflectance data that range from $0.28 \% \mathrm{R}_{\mathrm{r}}$ at a depth of $512 \mathrm{~m}$ to $0.42 \% \mathrm{R}_{\mathrm{r}}$ at a depth of $1110 \mathrm{~m}$ (Table 3 ).

In the HI vs. $T_{\max }$ diagram (Fig. 17), most data plot in the area below the $T_{\max }$ threshold of $435^{\circ} \mathrm{C}$ and the $0.5 \%$ isoreflectance curve, further evidence of an immature stage of all samples from Holes 865A and $866 \mathrm{~A}$.

\section{Petroleum Potential}

Total hydrocarbons $\left(\mathrm{S}_{1}+\mathrm{S}_{2}\right)$ expelled during Rock-Eval pyrolysis represent the petroleum potential, expressed in kilograms of $\mathrm{HC}$ per ton of rock.

\section{Hole 865 A}

Very low to low petroleum potentials, less than $1 \mathrm{~kg} / \mathrm{t}$, characterize the carbonate-rich wackestones and packstones, whereas medium to good potentials $(1-20 \mathrm{~kg} / \mathrm{t}$ ) can be observed in most carbonaceous facies. The sample containing up to $50 \%$ TOC would be able to generate only $23 \mathrm{~kg} / \mathrm{t}$, suggesting a low hydrogen content of this organic matter.

Two samples from the bottom of Subunit IVD that correspond to black claystones and gray wackestones, respectively, however, do have good potential for petroleum. Sample 143-865A-91R-5, 130-132 $\mathrm{cm}$, may generate $50 \mathrm{~kg} / \mathrm{t}$, and Sample 143-865A-92R-2, 58-60 cm, may generate up to $180 \mathrm{~kg} / \mathrm{t}$, implying a high hydrogen content of organic matter.

\section{Hole $866 \mathrm{~A}$}

Very low to low petroleum potentials $(<1 \mathrm{~kg} / \mathrm{t})$ characterize the gray limestones, black sandy claystones, and dark green claystones. Good to very good potentials $(5-79.5 \mathrm{~kg} / \mathrm{t})$ were observed in most laminated limestones and algal or cyanobacterial mats, whereas lime- 
Table 3. Maceral percentages and mean vitrinite reflectance values of samples from Holes 865A and 866A.

\begin{tabular}{|c|c|c|c|c|c|c|c|c|c|c|c|}
\hline \multirow{2}{*}{$\begin{array}{l}\text { Core, section, } \\
\text { interval }(\mathrm{cm})\end{array}$} & \multirow{2}{*}{$\begin{array}{l}\text { Depth } \\
\text { (mbsf) }\end{array}$} & \multirow{2}{*}{$\begin{array}{c}\text { Vitrinite } \\
(\%)\end{array}$} & \multirow{2}{*}{$\begin{array}{c}\text { Inertinite } \\
(\%)\end{array}$} & \multirow{2}{*}{$\begin{array}{l}\text { Higher-plant } \\
\text { liptinite }(\%)\end{array}$} & \multirow{2}{*}{$\begin{array}{c}\text { Telaginite } \\
(\%)\end{array}$} & \multirow{2}{*}{$\begin{array}{c}\text { Lamalginite } \\
\text { (\%) }\end{array}$} & \multirow{2}{*}{$\begin{array}{c}\text { Bituminite } \\
(\%)\end{array}$} & \multirow{2}{*}{$\begin{array}{c}\text { Liptodetrinite } \\
(\%)\end{array}$} & \multirow{2}{*}{$\begin{array}{l}\text { Vitrinite } \\
\operatorname{Rr}(\%)\end{array}$} & \multicolumn{2}{|c|}{ Reflectance } \\
\hline & & & & & & & & & & $\mathrm{n}$ & s \\
\hline \multicolumn{12}{|l|}{$143-865 \mathrm{~A}-$} \\
\hline $74 \mathrm{R}-1,110-112$ & 680.80 & n.d. & n.d. & n.d. & n.d. & n.d. & n.d. & n.d. & 0.40 & 40 & 0.05 \\
\hline $89 \mathrm{R}-6,11-15^{\mathrm{a}}$ & 831.48 & 97 & 1 & 1 & 0 & 0 & 0 & 0 & 0.40 & 49 & 0.05 \\
\hline $90 R-2,33-34^{a}$ & 833.27 & n.d. & n.d. & n.d. & n.d. & n.d. & n.d. & n.d. & 0.33 & 30 & 0.07 \\
\hline $90 \mathrm{R}-3,37-38$ & 834.61 & 97 & Traces & 3 & 0 & 0 & 0 & 0 & 0.42 & 50 & 0.03 \\
\hline $90 \mathrm{R}-3,95-96$ & 835.19 & 97 & 0 & 1 & 0 & 0 & 2 & Traces & 0.41 & 50 & 0.05 \\
\hline $90 \mathrm{R}-3,112-113$ & 835.36 & 80 & 2 & 1 & 1 & 1 & 13 & 2 & 0.47 & 45 & 0.05 \\
\hline $91 \mathrm{R}-5,130-132$ & 848.06 & 5 & Traces & 1 & 86 & 3 & Traces & 5 & 0.35 & 21 & 0.03 \\
\hline $92 \mathrm{R}-2,44-47$ & 849.07 & 61 & 4 & $i$ & 24 & 3 & 7 & Traces & 0.41 & 50 & 0.05 \\
\hline $92 \mathrm{R}-2,58-60$ & 849.21 & 26 & Traces & Traces & 55 & 2 & 8 & 9 & 0.41 & 50 & 0.05 \\
\hline \multicolumn{12}{|l|}{$143-866 \mathrm{~A}-$} \\
\hline $56 \mathrm{R}-1,42-43$ & 512.02 & 2 & Traces & 0 & 0 & 63 & 34 & 1 & $0.28 ?$ & 5 & 0.02 \\
\hline $63 \mathrm{R}-2,109-111$ & 581.89 & 5 & 1 & 0 & 15 & 38 & 41 & Traces & 0.37 & 30 & 0.06 \\
\hline $85 R-3,50-52$ & 795.25 & Traces & 0 & 0 & 0 & 67 & 31 & 2 & $0.38 ?$ & 7 & 0.07 \\
\hline $86 \mathrm{R}-1,143-145$ & 802.93 & 2 & 0 & 0 & 0 & 23 & 75 & Traces & n.d. & & \\
\hline $86 \mathrm{R}-2,111-113$ & 804.11 & 1 & 1 & 0 & 0 & 51 & 47 & Traces & n.d. & & \\
\hline $89 \mathrm{R}-1,98-99$ & 831.58 & 35 & 2 & 4 & 0 & 24 & 35 & Traces & 0.40 & 37 & 0.04 \\
\hline $110 \mathrm{R}-1,89-90$ & 1030.49 & 10 & 1 & Traces & 0 & 34 & 53 & 2 & 0.38 & 39 & 0.03 \\
\hline $111 \mathrm{R}-1,86-87$ & 1040.16 & 0 & Traces & 0 & 0 & 17 & 80 & 3 & n.d. & & \\
\hline $118 \mathrm{R}-2,97-98$ & 1109.27 & 26 & 2 & 6 & 1 & 13 & 50 & 2 & 0.42 & 50 & 0.05 \\
\hline $144 \mathrm{R}-1,53-54$ & 1358.03 & n.d. & n.d. & n.d. & n.d. & n.d. & n.d. & n.d. & n.d. & & \\
\hline
\end{tabular}

Note: $\mathrm{n} . \mathrm{d} . \mathbf{=}$ not determined.

a Whole-round sample.

Hole 866A Resolution Guyot
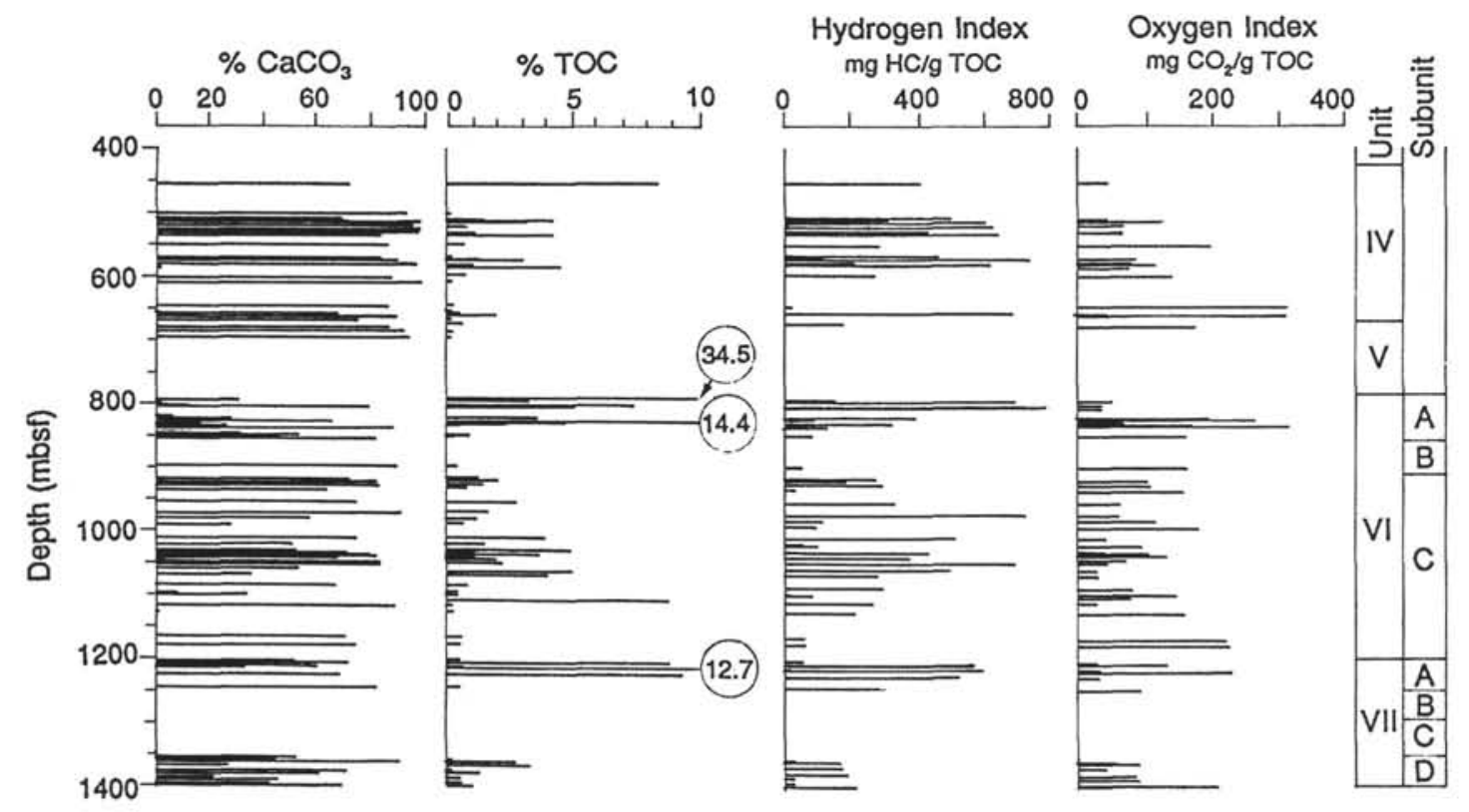

Figure 10. Calcium carbonate percentages, organic carbon content, and variations in hydrogen and oxygen indices of sediments from Units IV to VII, Hole 866A.

stones and claystones with plant debris display medium to good potentials $(1-18 \mathrm{~kg} / \mathrm{t})$.

\section{Kerogen Study}

\section{Hole 865 A}

Eight samples were selected for the preparation of kerogen concentrates. Most samples are from the lowermost part of Unit IV; only one is from the top of Unit IV. The data derived from kerogen microscopy are summarized in Table 3 .

Vitrinite is the prevailing maceral group in most samples from Subunit IVD. Sample 143-865A-90R-3, 37-38 cm, contains nearly exclusively completely gelified telinite. Suberinite is the main maceral of the liptinite group in this sample. Resinite occurs rarely. Other vitriniterich samples are characterized by higher ratios of vitrodetrinite over telinite. In these samples, alginite, bituminite, and liptodetrinite occur only in traces. Microcracks in a few vitrinite particles from Sample 143-865A-90R-3, 112-113 cm, may indicate oxidation. Because pyrite is not weathered, oxidation must have occurred before burial.

The organic material from samples between 848.00 and 849.25 mbsf is characterized by significant amounts of telaginite, with wellpreserved cell structures derived from colonial algae. The telalginite exhibits a yellow to orange fluorescence. Its intensity of fluorescence increases significantly during $30 \mathrm{~min}$ of irradiation (= positive alteration). The greatest amount of telaginite $(86 \%)$ occurs in Sample 143-865A-91R-5, 130-132 cm, which contains only minor vitrinite 

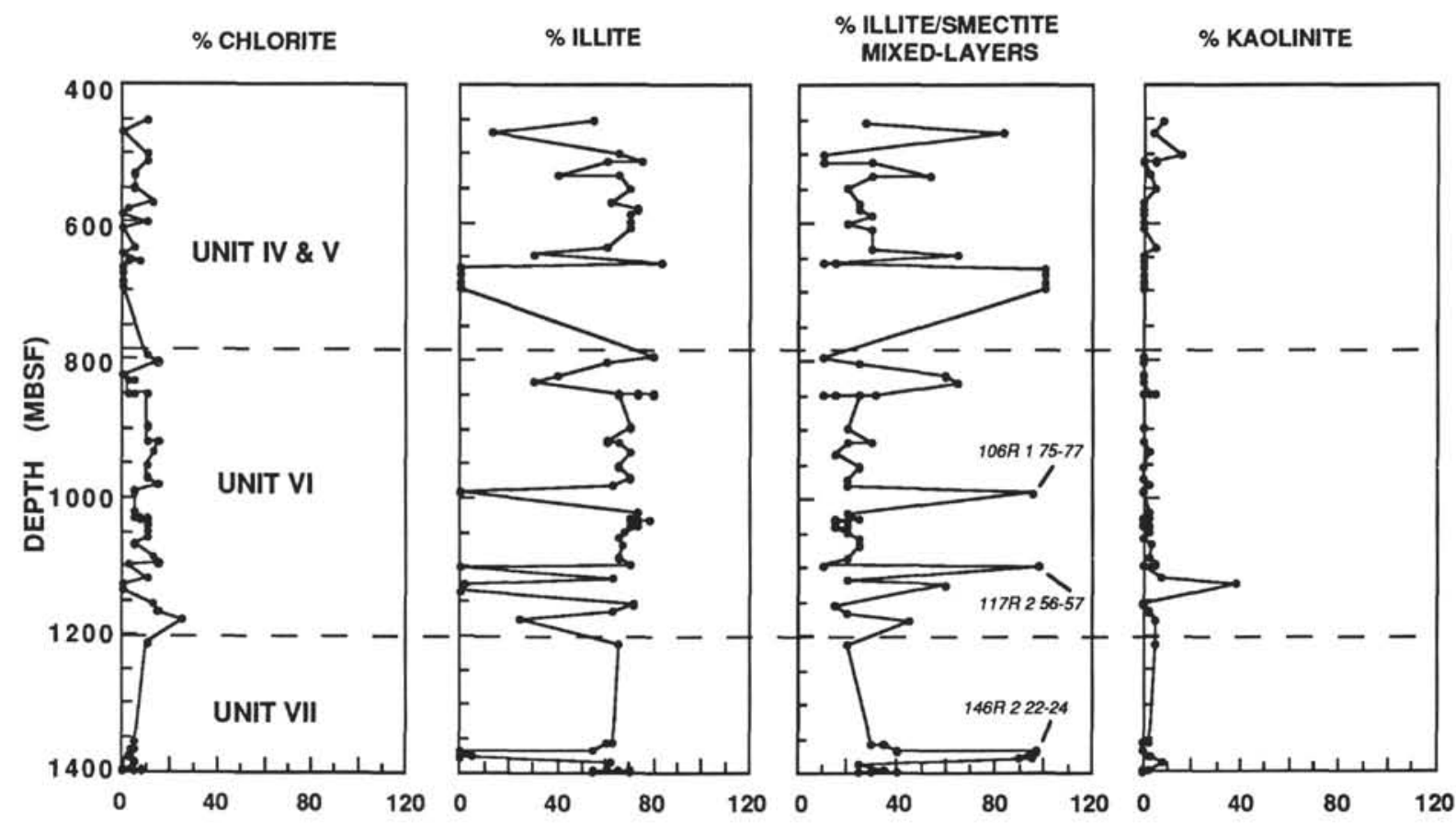

Figure 11. Clay mineralogy of sediments from Units IV to VII of Hole 866A.

(Pl. 2, Fig. 1). Sample 143-865A-92R-2, 44-47 cm, contains $24 \%$ telaginite and $61 \%$ vitrinite, and Sample 143-865A-92R-2, 58-60 $\mathrm{cm}$, contains $55 \%$ telaginite and $26 \%$ vitrinite (Pl. 2, Fig. 2). Other macerals (inertinite, bituminite, lamalginite, higher plant liptinites, liptodetrinite) occur only in small amounts $(<10 \%)$. Oval-shaped bitumen droplets can be observed in one sample.

Organic petrographical methods do not allow us to decide whether the telaginite is derived from Gloeocapsomorpha- or from Botryococcus-related algae. Palynological investigations in transmitted light, however, suggest a strong affinity to Gloeocapsomorpha (Riegel, pers. comm., 1993). Gloeocapsomorpha is the precursor of telaginite in the Estonian oil shale kukersite and is indicative of a normal marine environment, whereas Botryococcus is essentially a freshwater genus, but is tolerant to brackish-water conditions (Foster et al., 1989).

Aclear correlation exists between the liptinite content of these samples and their HI (Fig. 18). According to this correlation, an HI-value of $844 \mathrm{mg} \mathrm{HC} / \mathrm{g}$ TOC is calculated for pure liptinites, whereas the calculated HI-value for a liptinite-free kerogen is $62 \mathrm{mg} \mathrm{HC} / \mathrm{g}$ TOC.

The mineral-matrix effect results in a diminution of pyrolysis yield and, hence, in an underestimation of $\mathrm{HI}$, as well as in an overestimation of $T_{\max }$, when samples contain clays and less than $4 \%$ organic carbon (Espitalié et al., 1980; Orr, 1983). To test the mineral-matrix effect, all kerogens were analyzed by Rock-Eval pyrolysis (Table 4). The isolated kerogens reveal TOC contents that range from $24 \%$ to $70 \%$. The kerogen concentrate from the top of Unit IV presents the lowest TOC content $(23.78 \%)$, which is in accordance with the mean TOC content $(1.14 \%)$ of the whole-rock sample. The greatest amount of TOC $(70 \%)$ occurs in the kerogen concentrate from Sample 143-865A-90R-3, $110-111 \mathrm{~cm}$, which presented the highest TOC content for whole rocks.

Hydrogen indices for kerogen consistently present a slight increase, compared to HI-values for whole-rock samples, but a good correlation exists between the two for most samples (Fig. 19). Kerogen concentrates prepared from Samples 143-865-74R-1, 110-112 cm, and -92R$2,44-47 \mathrm{~cm}$, however, show an important increase of $\mathrm{HI}(80 \%)$, in comparison with their equivalent whole rocks. Retention of hydrocarbons by minerals in whole rocks certainly explains this difference.

Elemental analysis (C, H, N, O, S, and Fe) of kerogens reveals $2 \%$ to $54 \%$ pyrite-equivalent and low ash content (less than 5\%). Organic sulfur is relatively constant, with a $2 \%$ mean value. Carbon percent- ages in kerogen concentrates are in the same range as those estimated by Rock-Eval pyrolysis. The $\mathrm{H} / \mathrm{C}$ vs. O/C ratios are plotted in a van Krevelen diagram and compared with the Rock-Eval data (Fig. 20). As indicated in the van Krevelen diagram, an immature stage can be assigned to all samples from Hole $865 \mathrm{~A}$. A group of four points clusters in path III that has $\mathrm{H} / \mathrm{C}$ ratios of about 0.85 and $\mathrm{O} / \mathrm{C}$ ratios of about 0.34 . Two kerogens are located within path II, with one halfway between types II and III. The last one presents a very high $\mathrm{O} / \mathrm{C}$ ratio (0.39) for a relatively high $\mathrm{H} / \mathrm{C}$ ratio (1.27), which is related to the highest pyrite-content ( $54 \%$ ). Disturbance of $\mathrm{O}, \mathrm{C}$, and $\mathrm{H}$ percentages resulting from high pyrite content in kerogen is well known (Durand and Nicaise, 1980). This kerogen analysis has no meaning for organic matter characterization.

\section{Hole $866 \mathrm{~A}$}

To evaluate the type of organic matter, 13 samples exhibiting HIs from 130 to 784 were selected for kerogen concentration (Fig. 15).

Results from maceral analysis of 10 kerogen concentrates are reported in Table 3. Lamalginite and bituminite are the most important macerals. Lamalginite occurs as single, thin-walled bodies or, more commonly, forms algal or bacterial layers up to several millimeters long. Its fluorescent color is bright yellow to orange, and it exhibits strong positive alteration. The algal layers are accompanied by relatively strong fluorescing bituminite, which forms homogeneous layers or a fine network. We assumed that the bulk of this bituminite derived from degraded algae. Samples 143-866A-85R-3, 50-53 cm; -86R-1, $143-145 \mathrm{~cm}$, and $-86 \mathrm{R}-2,111-113 \mathrm{~cm}$ (795-805 mbsf) contain nearly exclusively these algal or bacterial layers and relatively strongly fluorescing bituminite ( $\mathrm{Pl} .2$, Figs. 3, 4). The $\mathrm{HI}$ values of these kerogens are high (about $750 \mathrm{mg} \mathrm{HC} / \mathrm{g}$ TOC).

The vitrinite content of the studied samples is generally low $(<5 \%)$. Only kerogens from Samples 143-866A-89R-1, 98-99 cm; -110R-1, $89-90 \mathrm{~cm}$; and $-118 \mathrm{R}-2,97-98 \mathrm{~cm}$, contain significant amounts (up to $35 \%$ ) of vitrinite beside lamalginite and bituminite. The occurrence of land plant-derived vitrinite agrees with the content of higher plantliptinite in two of these kerogens (Pl. 2, Fig. 5).

Some samples (i.e., 143-866A-110R-1, 89-90 cm, and -111R-1, $86-87 \mathrm{~cm}$ ) are characterized by especially high contents in weak 


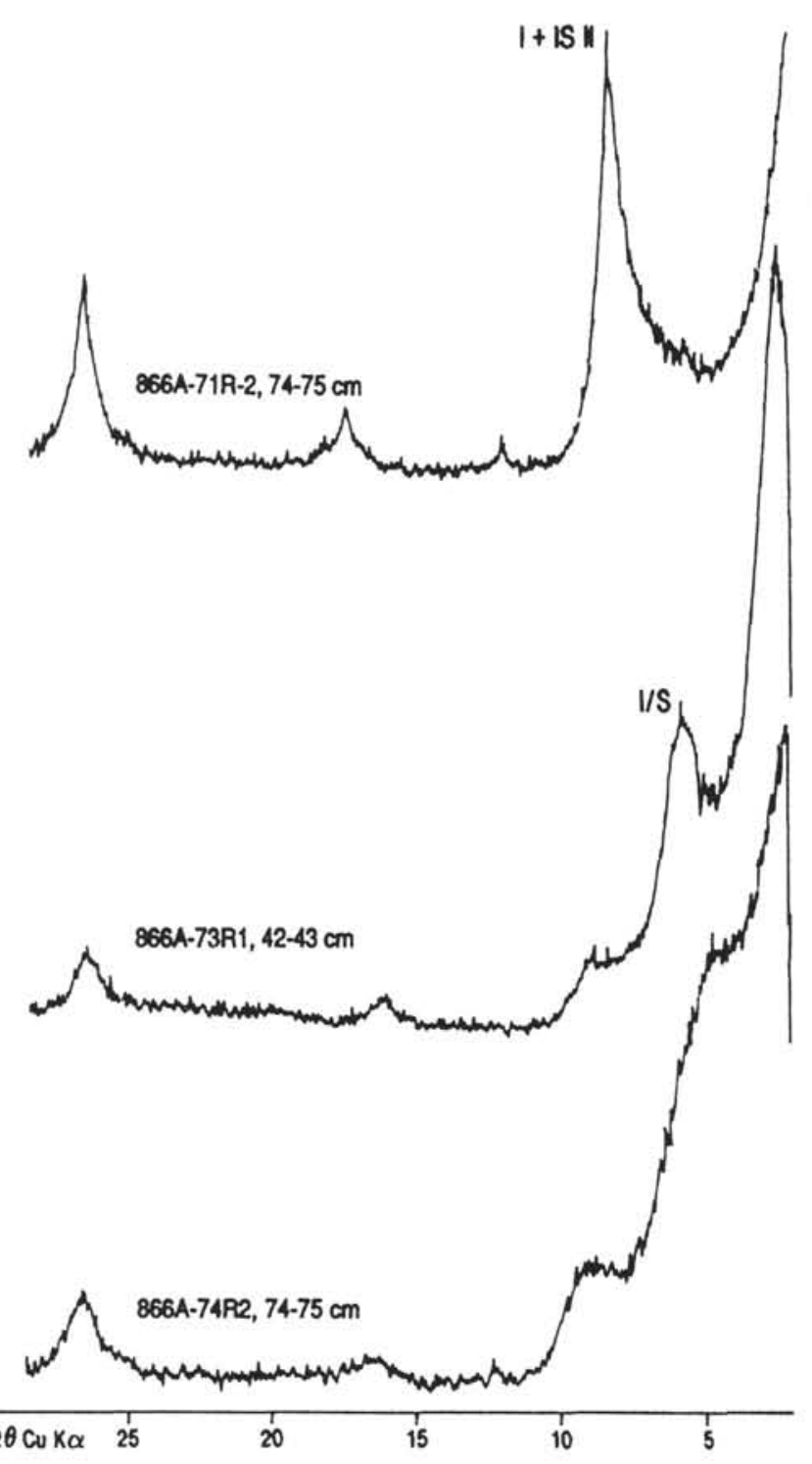

Figure 12. X-ray diffraction patterns (glycolated) of illite/smectite mixed-layers identified in Hole 866A.

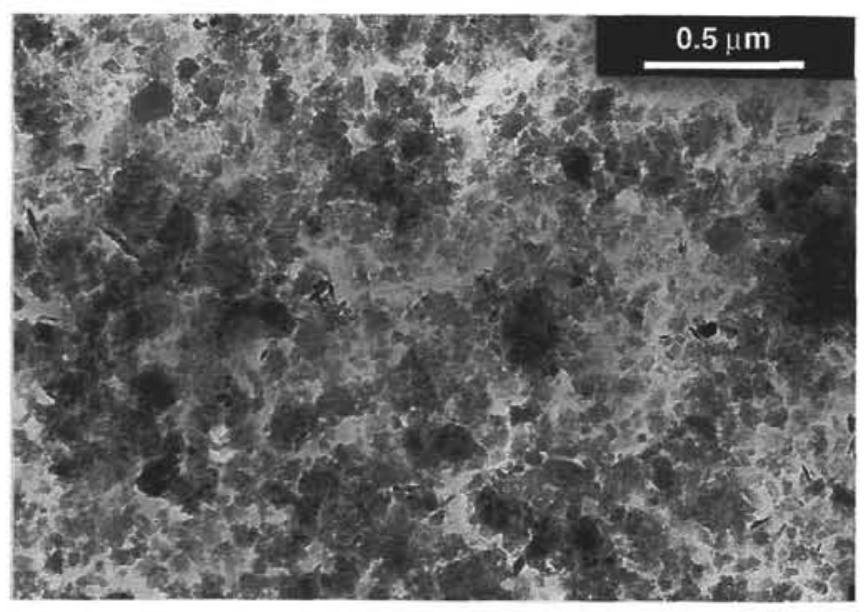

Figure 13. Transmission electron micrograph of the clay fraction of Interval 143-866A-71R-2, 67-71 cm.

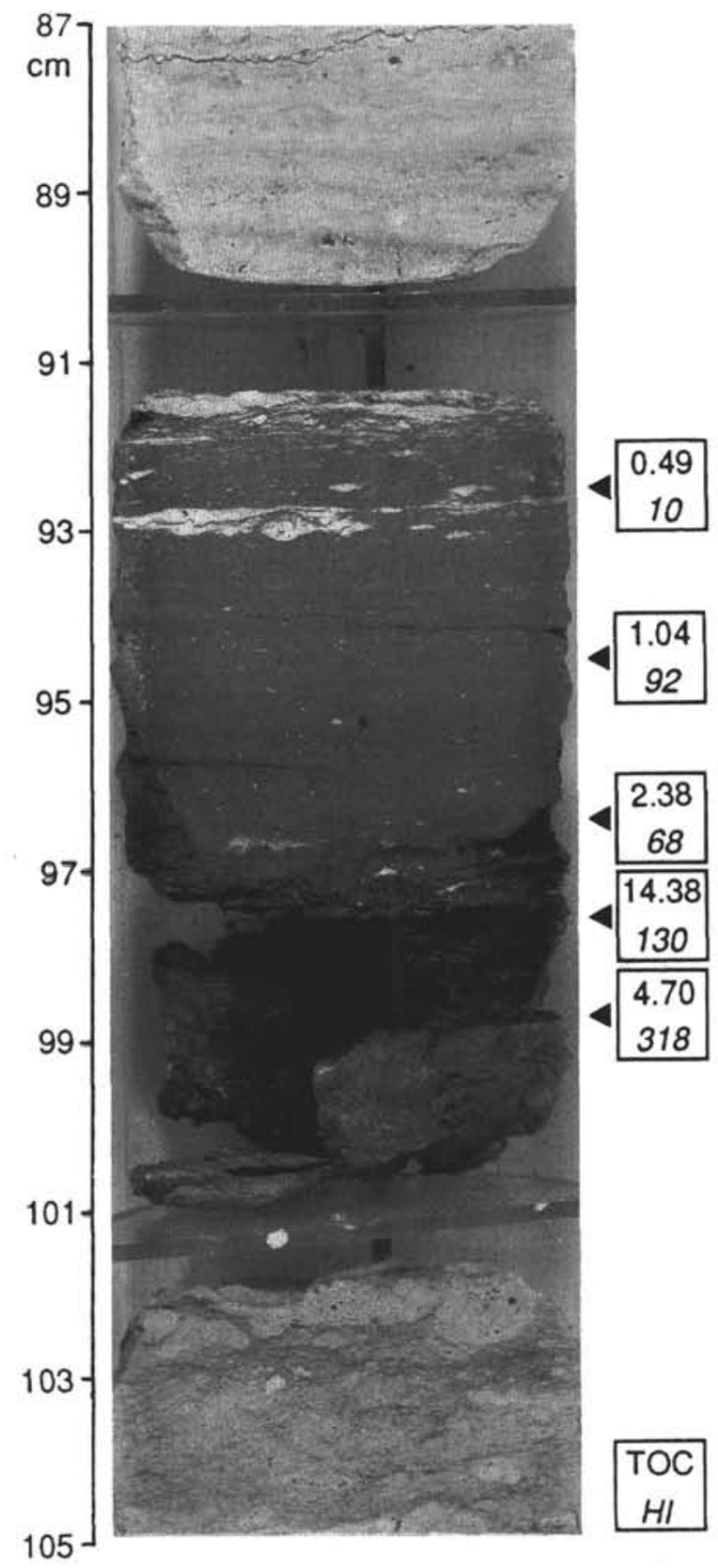

Figure 14. Photograph of Interval 143-866A-89R-1, 87-105 cm, showing dark green olive to black finely laminated shales of Aptian age. Higher-plant remains are abundant at the base of the dark facies. Total organic carbon content (\% TOC) and hydrogen index (HI, in mg hydrocarbons per $\mathrm{g}$ TOC) of studied samples are shown on the right.

fluorescing bituminite (Pl. 2, Fig. 6). The precursor of this bituminite variety, which displays a reflectance up to $0.34 \%$, is not known. Perhaps it is severely degraded algal material, or humic substances (Teichmüller and Ottenjann, 1977). Although these samples are rich in liptinites, they are characterized by relatively low HI values, indicating that the $\mathrm{HI}$ of weakly fluorescing bituminite is significantly lower than the HI of other liptinite macerals. Therefore, the correlation between $\mathrm{HI}$ and liptinite content is not as good as that for Hole 865A (Fig. 18).

Rock-Eval characterization of kerogen concentrates indicates a TOC content that varies from $21 \%$ to $65 \%$. The most deeply buried kerogen (at 1358.03 mbsf) has the lowest TOC content (Table 4). 
Table 4. Pyrolysis data, elemental composition, and ash content of kerogen concentrates from Holes 865A and 866A.

\begin{tabular}{|c|c|c|c|c|c|c|c|c|c|c|c|c|c|c|c|c|c|}
\hline $\begin{array}{l}\text { Core, section, } \\
\text { interval }(\mathrm{cm})\end{array}$ & $\begin{array}{l}\text { Depth } \\
\text { (mbsf) }\end{array}$ & $\begin{array}{c}\mathrm{CaCO}_{3} \\
(\%)\end{array}$ & $\begin{array}{l}\text { TOC } \\
(\%)\end{array}$ & $\begin{array}{l}T_{\max } \\
\text { (C) }\end{array}$ & HI & OI & $\begin{array}{l}\mathrm{C} \\
(\%)\end{array}$ & $\begin{array}{c}\mathrm{H} \\
(\%)\end{array}$ & $\begin{array}{c}0 \\
(\%)\end{array}$ & $\begin{array}{l}\mathrm{N} \\
(\%)\end{array}$ & $\begin{array}{l}\text { S tot. } \\
(\%)\end{array}$ & $\begin{array}{l}\mathrm{Fe} \\
(\%)\end{array}$ & $\begin{array}{l}\text { Ash } \\
(\%)\end{array}$ & $\begin{array}{l}\text { Pyrite } \\
(\%)\end{array}$ & $\begin{array}{c}\text { Sorg. } \\
(\%)\end{array}$ & $\mathrm{H} / \mathrm{C}$ & $\mathrm{O} / \mathrm{C}$ \\
\hline $\begin{array}{r}143-865 \mathrm{~A}- \\
74 \mathrm{R}-1,11\end{array}$ & & & & & & & & & & & & & & & & & \\
\hline $\begin{array}{l}74 \mathrm{R}-1,110-11 \\
90 \mathrm{R}-3,37-38\end{array}$ & $\begin{array}{l}680.80 \\
834.61\end{array}$ & $\begin{array}{l}68 \\
\text { n.d. }\end{array}$ & $\begin{array}{l}23.78 \\
36.49\end{array}$ & $\begin{array}{l}413 \\
404\end{array}$ & $\begin{array}{r}372 \\
65\end{array}$ & $\begin{array}{l}91 \\
73\end{array}$ & $\begin{array}{l}25.36 \\
52.35\end{array}$ & $\begin{array}{l}2.69 \\
3.84\end{array}$ & $\begin{array}{l}13.35 \\
24.74\end{array}$ & 0.43 & $\begin{array}{r}30.74 \\
8.24\end{array}$ & $\begin{array}{r}24.95 \\
5.97\end{array}$ & $\begin{array}{l}1.97 \\
4.43\end{array}$ & $\begin{array}{l}53.46 \\
12.79\end{array}$ & $\begin{array}{l}2.22 \\
1.42\end{array}$ & $\begin{array}{l}1.27 \\
0.88\end{array}$ & $\begin{array}{l}0.39 \\
0.35\end{array}$ \\
\hline $90 R-3,95-96$ & 835.19 & 56 & 61.67 & 405 & 145 & 34 & 55.87 & 4.16 & 25.73 & 0.55 & 7.12 & 4.07 & 2.50 & 8.72 & 2.46 & 0.89 & 0.34 \\
\hline $90 \mathrm{R}-3,110-111$ & 835.34 & 0 & 69.98 & 404 & 71 & 37 & 60.46 & 4.24 & 28.77 & 0.55 & 3.91 & 1.01 & 1.06 & 2.16 & 2.76 & 0.84 & 0.33 \\
\hline $90 \mathrm{R}-3,112-113$ & 835.36 & 0 & 33.33 & 409 & 123 & 66 & 43.24 & 3.08 & 20.51 & 0.56 & 16.98 & 12.43 & 3.20 & 26.63 & 2.77 & 0.85 & 0.36 \\
\hline $91 \mathrm{R}-5,130-132$ & 848.06 & n.d. & 51.81 & 427 & 839 & 28 & 57.78 & 6.93 & 14.36 & 0.59 & 10.77 & 7.57 & 2.00 & 16.22 & 2.11 & 1,44 & 0.19 \\
\hline $92 R-2,44-47$ & 849.07 & 0 & 33.41 & 422 & 399 & 51 & 41.57 & 3.63 & 14.77 & 0.61 & 21.12 & 16.82 & 1.48 & 36.04 & 1.90 & 1.05 & 0.27 \\
\hline $92 \mathrm{R}-2,58-60$ & 849.21 & 0 & 52.90 & 422 & 579 & 37 & 61.03 & 5.99 & 18.70 & 0.73 & 8.13 & 4.70 & 0.72 & 10.07 & 2.70 & 1.18 & 0.23 \\
\hline $\begin{array}{r}143-866 \mathrm{~A}- \\
56 \mathrm{R}-1,42\end{array}$ & 202 & 7 & & & & & & & & & & 28 & 6 & & 527 & 129 & 0.15 \\
\hline $58 \mathrm{R}-1,98-99$ & 531.98 & 97 & 53.39 & 403 & 60 & 56 & 55.13 & 6.68 & 14 & 1.5 & 7.92 & $\begin{array}{l}2.02 \\
1.82\end{array}$ & 12.49 & 3.90 & 5.84 & 1.45 & 0.19 \\
\hline $63 \mathrm{R}-2,109-111$ & 581.89 & n.d. & 54.05 & 416 & 417 & 62 & 57.93 & 6.08 & 20.24 & 1.67 & 8.12 & 1.96 & 5.60 & 4.20 & 5.88 & 1.26 & 0.26 \\
\hline $85 R-3,50-52$ & 795.25 & n.d. & 59.76 & 401 & 697 & 31 & 63.14 & 7.61 & 11.65 & 1.71 & 9.34 & 0.26 & 6.29 & 0.56 & 9.04 & 1.45 & 0.14 \\
\hline $86 \mathrm{R}-1,143-145$ & 802.93 & 79 & 64.91 & 416 & 749 & 19 & 65.86 & 8.07 & 12.09 & 1.13 & 8.18 & 1.17 & 3.50 & 2.51 & 6.84 & 1.47 & 0.18 \\
\hline $86 \mathrm{R}-2,111-113$ & 804.11 & n.d. & 59.23 & 417 & 821 & 26 & 63.89 & 8.23 & 10.26 & 1.21 & 10.75 & 3.36 & 2.30 & 7.20 & 6.91 & 1.55 & 0.16 \\
\hline $89 R-1,97-98$ & 831.57 & 25 & 59.42 & 410 & 183 & 50 & 56.92 & 4.67 & 20.72 & 1.07 & 8.42 & 3.83 & 4.37 & 8.20 & 4.04 & 0.98 & 0.27 \\
\hline $89 \mathrm{R}-1,98-99$ & 831.58 & 87 & 54.45 & 407 & 383 & 54 & 53.73 & 5.29 & 13.01 & 1.32 & 11.15 & 5.76 & 9.74 & 12.34 & 4.57 & 1.18 & 0.24 \\
\hline $110 \mathrm{R}-1,89-90$ & 1030.49 & 68 & 48.90 & 406 & 523 & 46 & 51.27 & 5.25 & 13.47 & 1.45 & 16.05 & 8.99 & 3.52 & 19.26 & 5.77 & 1.23 & 0.19 \\
\hline $111 \mathrm{R}-1,86-87$ & 1040.16 & n.d. & 56.25 & 410 & 500 & 39 & 59.89 & 6.16 & 14.61 & 2.30 & 10.78 & 3.78 & 2.48 & 8.10 & 6.46 & 1.23 & 0.25 \\
\hline 113R-CC, $44-45$ & 1058.94 & 53 & 40.49 & 410 & 584 & 30 & 41.41 & 4.93 & 9.56 & 0.93 & 22.43 & 15.34 & 5.40 & 32.87 & 4.90 & 1.43 & 0.17 \\
\hline 118R-2, 97-98 & 1109.27 & n.d. & 41.91 & 415 & 504 & 42 & 47.55 & 4.84 & 13.02 & 1.29 & 18.5 & 12.15 & 2.65 & 26.03 & 4.61 & 1.22 & 0.20 \\
\hline $144 \mathrm{R}-1,53-54$ & 1358.03 & 50 & 21.25 & 415 & 413 & 70 & 23.38 & 2.42 & 6.67 & 0.78 & 37.6 & 28.69 & 0.46 & 61.47 & 4.81 & 1.24 & 0.21 \\
\hline
\end{tabular}

Note: n.d. $=$ not determined.

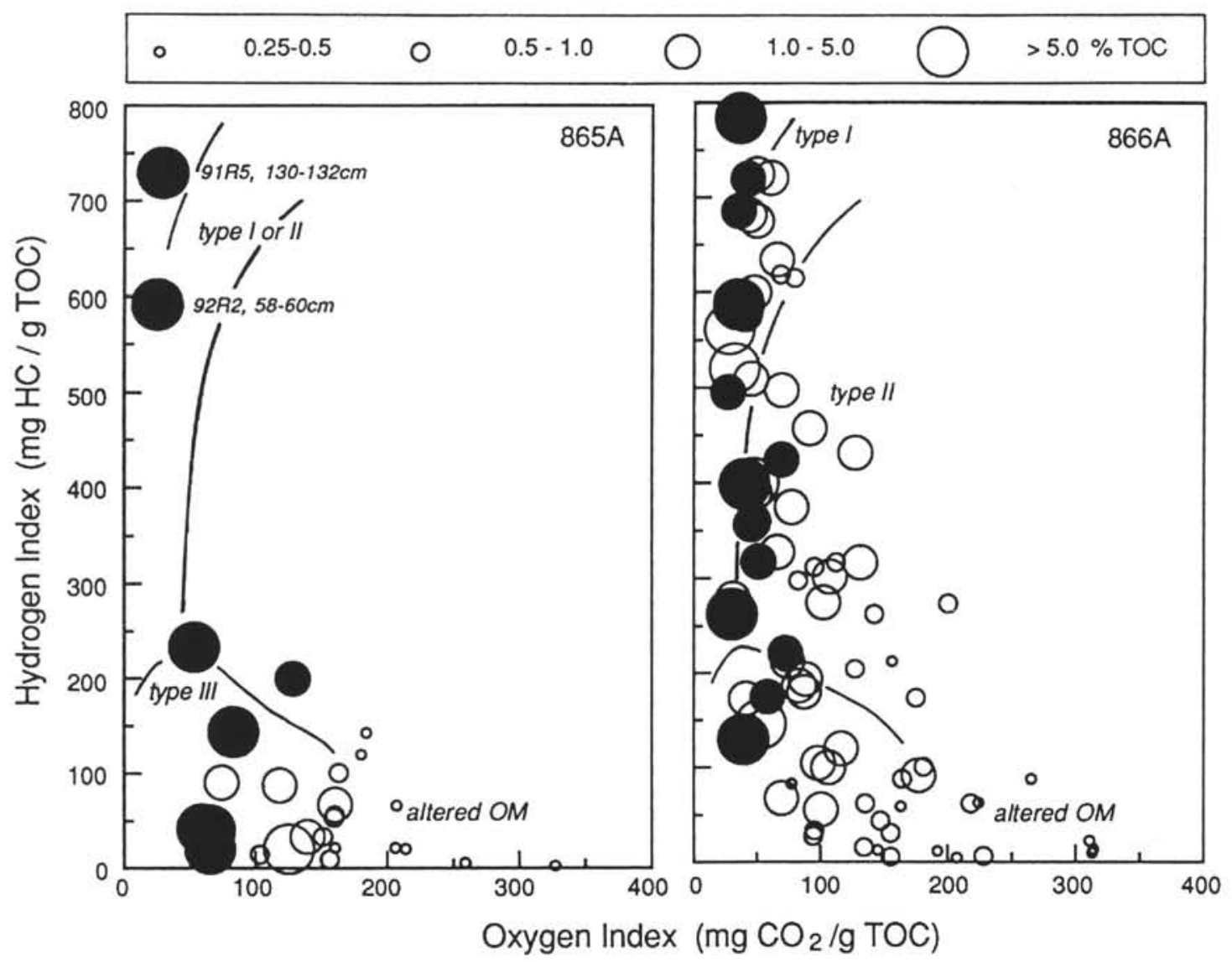

Figure 15. Hydrogen index (HI) vs. oxygen index (OI) diagrams for Holes 865A and 866A. Circles are proportional to total organic content (TOC, in wt\%). Note that black circles correspond to prepared kerogens. 


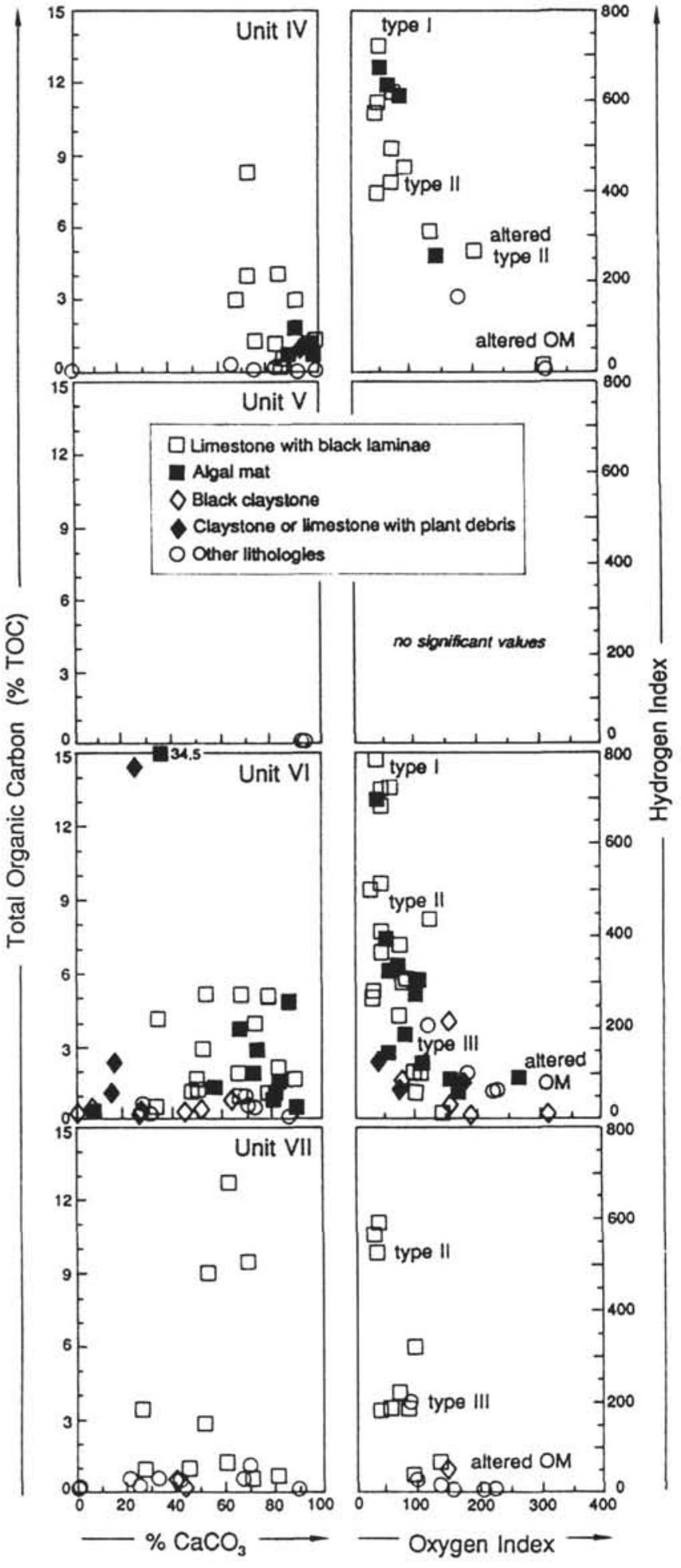

Figure 16. $\mathrm{CaCO}_{3}$-TOC and $\mathrm{HI}-\mathrm{OI}$ diagrams by unit and lithological characteristics of studied samples from Hole 866A.

Hydrogen indices of kerogen are always higher than the wholerock equivalent. Some samples (e.g., 143-866A-118R-2, 97-98 cm) present $\mathrm{HI}$ values that are twice as high for kerogen, implying a strong matrix effect (Fig. 19).

Measured $T_{\max }$ values on kerogen vary from $403^{\circ}$ to $417^{\circ} \mathrm{C}$. These are slightly lower than for whole rocks, but confirm the immature stage of the studied samples.

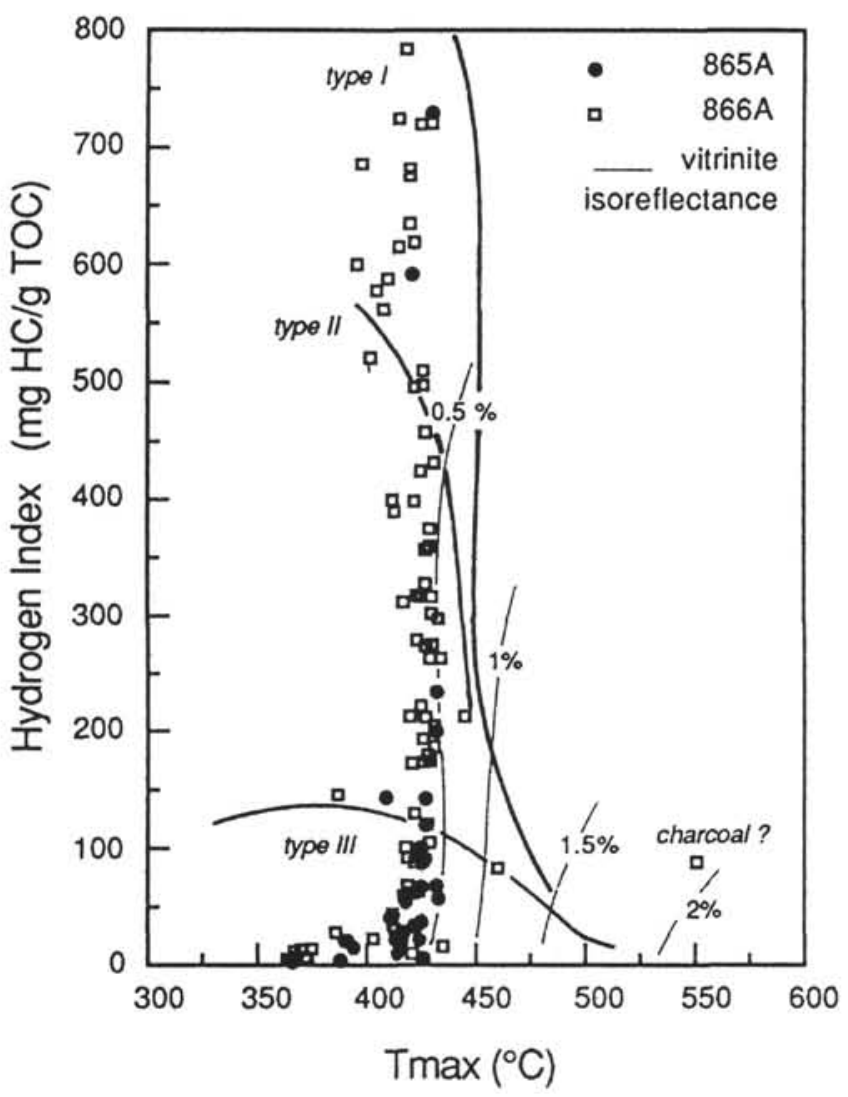

Figure 17. HI- $T_{\max }$ diagram for Holes $865 \mathrm{~A}$ and $866 \mathrm{~A}$.

Elemental analysis of kerogens reveals $0.5 \%$ to $6 \%$ of pyrite and relatively low ash amounts $(0.5 \%-6 \%)$, except for Samples 143 866A-58R-1, 98-99 cm, and -89R-1, 98-99 cm, which contain $12 \%$ and $10 \%$, respectively, of other minerals (Table 4). Carbon percentages determined by elemental analysis are slightly higher than those estimated by Rock-Eval pyrolysis, but a good correlation exists. Organic sulfur is relatively abundant $(4 \%-9 \%)$, and nitrogen also is more important here than in Hole $865 \mathrm{~A}$.

The $\mathrm{H} / \mathrm{C}-\mathrm{O} / \mathrm{C}$ diagram implies an immature stage of all the kerogen concentrates from Hole 866A (Fig. 20). The two samples from Core $143-866 \mathrm{~A}-89 \mathrm{R}$ show $\mathrm{H} / \mathrm{C}$ values of about 1 . Six kerogen concentrates are located along the type II evolution path, with $\mathrm{H} / \mathrm{C}$ ratios ranging from 1.22 to 1.29 . The others are related to the type I evolution path, with the highest $\mathrm{H} / \mathrm{C}$ ratios (1.43 to 1.55). No clear correlation exists between lithology and type of kerogen. For the same lithology, different samples present high (1.25) as well as very high (1.55) $\mathrm{H} / \mathrm{C}$ ratios. $\mathrm{O} / \mathrm{C}$ ratios are lower here than in Hole $865 \mathrm{~A}$ and fluctuate between 0.14 and 0.27 .

\section{Dichloromethane Extracts Study}

\section{Hole 865 A}

The bitumens collected from seven kerogen concentrates yielded 1.56 to $21.96 \mathrm{wt} \%$ of extract relative to TOC (Table 5). As is usually found in immature samples, N,S,O-compounds with high molecular weight predominate in the bitumens. Their amount ranges from $63 \%$ to $86 \%$ of the total extract, whereas saturates+unsaturates represent $3.9 \%$ to $28.3 \%$ and aromatic hydrocarbons, $5.9 \%$ to $9.7 \%$.

The molecular distribution in gas-chromatograms (Fig. 21A) must be considered carefully because of the relatively low saturates+ unsaturates fraction and the immaturity of the organic material.

Four samples present a small mode in the range of $\mathrm{C}_{17}$ to $\mathrm{C}_{19}$ and a predominance of odd-numbered $n$-alkanes in the $\mathrm{C}_{25}$ to $\mathrm{C}_{35}$ fraction. 


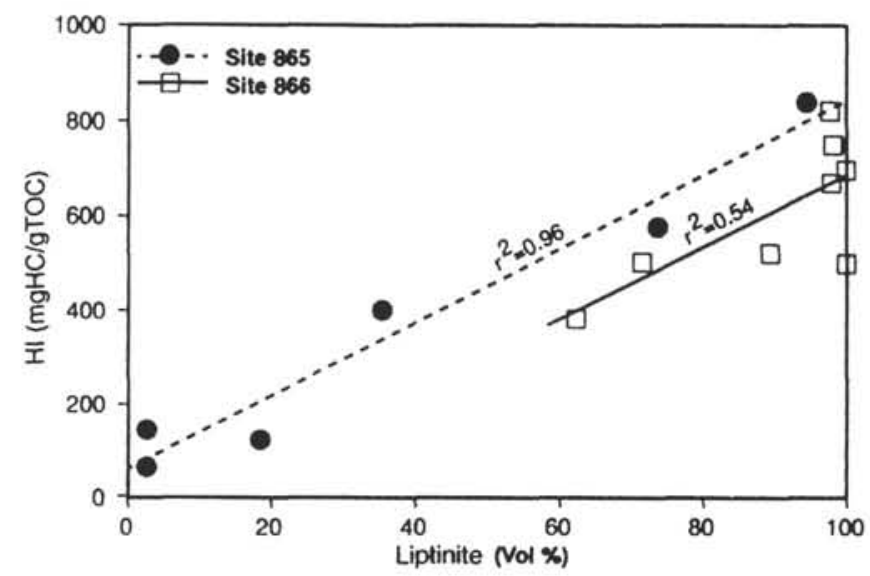

Figure 18. Relation between hydrogen index $(\mathrm{HI})$ of kerogen concentrates and content of organic matter in macerals of the liptinite group. There is a strong correlation in the case of Hole $865 \mathrm{~A}$ (correlation coefficient $r^{2}=0.96$ ), whereas the correlation is considerably weaker in the case of Hole $866 \mathrm{~A}\left(r^{2}=0.54\right)$.

Important amounts of $\mathrm{C}_{29}$ hydrocarbon, biomarkers, and relatively high carbon preference index (CPI between 2.64 and 3.42) were noted in these samples. The predominance of molecules having an odd number of carbon atoms can be measured by the CPI (i.e., the weight ratio of odd to even molecules; Tissot and Welte, 1984). All these characteristics correspond to an immature terrestrial organic material (Tissot and Welte, 1984), in agreement with the type III kerogen assignment.

Other samples present a bimodal distribution of hydrocarbons. The larger mode is in the range of $\mathrm{C}_{17}$ to $\mathrm{C}_{19} n$-alkanes, which suggests a phytoplanktonic origin, whereas the second mode corresponds to odd-number $n$-alkanes between $\mathrm{C}_{25}$ and $\mathrm{C}_{35}$. These chromatograms, associated with high $\mathrm{H} / \mathrm{C}$ ratios and $\mathrm{CPI}$ values below 1.9 , indicate a mixture of type I and III organic matter.

Three samples from the coaly interval in Section 143-865A-90R-3 present a large unresolved hump in the region of $\mathrm{C}_{35+}$ hydrocarbons. Clayton and Swetland (1978) showed that weathering of organic material results in a selective loss of $n$-alkanes and the lower carbon number molecules, producing a more pronounced envelope in the high molecular weights. We interpret the unresolved hump seen in some gas chromatograms as probably having been caused by weathering.

Isoprenoid amounts, mainly phytane and pristane, are very low to medium, ranging from $0.4 \%$ to $17 \%$.

\section{Hole 866A}

Only four kerogens from Hole $866 \mathrm{~A}$ yielded enough organic matter concentrate to be extracted (Table 5). The bitumen quantities range from $1.31 \%$ to $11.09 \%$ ext/TOC. High molecular compounds dominate the bitumens, with $75.5 \%$ to $94.5 \%$ of the total extract. The saturates+unsaturates fraction varies from $2.8 \%$ to $21 \%$, whereas aromatic hydrocarbons always represent less than $5 \%$.

Gas chromatograms (Fig. 21B) of Samples 143-866A-56R-1, $42-43 \mathrm{~cm}$, and $-118 \mathrm{R}-2,97-98 \mathrm{~cm}$, show a bimodal distribution. The first mode occurs at $C_{16}$ to $C_{18}$, with a slight predominance of evennumbered $n$-alkanes. The second mode occurs at $\mathrm{C}_{27}$ to $\mathrm{C}_{29}$, with a pronounced odd-number predominance that is typical of terrestrial organic matter. Although the $n$-alkane distribution of these samples, in many cases, is bimodal with a maximum at $\mathrm{C}_{27}$ to $\mathrm{C}_{29}$, the terrestrial organic matter contribution is thought to be overestimated owing to the immaturity of samples (Tissot and Welte, 1984).

Sample 143-866A-86R-2, 111-113 cm, presents an increasing percentage of $n$-alkanes from $\mathrm{C}_{16}$ to $\mathrm{C}_{25}$, with a slight predominance of odd numbers. Biomarkers, generally characteristic of autochthonous marine organic matter, are important in all three samples. They

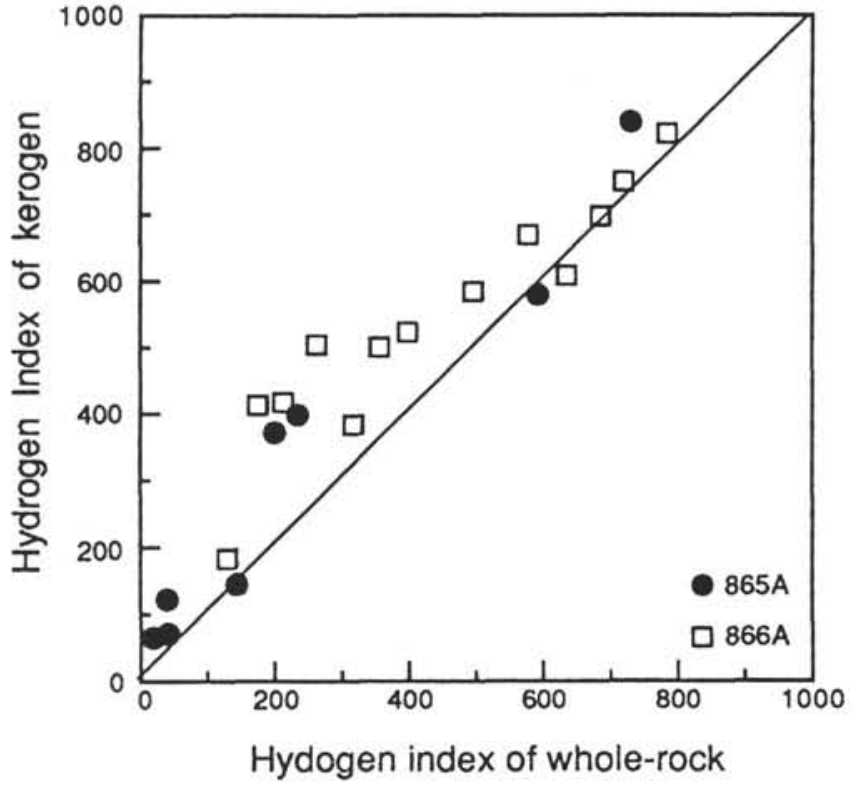

Figure 19. Relationship between $\mathrm{HI}$ of the whole-rocks and $\mathrm{HI}$ of kerogen concentrates, showing a slight matrix effect for some samples.

are minor in Sample 143-866A-89R-1, 97-98 cm, where $C_{17}$ to $C_{19}$ $n$-alkanes are dominant.

Pristane and phytane amounts are low, ranging from $0.7 \%$ to $5 \%$.

\section{Source of Organic Matter}

The question of the sources of organic matter is challenged by the problem of sampling. Sediments from Hole 865A are homogeneous enough over several centimeters in thickness to use the classical analytical methods. In the case of the laminated sediments in Hole $866 \mathrm{~A}$, however, it appears necessary to characterize the organic matter on the inframillimetric scale of the lamina, and great technical difficulties arise. In this study, the origin of organic matter has been characterized at a scale of centimeter-thick samples, which can contain tens of laminae.

\section{Hole $865 A$}

Most of the studied samples from Unit IV contain terrestrial organic matter. The abundance of dispersed carbonaceous debris, clearly visible roots in some cores, and prevalence of vitrinite in palynofacies indicate material derived from higher plants. Geochemical indicators also support the terrestrial origin. Hydrogen indices are generally low ( $<250 \mathrm{mg} \mathrm{HC} / \mathrm{g} \mathrm{TOC}$ ), and elemental analysis of kerogen situates the samples along the type III (terrestrial) evolution path (Tissot et al., 1974). The distribution of saturated hydrocarbons exhibits the predominance of odd-numbered $n$-alkanes in the $C_{25}$ to $C_{35}$ fraction, associated with a high CPI of about 3 . All these data suggest that higher plants were the principal source of the organic material preserved during the Albian at Allison Guyot. Nevertheless, this organic material underwent substantial alteration. The relatively low TOC content for plant-rich sediments and the presence of microcracks in coal particles indicate oxidation of the organic material during sedimentation or at the water/sediment interface. It is well known that accumulation rates of organic matter are relatively low when peats or tropical rain-forest soils are reworked and transported to the sea, because a high rate of decomposition exists. Because pyrite is generally abundant and unweathered in Unit IV, oxidation must have occurred before the organic particles passed through the zone of bacterial activity. 
Table 5. Composition of extracts from Holes $865 \mathrm{~A}$ and $866 \mathrm{~A}$ kerogen concentrates.

\begin{tabular}{|c|c|c|c|c|c|c|c|c|c|c|c|}
\hline $\begin{array}{l}\text { Core, section, } \\
\text { interval }(\mathrm{cm})\end{array}$ & $\begin{array}{l}\text { Depth } \\
\text { (mbsf) }\end{array}$ & $\begin{array}{l}\text { TOC } \\
(\%)\end{array}$ & $\begin{array}{c}T_{\max } \\
(\%)\end{array}$ & $\begin{array}{c}\text { Ext/TOC } \\
(\%)\end{array}$ & $\begin{array}{l}\text { Sat.+unsat. } \\
(\%)\end{array}$ & $\begin{array}{l}\text { Aro. } \\
(\%)\end{array}$ & $\begin{array}{l}\text { NSO } \\
(\%)\end{array}$ & $\begin{array}{l}\operatorname{Pr} \\
(\%)\end{array}$ & $\begin{array}{l}\mathrm{Ph} \\
(\%)\end{array}$ & $\mathrm{Pr} / \mathrm{Ph}$ & $\begin{array}{c}\text { CPI } \\
24-34\end{array}$ \\
\hline \multicolumn{12}{|l|}{$143-865 \mathrm{~A}-$} \\
\hline $90 \mathrm{R}-3,37-38$ & 834.61 & 36.49 & 404 & 5.78 & 27.22 & 9.66 & 63.12 & 4.22 & 8.90 & 0.47 & 2.64 \\
\hline $90 \mathrm{R}-3,95-96$ & 835.19 & 61.67 & 405 & 9.49 & 3.97 & 9.69 & 86.34 & 1.39 & 2.91 & 0.48 & 2.76 \\
\hline $90 \mathrm{R}-3,110-111$ & 835.34 & 69.98 & 404 & 1.56 & 8.76 & 9.50 & 81.74 & 9.45 & 16.28 & 0.58 & 1.54 \\
\hline $90 \mathrm{R}-3,112-113$ & 835.36 & 33.33 & 409 & 19.86 & 28.33 & 5.90 & 65.78 & 1.73 & 1.97 & 0.88 & 3.42 \\
\hline $91 \mathrm{R}-5,130-132$ & 848.06 & 51.81 & 427 & 21.96 & 8.23 & 5.96 & 85.81 & 2.76 & 3.69 & 0.75 & 1.45 \\
\hline $92 \mathrm{R}-2,44-47$ & 849.07 & 33.41 & 422 & 18.74 & 13.73 & 6.23 & 80.05 & 1.87 & 1.87 & 1.00 & 1.87 \\
\hline $92 \mathrm{R}-2,58-60$ & 849.21 & 52.90 & 422 & 5.54 & 22.36 & 6.41 & 71.24 & 0.44 & 0.73 & 0.60 & 2.97 \\
\hline \multicolumn{12}{|l|}{$143-866 \mathrm{~A}-$} \\
\hline $56 \mathrm{R}-1,42-43$ & 512.02 & 58.11 & 410 & 4.47 & 2.78 & 2.81 & 94.41 & 2.59 & 3.46 & 0.75 & 1.24 \\
\hline $86 \mathrm{R}-2,111-113$ & 804.11 & 59.23 & 417 & 11.09 & 8.02 & 5.35 & 86.63 & 0.24 & 0.72 & 0.34 & 1.39 \\
\hline $89 \mathrm{R}-1,97-98$ & 831.57 & 59.42 & 410 & 1.31 & 11.09 & 4.94 & 83.47 & 5.29 & 4.97 & 1.06 & 1.43 \\
\hline $118 \mathrm{R}-2,97-98$ & 1109.27 & 41.91 & 415 & 3.91 & 20.80 & 3.66 & 75.54 & 0.88 & 1.48 & 0.60 & 2.43 \\
\hline
\end{tabular}

Notes: Sat.+unsat. $=$ saturated and unsaturated hydrocarbons, Aro. $=$ aromatic fraction, $\mathrm{NSO}=$ heavy compounds, $\mathrm{Pr}=\mathrm{pristane}$, and $\mathrm{Ph}=$ phytane.
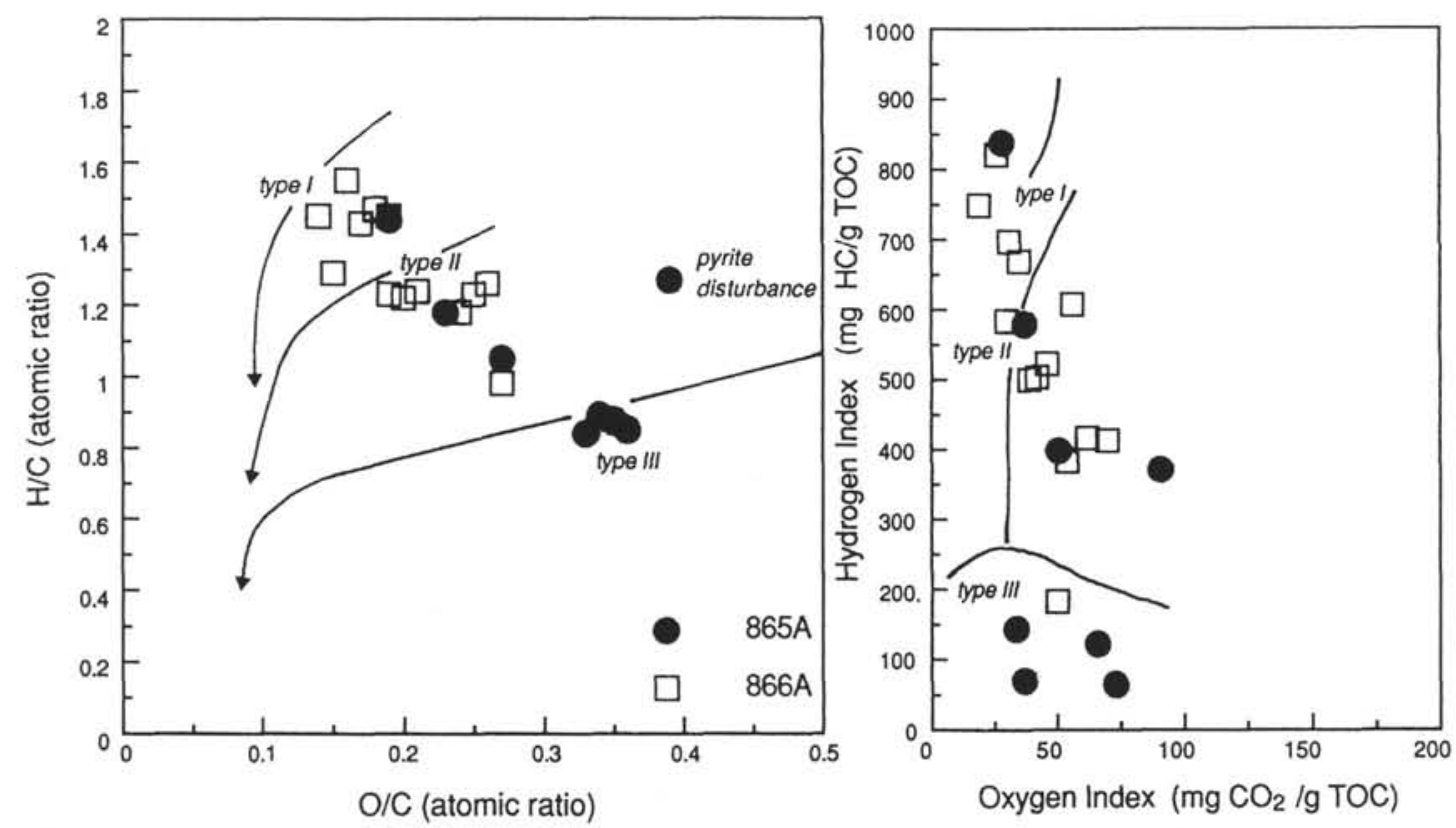

Figure 20. Location of kerogens selected from Holes $865 \mathrm{~A}$ and $866 \mathrm{~A}$ on a van Krevelen diagram (H/C vs. O/C atomic ratios), compared to the distribution of the same kerogens in an HI-OI diagram. The three reference evolution paths for types I, II, and III are reported following Tissot et al. (1974) for the van Krevelen diagram, and Espitalié et al. (1985a, 1985b, 1986) for the HI-OI diagram.

Two levels, however, indicate a different source of organic matter. Samples 143-865A-91R-5, 130-132 cm, and -92R-2, 58-60 cm, which correspond to a gray bioturbated wackestone and a black claystone, respectively, contain algal organic matter. High HIs (730 and $592 \mathrm{mg}$ $\mathrm{HC} / \mathrm{g} \mathrm{TOC})$, abundance of telalginite, high $\mathrm{H} / \mathrm{C}$ atomic ratios of the kerogen, and a large mode in the range of $\mathrm{C}_{17}$ to $\mathrm{C}_{19} n$-alkanes in the chromatograms indicate a type I (bacterial) or II (marine) organic matter. Thin-sections, which exhibit yellow organic particles, and palynological investigations suggest that the two samples contain a mixture of colonial algae, with minor terrestrial organic debris.

\section{Hole $866 \mathrm{~A}$}

With the exception of Core 143-866A-89R, the organic matter of Barremian to Aptian organic carbon-rich sediments from Hole $866 \mathrm{~A}$ has a marine primary source. Hydrogen indices that reach $800 \mathrm{mg}$ $\mathrm{HC} / \mathrm{g}$ TOC and high $\mathrm{H} / \mathrm{C}$ ratios indicate type I or II organic matter. Petrographical results show that lamalginite and bituminite are the most important macerals. Bituminite with weak fluorescence also was . ind and is considered to have been derived from several decayed algae or humic substances (Teichmüller and Ottenjann, 1977). Al- though the $n$-alkane distribution is bimodal, with a mode around $\mathrm{C}_{25}$ to $\mathrm{C}_{29}$, the terrestrial contribution is thought to be small. This is also supported by the conspicuously low abundance of vitrinite and inertinite macerals. Most of the organic matter preserved in Units IV, VI, and VII of Hole 866A derives from cyanobacterial mats and is more or less oxidized, as attested by decreasing TOC contents and HIs in some bioturbated samples.

Some samples, especially in Section 143-866A-89R-2, contain terrestrial organic matter. Higher plant contribution is here evidenced by core description (Shipboard Scientific Party, 1993), thin section observations, and petrographical investigations. Relatively low HIs (about $150 \mathrm{mg} \mathrm{HC} / \mathrm{g}$ TOC) associated with high TOC content, as well as low $\mathrm{H} / \mathrm{C}$ atomic ratios, are characteristic of terrestrial organic matter.

\section{Significance of Clay Minerals}

\section{Hole 865 A}

In Subunit IVD, the I/S are rich in smectite layers that have a magnesian composition. Examination of thin sections of basaltic sills indicates that the ferromagnesian minerals have been pseudomorphed by 

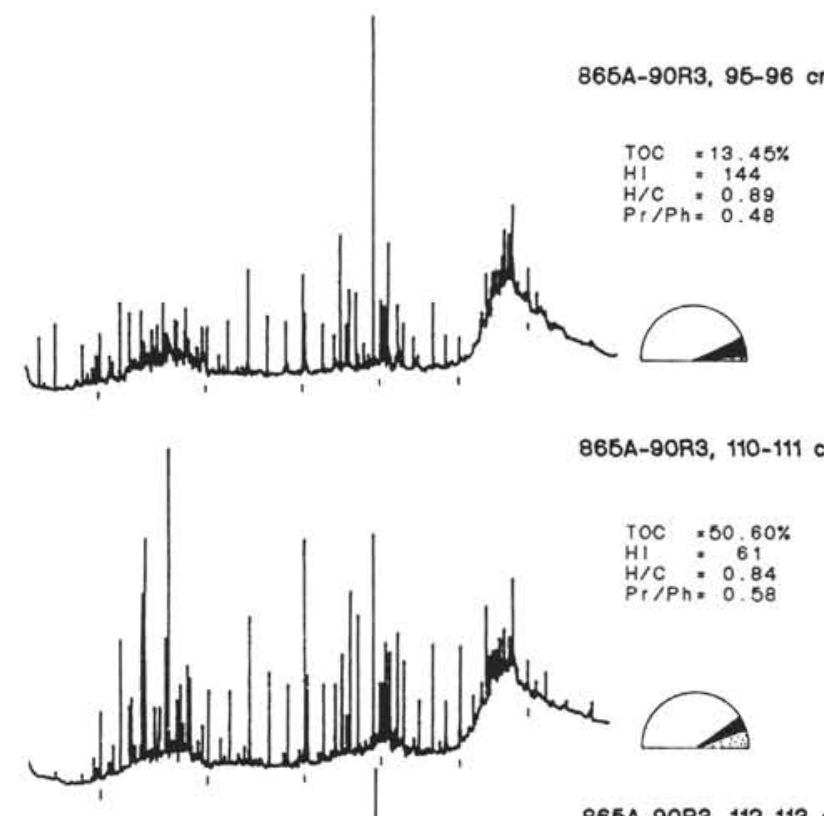

865A-90R3, 110-111 cm

865A-90R3, $112-113 \mathrm{~cm}$

$$
\begin{aligned}
& \text { TOC }=14.80 \% \\
& \text { HI }: 41 \\
& \text { H/C }: 0.85 \\
& \text { Pr/Ph }=0.89
\end{aligned}
$$
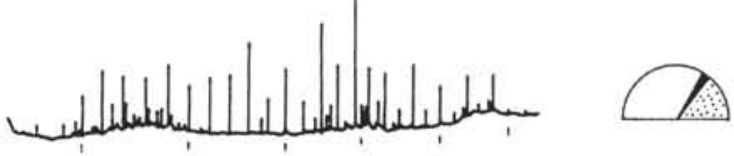

865A-91R5, $130-132 \mathrm{~cm}$
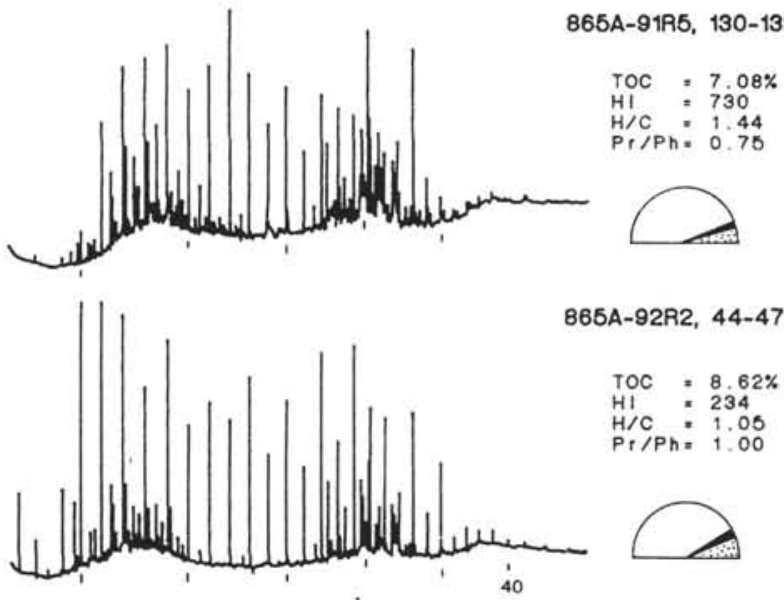

865A-92R2, $44-47 \mathrm{~cm}$

$$
\begin{aligned}
& \text { TOC }=8.62 \% \\
& \text { HI }: 234 \\
& \text { H/C }=1.05 \\
& \text { Pr/Ph }=1.00
\end{aligned}
$$
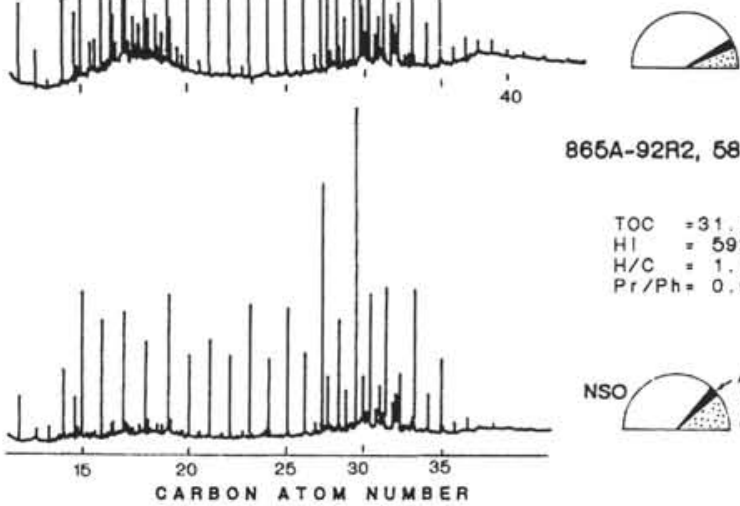

B65A-92R2, 58-60 cm

$$
\begin{aligned}
& \text { TOC }=31.11 \% \\
& \text { HI }=592 \\
& \text { H/C }=1.18
\end{aligned}
$$

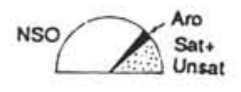

Figure 21. A. Gas chromatograms of selected samples from Unit IV of Hole 865A. B. Gas chromatograms of selected samples from Hole 866A. Half pie-graphs show the proportion of the different fractions of the bitumen. Sat+unsat $=$ saturated and unsaturated hydrocarbons, Aro $=$ aromatic fraction, NSO $=$ heavy compounds, $\mathrm{Pr}=$ pristane, and $\mathrm{Ph}=$ phytane. 
clay minerals and that glass has now been converted to clay (Shipboard Scientific Party, 1993). In the ocean floor, sediments interbedded with or deposited just above basalt commonly contain abundant $\mathrm{Mg}$-rich smectite coming from the weathering of the volcanic rock (Chamley, 1989). A similar origin is highly probable for the sediments of Subunit IVD. In Subunit IVC, the amounts of I/S diminish because of the decreasing volcanic influence. At the base of the subunit, I/S are still abundant, but contain more illite layers here than in Subunit IVD, suggesting another origin. The occurrence of terrestrial plant debris (abundant type III organic matter) points to the erosion of nearby islands. In this context, I/S from the base of Subunit IVC may be partly detrital. The detrital influences also are expressed by increasing percentages of kaolinite. This mineral, which occurs together with gibbsite, also indicates hydrolyzing (warm and humid) climatic conditions. In Section 143-865A-89R-2, illite and 1:1 layer minerals (including kaolinite and berthierine) increase, whereas I/S strongly decrease. The coeval increase of detrital illite and kaolinite suggests a strong erosion of nearby land areas, but, surprisingly, TOC (mainly type III) decreases. This can result from either oxidation of organic matter in the marine environment or dilution of organic matter by clastic sediments eroded from islands. Oxidizing conditions are evidenced by the occurrence of berthierine. In modern sediments, this ferric iron-rich mineral occurs in shallow (water depth of about $50 \mathrm{~m}$ ), well-oxygenated coastal environments. This mineral, which is restricted to tropical areas and commonly associated with kaolinite, is very common in most oolitic ironstones (Odin and Matter, 1981; Debrabant et al., 1992). According to laboratory experiments, early diagenetic remobilization of iron initiates transformations of detrital kaolinite to berthierine (Bhattacharrya, 1983).

In Subunit IVB, the decrease of illite and kaolinite is balanced by an increase of I/S and probably suggests less erosion, which may be the result of the progressive submersion of the volcanic islands.

\section{Hole $866 \mathrm{~A}$}

A detrital origin of chlorite and kaolinite is likely. Small amounts of these minerals point to weak detrital influxes, which also are evidenced by the occurrence of organic matter of marine, instead of terrestrial, origin. In most sediments that have not undergone deep burial, illite is considered as detrital and shows fluctuations parallel to chlorite or kaolinite (Chamley, 1989; Deconinck, 1992). As indicated by the occurrence of immature organic matter and smectite-rich $\mathrm{I} / \mathrm{S}$, the influence of thermal diagenesis is negligible in Hole 866A. Nevertheless, some observations suggest that illite is not entirely detrital. Variations in the percentages of illite are not parallel to those of chlorite and kaolinite. Chemical analyses point to an iron-rich composition, and TEM observations reveal the small sizes of the illitic material, whereas detrital illites usually exhibit aluminum composition and commonly occur as relatively large particles. Illitic material showing similar X-ray and chemical features already has been described in lacustrine sediments (Porrenga, 1968; Newman and Brown, 1987), in paleosoils (Robinson and Wright, 1987), and in the clay fraction from green marls occurring at the top of upwardshallowing sequences of Lower Cretaceous carbonate platforms in the Tethyan realm (e.g., Purbeckian platform: Deconinck and Strasser, 1987; Deconinck et al., 1988). The formation of illitic minerals probably occurs at surface temperatures in potassium-rich supratidal environments, where smectites and smectite-rich I/S are submitted to wetting and drying cycles. Laboratory experiments have shown that smectites submitted to such cycles are progressively transformed into I/S (Srodon and Eberl, 1984; Eberl et al., 1986). Ordered and random I/S, which occur in some samples, correspond to incomplete transformation of smectite. The origin of smectite that constituted the father mineral is more difficult to establish.

\section{Depositional Conditions}

\section{Hole $865 A$}

Facies analysis of Subunit IVD at Hole $865 \mathrm{~A}$ indicates that the deepest sediments recovered at Allison Guyot corresponded to shal- low-marine environments. Locally, brackish-waters environments or stagnant marine-water pools certainly have existed, favoring the development of colonial algae, as shown in Cores 143-865A-92R and -91R. At the base of Subunit IVC (Cores 143-865A-90R and -89R), abundant terrestrial organic matter, roots in growth position, and relative paucity of fauna indicate more restricted environments, such as a marsh. A humid climate, favoring coastal vegetation and intense runoff, probably dominated at that time. Soil-derived materials, including $\mathrm{I} / \mathrm{S}$, kaolinite, and terrestrial organic matter, were probably supplied from volcanic islands. Higher-plant debris was partially oxidized before it was transported into the swamp, as attested by cracks in the vitrinite particles and relatively low TOC amounts of the carbonaceous-rich facies. This land-derived influx became less abundant upward and disappeared within Subunit IVB, suggesting that the volcanic edifice was progressively submerged at that time. The progressive disappearance of terrestrial organic matter runs parallel to an increase of OIs, which suggests that more oxygenated platform conditions, unsuitable for organic matter preservation, prevailed during the time Subunits IVB and IVA were deposited. The water certainly was oxygenated enough to sustain the infaunal activity, clearly demonstrated by abundant fossils and the intense bioturbation of the sediment.

The presence of pyrite associated with organic matter implies important bacterial sulfate reduction during the time of deposition of Subunits IVD and IVC. Gas chromatography results show that the phytane generally predominates over pristane in all samples from Hole $865 \mathrm{~A}$. It is well known that the depositional paleoenvironment can influence the formation of isoprenoids issuing from phytol (Tissot and Welte, 1984). The richness in phytane should indicate a restricted environment, suitable for organic matter preservation, whereas pristane predominance indicates unfavorable conditions for preservation of organic matter (Brooks et al., 1969; Didyk et al., 1978). Pristane:phytane ratios become reliable indicators of the environment only in the early mature zone, where phytanic acid has become more or less converted to pristane. Recent studies have shown multiple sources for precursors of pristane and phytane and have questioned the use of pristane:phytane ratios as redox indicators (Goossens et al., 1984; ten Haven et al., 1987). The predominance of phytane in samples from Hole $865 \mathrm{~A}$ may be here regarded as a consequence of too low maturation, rather than a clear indication for a reducing environment. However, reducing environmental conditions existed at least during the deposition of alginite-rich sediments from Cores 143 $865 A-92 R$ and $-90 R$.

\section{Hole 866 A}

Sequence-stratigraphic analysis of the sediments at Hole 866A (Arnaud et al., this volume; Strasser et al., this volume) suggests that the clay- and organic-rich facies were mainly deposited during lagoonal to peritidal phases of the history of Resolution Guyot.

Comparison of geochemical data with petrographic analyses clearly shows that the density and thickness of laminae increase in samples having high TOC contents. As a general rule, the more important the organic content, the more continuous are the laminae. On the other hand, when ligneous fragments and dispersed brown algae predominate, TOC contents are low.

Several centimeter-thick organic-rich layers present a sharp increase of organic carbon content and $\mathrm{HI}$ from bottom to top. This upward increase probably was caused by flooding of the depositional site and better preservation of the organic matter under anoxic conditions. Only interval $143-866 \mathrm{~A}-89 \mathrm{R}-1,92-100 \mathrm{~cm}$, presents a reverse trend with an upward decrease of organic content. Total organic carbon percentages pass from $14.38 \%$ at the base to $0.49 \%$ at the top (Fig. 14). This interval contains mainly terrestrial organic matter, which generally display a strong heterogeneity in organic content. But in this case, probable subaerial alteration induced an upward decrease in TOC content and HI.

The existence of planktonic organisms, such as coccoliths and foraminifers, at Hole $866 \mathrm{~A}$ indicates oxygenated surface waters with 
access to the open-marine environment, at least during some time intervals. This strongly suggests that the water column was not anoxic, but that the redox boundary lay at, or close to, the water/sediment interface and probably in the cyanobacterial mat itself. Environmental signification of $\mathrm{Pr} / \mathrm{Ph}$ ratios is doubtful, owing to the low quantity of these isoprenoids and the weak maturity of the studied samples. Nonetheless, a general tendency of reducing environments is shown by low $\mathrm{Pr} / \mathrm{Ph}$ ratios in algal or cyanobacterial mats, whereas a more oxygenated environment is recorded in Sample 143-866A$89 \mathrm{R}-1,97-98 \mathrm{~cm}$, rich in terrestrial organic matter.

The high organic sulfur content, characteristic of the organic matter from Hole $866 \mathrm{~A}$, is probably the result of intense bacterial sulfate reduction associated with low amounts of reactive iron in interstitial waters. Sulfate-reducing bacteria depend on a continuing supply of simple organic acids derived from the activities of heterotrophic bacteria (Kenig and Huc, 1990). Hydrogen sulfide in turn is poisonous, and continuing degradation of organic matter depends on the removal of hydrogen sulfide by reactive iron oxides. When reactive iron contents are low, sulfur is incorporated into organic matter, and the residual organic matter has a high content of organic sulfur (Berner, 1984; Gautier, 1986).

No direct evidence is available regarding the temperatures and salinities of the waters. Only indirect hypotheses may be formulated from the existence of cyanobacterial mats that point to relatively warm waters, such as exist today in Shark Bay (western Australia), Laguna Guerrero Negro (Mexico), Solar Lake (Red Sea), and Abu Dhabi lagoons (United Arab Emirates). The water temperature reported for Shark Bay is between $18^{\circ}$ and $28^{\circ} \mathrm{C}$. Salinities associated with present algal or cyanobacterial mats are higher than in normal seawater (i.e., hypersaline in Solar Lake; Krumbein et al., 1977), and 40 to $70 \%$ in Abu Dhabi (Kenig et al., 1990; Kenig, 1991). On Resolution Guyot, evaporite pseudomorphs in several levels point to recurrently hypersaline conditions, but they are not consistently associated with microbial mats (Arnaud et al., this volume). Normal saline conditions may also support cyanobacterial mats, as mentioned by Glikson and Taylor (1986).

\section{Comparison of DSDP Site 463 with Hole 866A}

DSDP Site 463, drilled during Leg 62 (Thiede, Vallier, et al., 1981), is located $44.4 \mathrm{~km}$ northeast of Site 866 (Fig. 1) and represents a part of the basinal sequence correlated to platform limestones encountered on Resolution Guyot (Shipboard Scientific Party, 1993).

Three beds of siliceous limestone containing between $2 \%$ and $7 \%$ organic carbon occur between Cores 62-463-69 and -72 within the lower Aptian sequence. The most remarkable structures in these cores are laminations in the dark gray clayey intervals intercalated in bluish-white to dark greenish-gray limestones. The thicknesses of the laminated intervals range from a few centimeters to more than $60 \mathrm{~cm}$. The darker intervals are especially abundant in Cores 62-463-70 and -71 , but they are difficult to distinguish from volcanic-ash layers. These facies do not display evidence of emplacement by turbidity currents (Thiede, Vallier, et al., 1981). They are mainly strongly silicified limestones, with some chert and volcanic-ash layers. Radiolarians are abundant, but poorly preserved, compared to the radiolarians above and below (Schaaf, 1981). This suggests that the silica for the diagenetic silicification of the limestone was, at least partly, biogenic; hence, possibly the surface water was highly fertile. Only three levels contain high organic carbon concentrations that reach 7\% TOC (Dean et al., 1981; Mélières et al., 1981). Hydrogen indices generally are low $(<100)$, but some samples show higher values (up to 571 ), suggesting a type II or a mixture between type II and III organic matter (Mélières et al., 1981). As expected, the proportion of marine organic matter increases with increasing concentrations of organic carbon.

Occurrences of carbonized plant debris in lower Aptian sediments at Site 463 (Timofeev and Bogolyubova, 1981; Mélières et al., 1981) and in a 80-cm-thick bed of upper Aptian gray claystones at Site 462 in the Nauru Basin (Jenkyns and Schlanger, 1981) suggest a considerable influx of terrestrial organic matter from nearby land areas.

Resolution Guyot, which was the nearest island during Early Cretaceous time, was certainly the source of the terrestrial organic matter encountered at DSDP Site 463. The intermittent occurrence of some lignitic fragments in Barremian to Aptian sediments in Hole $866 \mathrm{~A}$ attests that terrestrial organic matter occasionally was transported into the platform's interior. Seaward transport of plant debris may also have occurred at the same time.

At Site 463, the clay fraction of Barremian and Aptian sediments is composed of random I/S, smectite, and illite with common clinoptilolite (Nagel and Schumann, 1981; Rateev et al., 1981). Smectite and smectite-rich I/S developed from abundant volcanic material, including basaltic glass and ash layers. Such an origin is doubtful at Site 866 , where sediments were deposited in a different sedimentary environment and where volcanic material is not described as being abundant. Small volcanic particles were noted in Cores 143-866A$89 \mathrm{R}$ to $-87 \mathrm{R}$ (Arnaud et al., this volume), and some zeolite and feldspar minerals in Core 143-866A-88R (Shipboard Scientific Party, 1993a, 1993b) indicate volcanic influences at that time.

The organic-rich sediments recovered from Cores 143-866A-85R to $-89 \mathrm{R}$ are possibly the equivalent of the late early Aptian organicrich sediments at Site 463, even if an intense volcanic activity is not recorded on Resolution Guyot from that time. At the same time interval, deposition of marine and terrestrial organic matter took place at both sites.

Organic carbon-rich sediments recovered in Subunit VIA of Hole $866 \mathrm{~A}$ are the first evidence of shallow-water anoxic environments of this age in the Pacific Ocean. A widespread anoxic event is well known in numerous DSDP sites from the Pacific (Schlanger and Jenkyns, 1976; Sliter, 1989) as well as in the Tethyan realm with the Selli level from Italy (Coccioni et al., 1987), or the Goguel level from southeast France (Bréhéret, 1988; Weissert and Bréhéret, 1991). The probability that the Selli event has been recorded on Resolution Guyot also is supported by $\mathrm{C}$-isotopic stratigraphy (Jenkyns, this volume).

\section{SUMMARY AND CONCLUSIONS}

1. Very low to low organic carbon content characterizes gray green pyritic claystones and most of the bioturbated clayey wackestones and packstones in Hole 865A. The richest samples (6\%-50\% TOC) correspond everywhere to black and brown claystones, whereas some coaly claystones and packstones show mean organic content of around $1 \%$ or less. TOC percentages in Hole $866 \mathrm{~A}$ present high-amplitude variations that range from $0.1 \%$ to $34.5 \%$. As a general rule, TOC contents higher than $3 \%$ are recorded in laminated limestones, algal mats, and claystones with plant debris, whereas gray limestones, sandy claystones, and green clay layers have TOC contents lower than $0.5 \%$.

2. Microscopic and geochemical investigations indicate that type III organic matter, of terrestrial origin, characterizes the Albian claystones at Hole 865A. Nevertheless, two samples from the bottom of the hole contain alginite-rich organic matter related to types I or II, with HIs up to $730 \mathrm{mg} \mathrm{HC} / \mathrm{g}$ TOC. In Hole $866 \mathrm{~A}$, the organic matter from Barremian to Aptian sediments is widely distributed between type I (bacterial or algal) and type IV (altered), according to the wide range of $\mathrm{HIs}$ (5-784 mg HC/g TOC). Laminated limestones and algal mats clearly show the highest HIs and are related to type I or II organic matter. Black claystones and clays with plant debris show low to medium HIs (50-200), suggesting a type III organic matter. Other lithologies generally have low HI values and high OI values, indicating type IV organic matter. Vitrinite is less common in Hole 866 A than in Hole $865 \mathrm{~A}$, but variable amounts occur over a wide depth range, indicating the existence of nearby land with vegetation until at least Aptian time.

3. Maturation levels below the oil window were found throughout the Lower Cretaceous sediments in both holes. Considering the shallow burial depth, relatively high vitrinite reflectance may be a 
consequence of a local thermal perturbation caused by basaltic sills in Hole $865 \mathrm{~A}$. High $T_{\max }$ values suggest a probable charcoal content in some samples from Hole $866 \mathrm{~A}$.

4. The composition of clay-mineral assemblages results from various early diagenetic, volcanic, and detrital influences during the evolution of Early Cretaceous sedimentary environments of Allison and Resolution guyots. Early diagenetic changes are responsible for the replacement of detrital kaolinite by berthierine in oxidizing conditions (Hole 865A, Subunit IVC). Sediments of Hole 866A are characterized by the occurrence of illitic minerals that resulted from the replacement of smectitic minerals submitted to wetting and drying cycles at surface temperatures.

Volcanic influences are particularly well expressed at the base of Hole $865 \mathrm{~A}$, where smectite-rich $\mathrm{I} / \mathrm{S}$ originated from the weathering of basaltic rocks.

Significant detrital components are recorded at Hole 865A, where kaolinite associated with terrestrial organic matter is abundant and reflects active erosion of the nearby land area. The decrease of illite and kaolinite, balanced by increasing amounts of I/S, in Subunit IVB probably results from the progressive submersion of volcanic islands. By contrast, the scarcity of kaolinite and the occurrence of marine organic matter in Hole $866 \mathrm{~A}$ point to a more gentle terrestrial erosion.

5. Marshy environments probably existed during Aptian/early Albian time on Allison Guyot. The humid climate favored growth of coastal vegetation and intense terrestrial run-off. Such environments were suitable to deposition of terrestrial organic matter, whereas local quiet pools supported the development of abundant colonial algae. The land-derived organic matter was progressively more oxidized and became less abundant with the progressive submergence of the volcanic edifice and the replacement of the marshes by shallowwater platform.

During the stage of active carbonate platform growth on Resolution Guyot, the platform stayed at or near sea level, allowing for the deposition of lagoonal to peritidal organic-rich facies. These facies are mainly represented by finely laminated limestones and cyanobacterial mats. Terrestrial organic matter occurs here and there throughout the lagoonal and peritidal facies and is testimony to the existence of vegetated islands.

6. Comparison of Hole 866 A with DSDP Site 463 reveals that Resolution Guyot was the source of the detrital organic matter redeposited at Site 463 during early Aptian time. Organic-rich facies from Subunit VIA probably correlate with the Oceanic Anoxic Event of this age.

\section{ACKNOWLEDGMENTS}

The authors are grateful to ODP for inviting three of us to participate in Leg 143. We are indebted to IFP and KFA for analytical facilities. HA, FB, and JFD acknowledge the French "Géosciences Marines" program for financial support. RFS thanks the Alexander von Humboldt Foundation its granting of a research fellowship. AS acknowledges the support of the Swiss National Science Foundation. The authors thank W. Riegel (Göttingen) for palynological help. The manuscript benefitted from the critical comments of R. Moberly, P. Meyers, and E.L. Winterer.

\section{REFERENCES}

Bailey, S.W., 1980. Structures of layer silicates. In Brindley, G.W., and Brown, G. (Eds.), Crystal Structures of Clay Minerals and Their X-ray Identification. Mineral. Soc. London Monogr., 5:1-124.

Baudin, F., and Téhérani, K., 1991. Faciès organique et maturation thermique du Lias supérieur de la Formation de Shemshak (Elbourz central, Iran). Eclogae Geol. Helv., 84:727-738. Abbreviations for names of organizations and publications in ODP reference lists follow
the style given in Chemical Abstracts Service Source Index (published by American Chemical Society).
Belin, S., 1992. Distribution microscopique de la matière organique disséminée dans les roches-mères. Technique d'étude. Interprétation des conditions de dépôt et de diagenèse [Ph.D. thesis]. Orsay Univ.

Berner, R.A., 1984. Sedimentary pyrite formation: an update. Geochim. Cosmochim. Acta, 48:605-615.

Bhattacharrya, D.P., 1983. Origin of berthierine in ironstones. Clays Clay Miner., 31:173-182.

Bréhéret, J.-G., 1988. Episodes de sédimentation riches en matière organique dans les marnes bleues d'âge Aptien et Albien de la partie pélagique du Bassin Vocontien. Bull. Soc. Geol. Fr., 8:349-356.

Brooks, J.D., Gould, K., and Smith, J.W., 1969. Isoprenoid hydrocarbons in coal and petroleum. Nature, 222:257-259.

Brown, G., and Brindley, G.W., 1980. X-ray diffraction procedures for clay mineral identification. In Brindley, G.W., and Brown, G. (Eds), Crystal Structures of Clay Minerals and Their X-ray Identification. Mineral. Soc. London Monogr., 5:305-359.

Chamley, H., 1989. Clay Sedimentology: Berlin (Springer Verlag).

Chantret, F., Desprairies, A., Douillet, P., Jacob, C., Steinberg, M., and Trauth, N., 1971. Révision critique de l'utilisation des méthodes thermiques en sédimentologie: cas des smectites (montmorillonites). Bull. Groupe Fr. Argiles, 23:141-172.

Clayton, J.L., and Swetland, P.J., 1978. Subaerial weathering of sedimentary organic matter. Geochim. Cosmochim. Acta, 42:305-312.

Coccioni, A., Nesci, O., Tramontana, M., Wezel, F.C., and Moretti, E., 1987. Descrizione di un livello-guida "radiolaritico-bituminoso-ittiolitico" alla base delle marne a fucoidi nell'Apennino umbro-marchigiano. Boll. Soc. Geol. Ital., 106:183-192.

Correia, M., and Maury, R.C., 1975. Effets thermiques, minéralogiques et chimiques de l'intrusion d'un dyke basaltique dans le Toarcien des Causses. Bull. Cent. Rech. Pau, 9:245-259.

Dean, W.E., Claypool, G.E., and Thiede, J., 1981. Origin of organic-carbonrich Mid-Cretaceous limestones, Mid-Pacific Mountains and southern Hess Rise. In Thiede, J., Vallier, T.L., et al., Init. Repts. DSDP, 62: Washington (U.S. Govt. Printing Office), 877-890.

Debrabant, P., Chamley, H., Deconinck, J.F., Récourt, P., and Trouiller, A., 1992. Clay sedimentology, mineralogy and chemistry of Mesozoic sediments drilled in the northern Paris Basin. Sci. Drill., 3:138-152.

Deconinck, J.F., 1992. Sédimentologie des argiles dans le Jurassique-Crétacé d'Europe occidentale et du Maroc [Habilit. thesis]. Lille Univ.

Deconinck, J.F., and Strasser, A., 1987. Sedimentology, clay mineralogy and depositional environment of Purbeckian green marls (Swiss and French Jura). Eclogae Geol. Helv., 80:753-772.

Deconinck, J.F., Strasser, A., and Debrabant, P., 1988. Formation of illitic minerals at surface temperatures in Purbeckian sediments (Lower Berriasian, Swiss and French Jura). Clay Miner., 23:91-103.

Deroo, G., Herbin, J.-P., Roucaché, J., Tissot, B., Albrecht, P., and Schaeffle, J., 1978. Organic geochemistry of some Cretaceous black shales from Sites 367 and 368; Leg 41, Eastern North Atlantic. In Lancelot, Y., Seibold, E., et al., Init. Repts. DSDP, 41: Washington (U.S. Govt. Printing Office), 865-873.

Didyk, B.M., Simoneit, B.R.T., Brassell, S.C., and Eglinton, G., 1978. Organic geochemical indicators of palaeoenvironmental conditions of sedimentation. Nature, 272:216-222.

Durand, B., and Monin, J.C., 1980. Elemental analysis of kerogens (C,H,O,N,S,Fe). In Durand, B. (Ed.), Kerogen: Insoluble Organic Matter from Sedimentary Rocks: Paris (Ed. Technip), 113-142.

Durand, B., and Nicaise, G., 1980. Procedures for kerogen isolation. In Durand, B. (Ed.), Kerogen Insoluble Organic Matter From Sedimentary Rocks: Paris (Ed Technip), 35-53.

Eberl, D.D., Srodon, J., and Northrop, H.R., 1986. Potassium fixation in smectite by wetting and drying. In Davis, J.A., and Hayes, K.F. (Eds.), Geochemical Processes at Mineral Surfaces. Am. Chem. Soc. Symp. Ser., 323:296-326.

Espitalié, J., Deroo, G., and Marquis, F., 1985a. La pyrolyse Rock-Eval et ses applications, Partie I. Rev. Inst. Fr. Pet., 40:563-579.

1985b. La pyrolyse Rock-Eval et ses applications, Partie II. Rev. Inst. Fr. Pet., 40:755-784.

, 1986. La pyrolyse Rock-Eval et ses applications, Partie III. Rev. Inst. Fr. Pet., 41:73-89.

Espitalié, J., Madec, M., and Tissot, B., 1980. Role of mineral matrix in kerogen pyrolysis: influence on petroleum generation and migration. AAPG Bull., 64:59-66.

Foster, C.B., Reed, J.D., and Wigander, R., 1989. Gloecapsomorpha prisca Zalessky, 1917. A new study, Part 1: Taxonomy, geochemistry and paleoecology. Geobios, 22:735-759. 
Gautier, D.L., 1986. Cretaceous shale from the Western Interior of North America: sulfur/carbon ratios and sulfur-isotope composition. Geology, $14: 225-228$.

Glikson, M., and Taylor, G.H., 1986. Cyanobacterial mats: major contributor to the organic matter in the Toolebuc oil shales. In Gravestock, D.I., Moore, P.S., and Pitt, G.M. (Eds.), Contributions to the Geology and Hydrocarbon Potential of the Eromanga Basin. Spec. Pub.-Geol. Soc. Aust., 273-286.

Goossens, H., de Leeuw, J.W., Schenk, P.A., and Brassell, S.C., 1984. Tocopherols as likely precursors of pristane in ancient sediment and crude oils. Nature, 312:440-442.

Holtzapffel, T., 1985. Les minéraux argileux: préparation, analyse diffractométrique et détermination. Publ. Soc. Geol. Nord, 12.

Inoue, A., Bouchet, A., Velde, B., and Meunier, A., 1989. Convenient technique for estimating smectite layer percentage in randomly interstratified illite/smectite minerals. Clays Clay Miner., 37:227-234.

Jenkyns, H.C., and Schlanger, S.O., 1981. Significance of plant remains in redeposited Aptian sediments, Hole 462A, Nauru Basin, to Cretaceous oceanic-oxygenation models. In Larson, R.L., and Schlanger, S.O., et al., Init. Repts. DSDP, 61: Washington (U.S. Govt. Printing Office), 557-562.

Kenig, F., 1991. Sédimentation, distribution et diagenèse de la matière organique dans un environnement carbonaté hypersalin, le système lagunesabkha d'Abu Dhabi (E.A.U.) [Ph.D. thesis]. Univ. d'Orleans, France.

Kenig, F., and Huc, A.Y., 1990. Incorporation of sulfur into Recent organic matter in a carbonate environment (Abu Dhabi, U.A.E.). In Orr, W.L., and White, C.M. (Eds.), Geochemistry of Sulfur in Fossil Fuels. Am. Chem. Soc. Symp. Ser., 429:170-185.

Kenig, F., Huc, A.Y., Purser, B.H., and Oudin, J.-L., 1990. Sedimentation, distribution and diagenesis of organic matter in a Recent carbonate environment, Abu Dhabi, UAE. Org. Geochem., 16:735-747.

Krumbein, W.E., Cohen, Y., and Shilo, M., 1977. Solar Lake (Sinai) 4. Stromatolitic cyanobacterial mats. Limnol. Oceanogr., 22:635-656.

Mélières, F., Deroo, G., and Herbin, J.-P., 1981. Organic-matter-rich and hypersiliceous Aptian sediments from western Mid-Pacific Mountains, Deep Sea Drilling Project Leg 62. In Thiede, J., Vallier, T.L., et al., Init. Repts. DSDP, 62: Washington (U.S. Govt. Printing Office), 903-915.

Moore, D.M., and Reynolds, R.C., Jr., 1989. X-ray Diffraction and the Identification and Analysis of Clay Minerals: Oxford (Oxford Univ. Press)

Nagel, U., and Schumann, D., 1981. X-ray mineralogy of sediments, Deep Sea Drilling project 62. In Thiede, J., Vallier, T.L., et al., Init. Repts. DSDP, 62: Washington (U.S. Govt. Printing Office), 529-535.

Newman, A.C.D., and Brown, G., 1987. The chemical constitution of clays. In Newman, A.C.D. (Ed.), Chemistry of Clays and Clay Minerals. Mineral. Soc. London Monogr., 6:1-128

Noël, D., Busson, G., Cornée, A., and Mangin, A.M., 1993. Les coccolithophoridés fossiles ne peuvent être considérées comme caractéristiques du seul environnement pélagique. Bull. Soc. Geol. Fr., 164:493-502.

Odin, G.S., and Matter, A., 1981. Die glauconarium origine. Sedimentology, 28:611-643

Orr, W.L., 1983. Comments on pyrolitic hydrocarbon yields in source rock evaluation. In Bjoroy, M., et al. (Eds.), Advances in Organic Geochemistry: New York (Wiley), 775-783.

Paterson, E., and Swaffield, R., 1987. Thermal analysis. In Wilson, M.J.A. (Ed.), A Handbook of Determinative Methods in Clay Mineralogy: New York (Chapman and Hall), 99-132.

Peters, K.E., 1986. Guidelines for evaluating petroleum source rock using programmed pyrolysis. AAPG Bull., 70:318-329.

Porrenga, D.H., 1968. Non-marine glauconitic illite in the Lower Oligocene of Aardeburg, Belgium. Clay Miner., 7:421-430.
Rateev, M.A., Timofeev, P.P., and Koporulin, V.I., 1981. Clay minerals in Mesozoic and Cenozoic sediments of Deep Sea Drilling Project Leg 62. In Thiede, J., Vallier, T.L., et al., Init. Repts. DSDP, 62: Washington (U.S. Govt. Printing Office), 537-544.

Reynolds, R.C., 1980. Interstratified clay minerals. In Brindley, G.W., and Brown, G. (Eds.), Crystal Structures of Clay Minerals and their X-Ray Identification. Mineral. Soc. London Monogr., 5:249-303.

Robinson, D., and Wright, V.P., 1987. Ordered illite-smectite and kaolinitesmectite: pedogenic minerals in a Lower Carboniferous paleosol sequence, South Wales. Clay Miner., 22:109-118.

Schaaf, A., 1981. Late Early Cretaceous radiolarians from Deep Sea Drilling Project Leg 62. In Thiede, J., Vallier, T.L., et al., Init. Repts. DSDP, 62: Washington (U.S. Govt. Printing Office), 419-470.

Schlanger, S.O., and Jenkyns, H.C., 1976. Cretaceous oceanic anoxic events: causes and consequences. Geol. Mijnbouw, 55:179-184.

Shipboard Scientific Party, 1993a. Site 865. In Sager, W.W, Winterer, E.L., Firth, J.V., et al., Proc. ODP, Init. Repts., 143: College Station, TX (Ocean Drilling Program), 111-180.

1993b. Site 866. In Sager, W.W., Winterer, E.L., Firth, J.V., et al., Proc. ODP, Init. Repts., 143: College Station, TX (Ocean Drilling Program), 181-271.

Sliter, W.V., 1989. Aptian anoxia in the Pacific Basin. Geology, 17:909-912.

Srodon, J., and Eberl, D.D., 1984. Illite. In Bailey, S.W. (Ed.), Micas. Reviews in Mineralogy, 13:495-544.

Stach, E., Mackowsky, M.-T., Teichmüller, M., Taylor, G.H., Chandra, D., and Teichmüller, R., 1982. Stach's Textbook of Coal Petrology (3rd ed.): Stutgart (Schweizerbart).

Taylor, G.H., Liu, S.Y., and Teichmüller, M., 1991. Bituminite-a TEM view. Int. J. Coal Geol., 18:71-85.

Teichmüller, M., and Ottenjann, K., 1977. Art und Diagenese von Liptiniten und lipoiden Stoffen in einem Erdölmuttergestein auf Grund fluoreszenzmikroskopischer Untersuchungen. Erdoel Kohle, 30:387-398.

ten Haven, H.L., de Leeuw, J.W., Rullkötter, J., and Sinninghe Damste, J.S., 1987. Restricted utility of the pristane/phytane ratio as a paleoenvironmental indicator. Nature, 330:641-643.

Thiede, J., Vallier, T.L., et al., 1981. Init. Repts. DSDP, 62: Washington (U.S. Govt. Printing Office).

Timofeev, P.P., and Bogolyubova, L.I., 1981. Cretaceous sapropelic deposits of Deep Sea Drilling Project Sites 463, 465, and 466. In Thiede, J., Vallier, T.L., et al., Init. Repts. DSDP, 62: Washington (U.S. Govt. Printing Office), 891-901.

Tissot, B., Durand, B., Espitalié, J., and Combaz, A., 1974. Influence of the nature and diagenesis of organic matter in the formation of petroleum. AAPG Bull., 58:499-506.

Tissot, B.P., 1984. Recent advances in petroleum geochemistry applied to hydrocarbon exploration. AAPG Bull., 68:545-563.

Tissot, B.P., and Welte, D.H., 1984. Petroleum Formation and Occurrence (2nd ed.): Heidelberg (Springer-Verlag).

Weissert, H., and Bréhéret, J.-G., 1991. A carbonate carbon-isotope record from Aptian-Albian sediments of the Vocontian trough (SE France). Bull. Soc. Geol. Fr., 162:1133-1140.

Date of initial receipt: 3 December 1993

Date of acceptance: 6 July 1994

Ms 143SR-220 

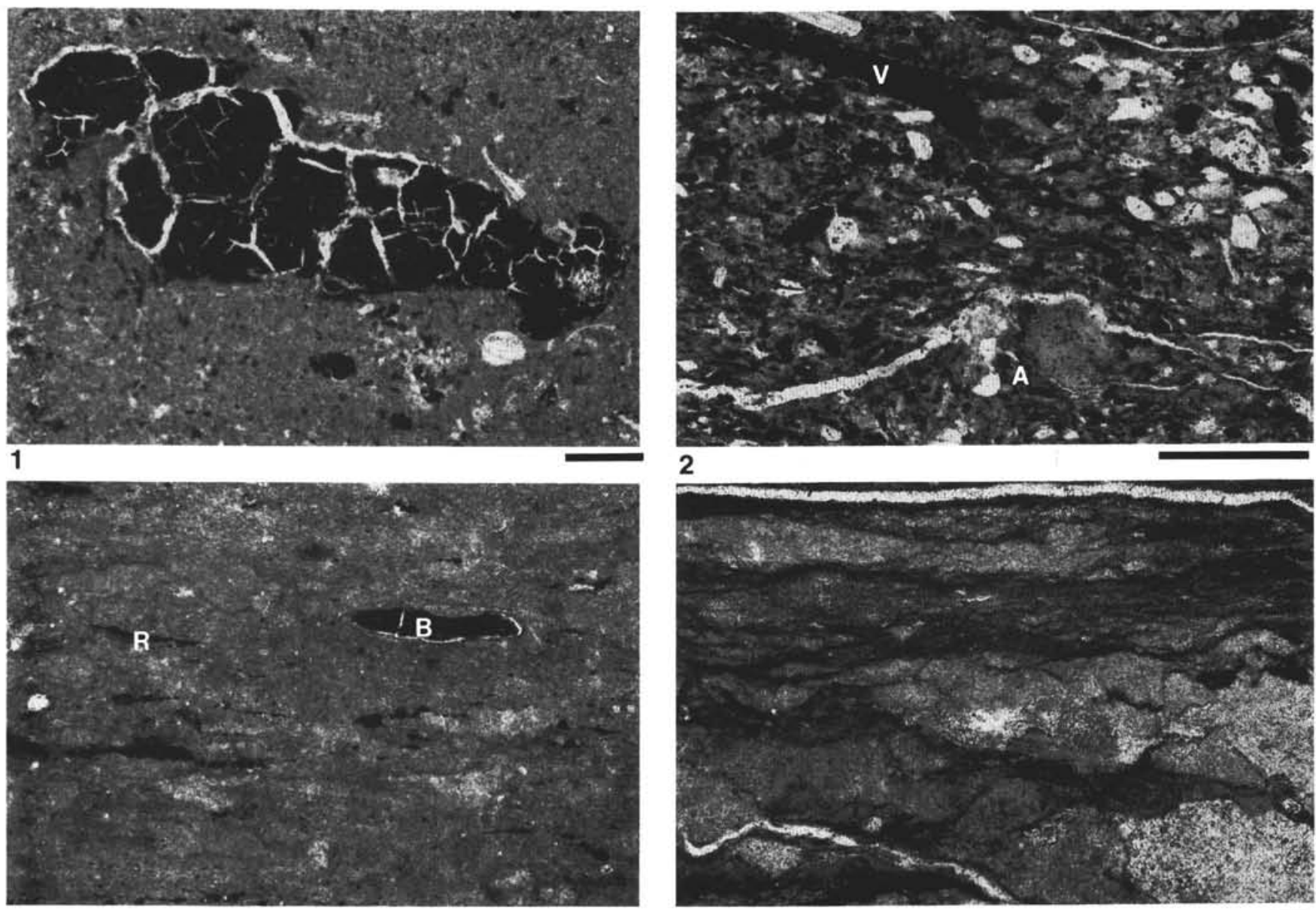

3
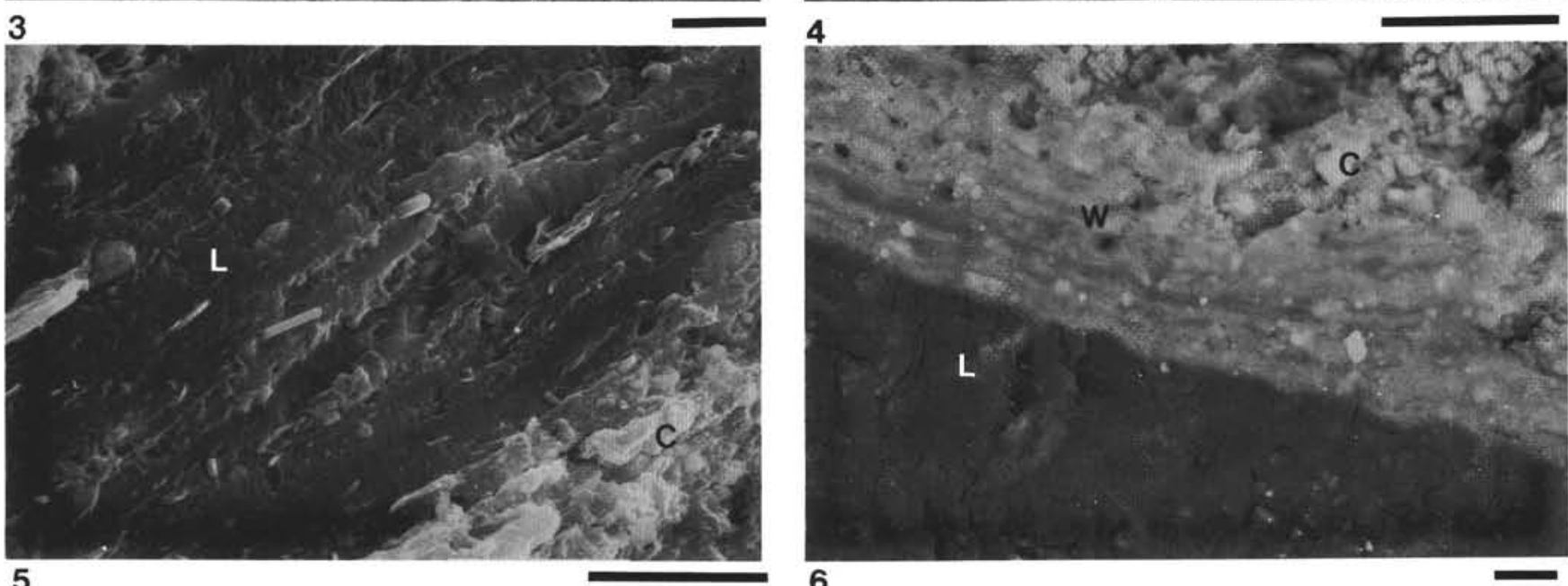

Plate 1. Photomicrographs of samples from Holes $865 \mathrm{~A}$ and $866 \mathrm{~A}$. Bar length is $0.2 \mathrm{~mm}$ for optical microscope view and $10 \mu \mathrm{m}$ for SEM view. 1. Sample 143-865A-90R-3, 81-83 cm. Higher-plant particles showing microcracks filled in by calcite. 2. Sample 143-865A-92R-2, 40-43 cm. Higher-plant derived particles (V) and intense yellow algal concentration (A). 3. Sample 143-866A-65R-1, 142-143 cm. Black (B) and red (R) dispersed organic particles in a mudstone facies. 4. Sample 143-866A-86R-3, 47-49 cm. Detail of a laminated wackestone showing abundant yellow to orange microbial mats. 5. Sample 143-866A-56R-1, 42-43 cm. SEM view of an organic laminae (L) in a coccolith-rich carbonate matrix (C). 6. Sample 143-866A-110R-2, 83-85 cm. Organomineral texture observed with a SEM in a back-scattered electron mode. The contact between the organic laminae (L) and the mineral matrix $(\mathrm{C})$ shows a weathered zone $(\mathrm{W})$ into the laminae. 


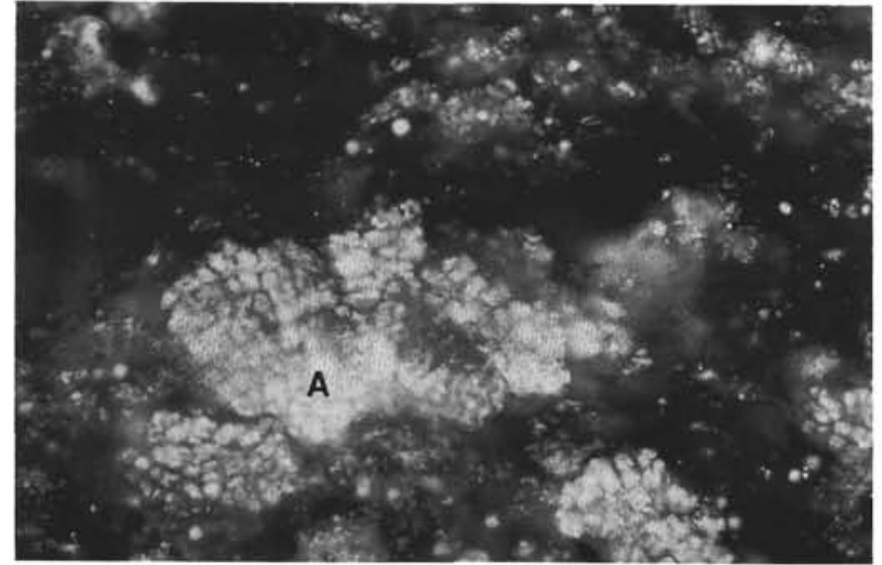

1

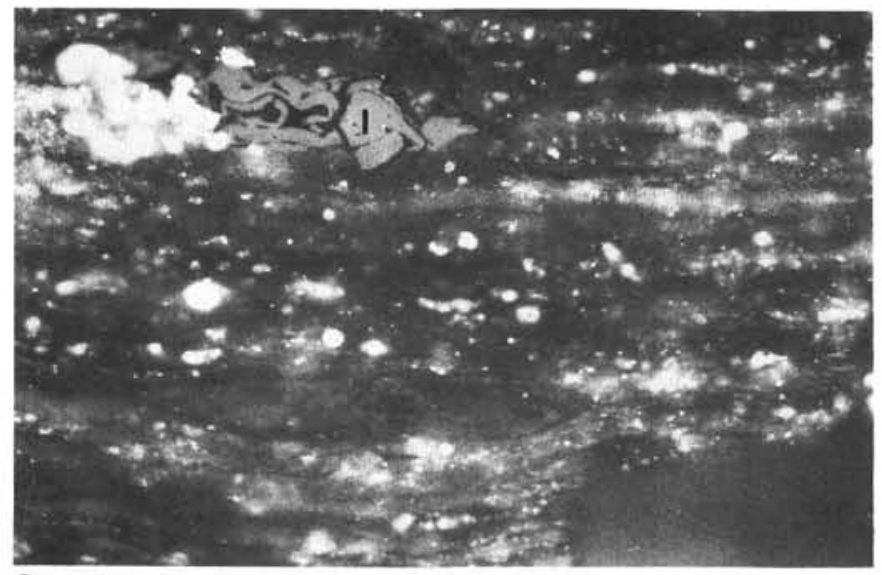

3

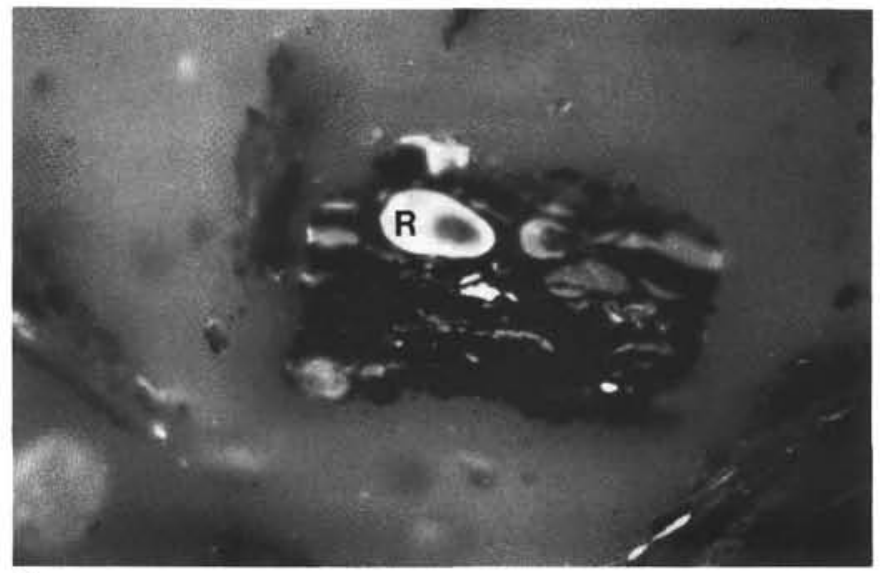

5

Plate 2. Photomicrographs of kerogen concentrates. Field width of all photomicrographs is $0.26 \mathrm{~mm}$. 1. Sample 143-865A-91R-5, 130-132 cm. Telalginite (A) derived most probably from Gloeocapsomorpha-related alga (reflected light). 2. Sample 143-865A-92R-2, 58-60 cm. Telalginite (A), vitrinite (V), and resinite (R) under blue light irradiation. Fluorescing telaginite is partly filled in with nonfluorescing pyrite. 3. Sample 143-866A-86R-2, 111-113 cm. Lamalginite, bituminite, and inertinite (I; reflected light). 4. Same field under blue light irradiation. Lamalginite and bituminite are strongly fluorescing, whereas inertinite is not fluorescing. 5. Sample 143-866A-89R-1, 98-99 cm (blue light irradiation). Nonfluorescing vitrinite with fluorescing resinite (R). 6. Sample 143-866A$111 \mathrm{R}-1,86-87 \mathrm{~cm}$ (blue light irradiation). Weak to very weak fluorescing bituminite.

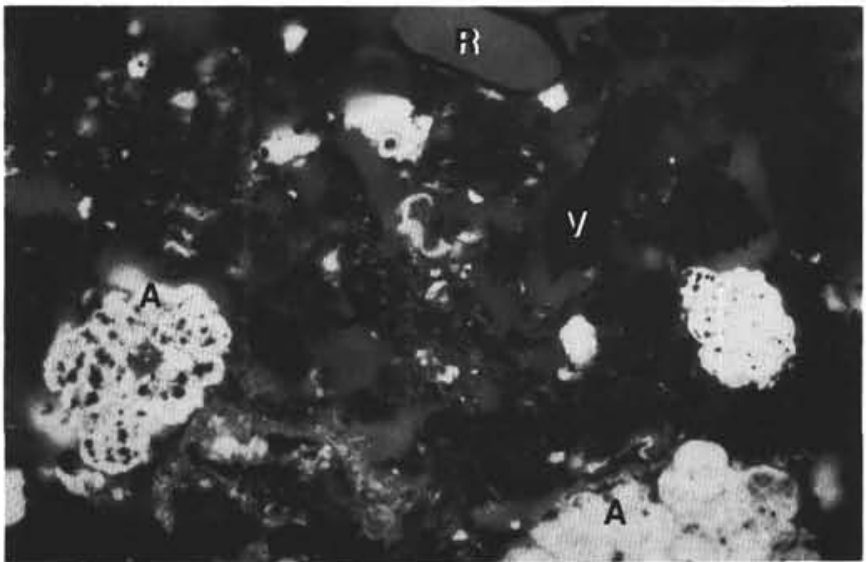

2

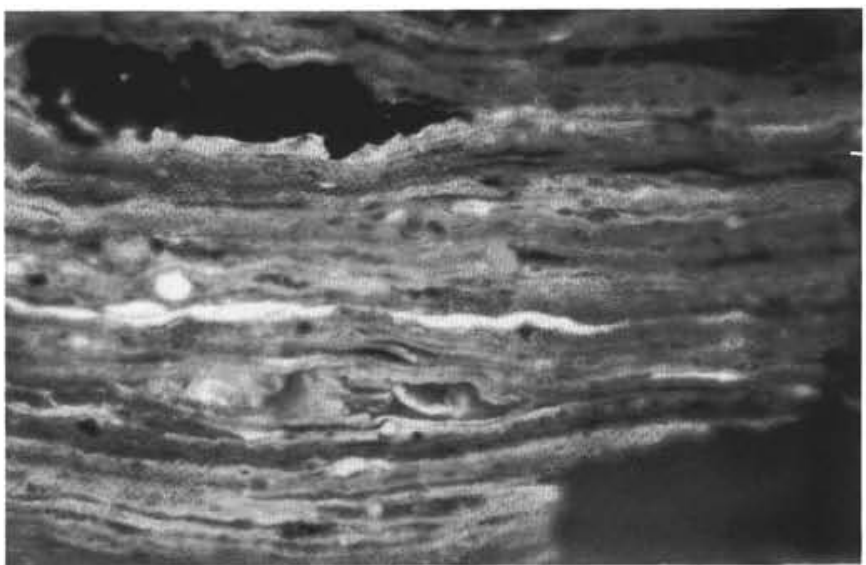

4

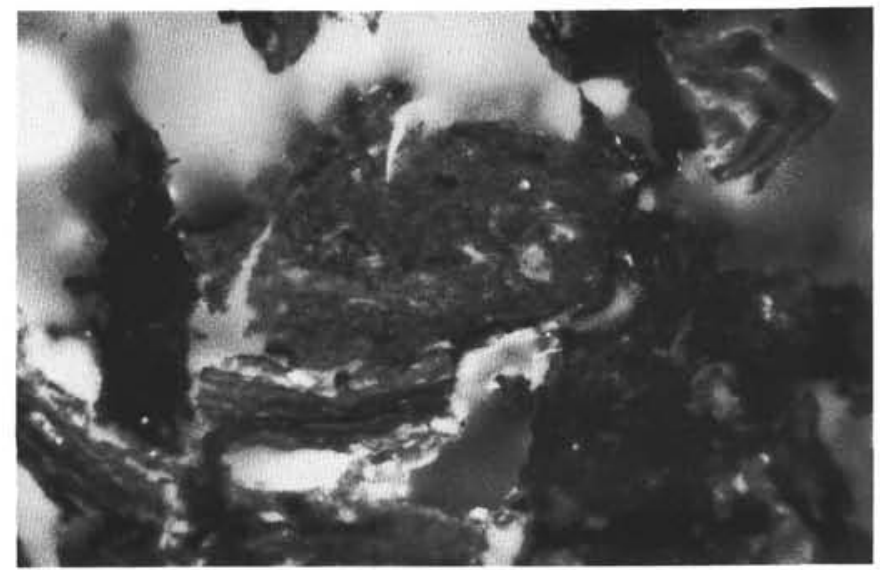

6 